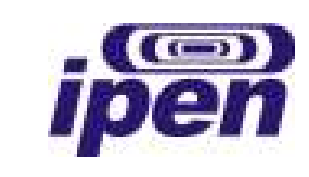

INSTITUTO DE PESQUISAS ENERGÉTICAS E NUCLEARES

Autarquia associada à Universidade de São Paulo

\title{
ESTUDOS DE RENATURAÇÃO DE PROTEÍNAS AGREGADAS UTILIZANDO ALTAS PRESSÕES HIDROSTÁTICAS
}

\author{
Natália Malavasi Vallejo
}

Orientadora: Dra. Ligia Ely Morganti Ferreira Dias

São Paulo

2013 


\title{
ipen
}

INSTITUTO DE PESQUISAS ENERGÉTICAS E NUCLEARES

Autarquia associada à Universidade de São Paulo

\section{ESTUDOS DE RENATURAÇÃO DE PROTEÍNAS AGREGADAS UTILIZANDO ALTAS PRESSÕES HIDROSTÁTICAS}

\author{
Natália Malavasi Vallejo \\ Tese apresentada como parte dos \\ requisitos para obtenção do Grau de \\ Doutor em Ciências na Área de \\ Tecnologia Nuclear - Aplicações.
}

Orientadora: Dra. Ligia Ely Morganti Ferreira Dias

São Paulo

2013 
Dedico este trabalho às pessoas mais importantes da minha vida: meus pais, Paulo e Beth, que confiaram no meu potencial para esta conquista. Não conquistaria nada se não estivessem ao meu lado. Obrigada, por estarem sempre presentes a todos os momentos, me dando carinho, apoio, incentivo, determinação, fé, e principalmente pelo Amor de vocês! 


\section{Agradecimentos}

Agradeço principalmente à Deus, por ter me dado a vida e estar sempre do meu lado, permitindo que com o passar do tempo eu possa evoluir principalmente como ser humano.

Aos meus pais, Paulo e Beth, por dedicarem a vida por mim, por fazer de mim quem sou hoje, e pelo amor incondicional que sempre me fez seguir no caminho que escolhi.

Ao meu irmão Diego e a minha tia Eliane, mesmo que de longe, participaram de mais esta conquista e tenho certeza que torceram todos os dias pelo meu sucesso. Muito Obrigada, Amo vocês!!

Ao Bruno, pelo apoio em tudo que faço, pela dedicação, paciência e amor durante todos esses anos.

À minha orientadora Ligia Ely Morganti Ferreira Dias, pela oportunidade de ser sua aluna, pela confiança depositada em mim e por compartilhar comigo seus conhecimentos e experiências profissionais.

Ao Prof. Dr. Patrick Jack Spencer, por toda a ajuda e conselhos na realização deste trabalho e por dividir comigo seus conhecimentos e experiências no laboratório durante todos esses anos.

Ao Dr. Carlos Bonafé, pela colaboração permitindo a utilização do sistema de pressão do Laboratório Termodinâmica de Protreínas da UNICAMP e a Juliana e Joelma pela ajuda na realização dos experimentos.

Ao Dr. Geraldo Santana Magalhães, pela doação do gene da eGFP.

Ao Dr. Shaker Chuck Farah, a Cristiane Guzzo, ao Maicon e ao Raphael pela doação dos genes das proteínas de Xac e pela ajuda na realização dos experimentos de purificação e atividade biológica destas proteínas. 
As amigas de trabalho, Laura, Daniella e Rosa, cada uma com o seu jeitinho aprendi que a convivência com as pessoas não é fácil, porém é impossível realizar o trabalho sozinha. Sem vocês o trabalho ficaria muito mais difícil, a cada uma o meu "muito obrigada"!!!

Às amigas que fiz no IPEN, Danielle, Keli, Larissa, Karina e Renata, pelas conversas, conselhos, saidinhas, almoços e tardes de risadas que tivemos durante todos esses anos de amizade. Muito Obrigada!

Aos amigos que fiz no IPEN, Alberto (Troxinha), Mariana, Tamara, Rodrigo, Vincent, Eliza, Bia, Fernanda, Bruno, Ed Carlos, Allison, Daniele e a tantos outros.

A todos os funcionários do Centro de Biotecnologia do IPEN, que cada um em seu setor fez parte da realização deste trabalho, Rute, Arlete, Zé Maria, Junqueira, João, Sr. Longino, Sandra, Beth, Néia, Marisa, Gislaine, sem vocês não seria possível.

Às amigas, Renata (Fuba), Flavinha (Florzinha) e Claudinha (Japa) pela amizade, pelo companheirismo, pelo apoio, pela paciência, pelas risadas e choros e por todos esses anos inesquecíveis que passamos juntas. Muito Obrigada pela amizade!!

Às amigas, Bianca, Giovanna, Thaís, Gabi e Thalita, que com o passar do tempo cada uma tomou um caminho diferente e não importa a distância e o tempo que passamos sem nos falar ou nos ver, que a amizade, o carinho e o amor continuam os mesmos, e tenho certeza que torcem pela minha felicidade. Muito Obrigada!!!

Ao CNPq e a FAPESP pelo apoio financeiro. 
"Só depois que o passado passou é que a gente descobre o quanto ele foi bom enquanto durou" Eno Teodoro Wanke 


\title{
ESTUDOS DE RENATURAÇÃO DE PROTEÍNAS AGREGADAS UTILIZANDO ALTAS PRESSÕES HIDROSTÁTICAS
}

\author{
NATÁLIA MALAVASI VALLEJO
}

\section{RESUMO}

No presente trabalho estudamos a renaturação sob alta pressão hidrostática de uma forma mutante da proteína verde fluorescente (enhanced GFP, eGFP), a qual somente emite fluorescência característica quando enovelada na sua forma nativa. A abordagem do presente estudo foi focada no controle da bioatividade da proteína recombinante, a fluorescência, como alternativa à determinação de solubilidade da proteína, fator que não é um indicador ideal de enovelamento proteico adequado. A ação da alta pressão na solubilização dos corpos de inclusão $(\mathrm{Cl})$ de eGFP produzidos em bactérias $E$. coli recombinantes e no enovelamento da proteína foi estudada. A compressão dos $\mathrm{Cl}$ de eGFP em 2,4 kbar durante 30 minutos promoveu a dissociação dos agregados. No entanto, a incubação nesta condição não favoreceu o enovelamento da eGFP. O processo de renaturação foi avaliado em diversas condições de descompressão após a dissociação em 2,4 kbar. Durante a descompressão gradual, o aumento da fluorescência foi obtido em pressões que variaram entre a pressão atmosférica e $1,38 \mathrm{kbar}$. Os níveis mais elevados de fluorescência de eGFP foram obtidos por incubação durante várias horas a níveis de pressão entre 0,35 e 0,69 kbar. Esta condição de pressão se mostrou favorável à renaturação de eGFP e é possível que também possa ser utilizada para favorecer o enovelamento de outras proteínas monoméricas. Ainda utilizando a eGFP como modelo, verificamos que os $\mathrm{Cl}$ desta proteína produzidos por bactérias cultivadas em menor temperatura $\left(37^{\circ} \mathrm{C}\right)$ possuem maior quantidade de proteína recombinante apresentando a fluorescência característica em $509 \mathrm{~nm}$, ou seja, na sua forma nativa, do que os $\mathrm{Cl}$ expressos em temperaturas mais elevadas $\left(42^{\circ} \mathrm{C}\right.$ e $\left.47^{\circ} \mathrm{C}\right)$. A análise realizada por espectroscopia de infravermelho (FT-IR) também demonstrou que os $\mathrm{Cl}$ produzidos em temperaturas mais brandas possuem maior grau de estruturas secundárias semelhantes às da proteína na sua forma nativa. Além disso, os $\mathrm{Cl}$ 
produzidos a $37^{\circ} \mathrm{C}$ também são mais facilmente solubilizados pela ação da alta pressão do que aqueles produzidos em maior temperatura. Conforme esperado, a renaturação da eGFP a partir de $\mathrm{Cl}$ produzidos a $37^{\circ} \mathrm{C}$ foi 25 vezes mais eficiente do que a obtida utilizando $\mathrm{Cl}$ produzidos a $47^{\circ} \mathrm{C}$. No presente estudo demonstramos também que a dissociação dos agregados exercida pela ação da alta pressão (2,4 kbar) pode ser amplificada quando em associação com a incubação em baixa temperatura $\left(-9^{\circ} \mathrm{C}\right)$ e que a combinação destas duas propriedades físicas eleva a solubilização dos agregados em $\mathrm{Cl}$, com a consequente elevação dos rendimentos de renaturação de eGFP. Mostramos ainda no presente estudo que a cinética de renaturação de eGFP em 0,69 kbar é proporcional à temperatura de incubação (entre $10^{\circ} \mathrm{C}$ e $50^{\circ} \mathrm{C}$ ). $\mathrm{O}$ nível mais elevado de fluorescência foi obtido quando a renaturação de eEGP foi realizada a $20^{\circ} \mathrm{C}$. A taxa de maturação do cromóforo da eGFP é mais fortemente afetada pela temperatura do que a taxa de enovelamento da proteína. Em conclusão, a temperatura de produção dos $\mathrm{Cl}$, a temperatura de dissociação dos agregados e a temperatura de enovelamento podem afetar muito o rendimento e a cinética da renaturação de eGFP em alta pressão.

Os resultados do presente estudo podem abrir novas perspectivas para melhorias no processo de enovelamento de proteínas a partir de $\mathrm{Cl}$ utilizando alta pressão. Também neste trabalho descrevemos a renaturação das proteínas de Xac, PilB e os produtos dos genes XAC2810 e XAC3272 nunca antes obtidas na forma solúvel. Os rendimentos de solubilização destas três proteínas foram muito altos, entre $75 \%$ e $89 \%$. A proteína PilB renaturada em alta pressão apresentou atividade ATPasica elevada, o que nunca antes foi demonstrado para a PilB de Xac. 


\title{
RENATURATION STUDIES OF AGGREGATE PROTEINS USING HIGH HYDROSTATIC PRESSURE
}

\author{
NATÁLIA MALAVASI VALLEJO
}

\begin{abstract}
In the present work we studied the refolding under high hydrostatic pressure of a mutant form of the green fluorescent protein (eGFP), which only emits the green characteristic fluorescence when in the native folded state. The approach of the present study was focused on controlling the bioactivity of the recombinant protein, the fluorescence, as an alternative for the determination of protein solubility, which is not an ideal indicator of proper protein folding. We studied the action of high pressure in the solubilization of the inclusion bodies (IB) of eGFP produced in bacteria $E$. coli and in the folding of this protein. The compression of a suspension of eGFP IB at 2.4 kbar for 30 minutes promoted dissociation of aggregates. However, the eGFP folding, monitored by the fluorescence at $509 \mathrm{~nm}$, does not occur in this pressure level. The process of eGFP refolding was evaluated under various decompression conditions after dissociation of the IB at 2.4 kbar. During the gradual decompression, the increase in fluorescence was achieved at pressures ranging between atmospheric pressure and $1.38 \mathrm{kbar}$. The higher levels of eGFP fluorescence were obtained by incubation for several hours at pressure levels between 0.35 and $0.69 \mathrm{kbar}$. It is possible that the pressure condition that proved favorable for refolding of eGFP can also be used to favor the folding of other monomeric proteins. Using eGFP as a model, we also found that the IB produced by bacteria grown in a relatively low temperature $\left(37^{\circ} \mathrm{C}\right)$ is more fluorescent, presenting a higher amount of recombinant protein with the characteristic fluorescence at $509 \mathrm{~nm}$, i.e., in its native form, than the IB expressed at higher temperatures $\left(42^{\circ} \mathrm{C}\right.$ and $\left.47^{\circ} \mathrm{C}\right)$. The analysis by infrared spectroscopy (FT-IR) also demonstrated that the IB produced at milder temperatures have a higher degree of secondary structure similar to the protein in its native form. Furthermore, the IB produced at $37^{\circ} \mathrm{C}$ are also more readily solubilized by the action of high pressure than those produced at the higher temperatures. As
\end{abstract}


expected, the folding of eGFP from IB produced at $37^{\circ} \mathrm{C}$ was 25 times more efficient than that obtained using IB produced at $47^{\circ} \mathrm{C}$. In this study we demonstrated that the dissociation of aggregates exerted by the action of high pressure $(2.4 \mathrm{kbar})$ can be amplified by combination with incubation at low temperature $\left(-9^{\circ} \mathrm{C}\right)$ and the association of these two physical properties can be used to increase the solubilization of the aggregates in IB, with a consequent increase in the yield of eGFP refolding. In the present study we also showed that the kinetics of refolding of eGFP is proportional to temperature $\left(10^{\circ} \mathrm{C}-50^{\circ} \mathrm{C}\right)$. The higher level of fluorescence was obtained when the refolding of eGFP was performed at $20^{\circ} \mathrm{C}$. The rate of maturation of the eGFP chromophore is more strongly affected by temperature than the rate of folding of the protein. In conclusion, the temperature of production of IB, the temperature of dissociation of aggregates and the folding temperature can greatly affect the yield and kinetics of refolding of eGFP at high pressure.

The results of this study may open new perspectives for improvements in the process of protein folding from IB using high pressure. In this paper we also describe the refolding of the proteins of Xac, PilB and the gene products XAC2810 and XAC3272, which have never before been achieved in soluble form. The yields of solubilization/refolding of these three proteins were very high, between $75 \%$ and 89\%. The protein PilB refolded at high pressure presented high ATPase activity, which has never been shown for the PilB of Xac. 


\section{ÍNDICE DE TABELAS}

Tabela 1. Exemplos de organismos bioluminescentes (Chalfie 1998). 12

Tabela 2. Antibióticos utilizados para expressão das proteínas e genes alvos. 29

Tabela 3. Esquemas de Compressão e Descompressão. 31

Tabela 4. Rendimento de renaturação de eGFP em alta pressão hidrostática. 51

Tabela 5. Taxas de aquisição de fluorescência 62 


\section{ÍNDICE DE FIGURAS}

Figura 1. Microscopia eletrônica de varredura (MEV) dos $\mathrm{Cl}$ do fator estimulador de colônias granulocitárias humano (G-CSF).............................................. 2

Figura 2. Etapas para a recuperação de proteínas solúveis a partir de $\mathrm{Cl}$............ 4

Figura 3. Efeitos da alta pressão hidrostática ocasionando a dissociação de proteínas oligoméricas e a desnaturação das subunidades

Figura 4. Aequoria victoria.......................................................................... 13

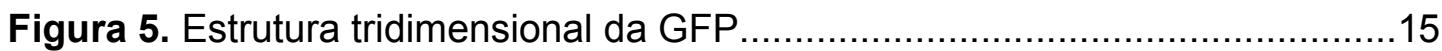

Figura 6. Mecanismo para a maturação do cromóforo. ..................................15

Figura 7. Citros mostrando sintomas de Cancro cítrico....................................19

Figura 8. Vista aérea da erradicação de árvores de laranja em um raio de 30 metros em relação ao centro do foco da contaminação por Xac.........................19

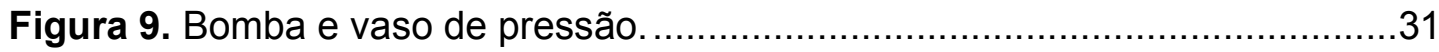

Figura 10. Espectrofluorímetro acoplado a uma célula de pressão, gerador de

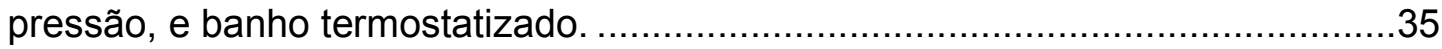

Figura 11. Cubeta de quartzo selada com tampa flexível de silicone...................35

Figura 12. Efeito da alta pressão na dissociação de Cl de eGFP (EL e MEV)....41

Figura 13. Intensidade de Fluorescência de eGFP renaturada sob diferentes métodos de compressão e descompressão.

Figura 14. Intensidade de Fluorescência de eGFP a partir de suspensões de Cl submetidos a 2,4 kbar de pressão utilizando diferentes pressões intermediárias na renaturação. .45

Figura 15. Renaturação e solubilização dos Cl de eGFP. 48

Figura 16. Espectros na região de amida I das amostras liofilizadas, eGFP nativa purificada e $\mathrm{Cl}$ produzidos em diferentes temperaturas.

Figura 17. Intensidade de fluorescência específica de suspensões de Cl de eGFP produzidos em diferentes temperaturas. .55

Figura 18. Dissociação de suspensões de Cl de eGFP pela ação de alta pressão e monitorado pelo EL. .56

Figura 19. Intensidade de fluorescência da eGFP renaturada a partir de $\mathrm{Cl}$ produzidos em diferentes temperaturas. 
Figura 20. Efeito de alta pressão e baixa temperatura na dissociação dos $\mathrm{Cl}$ de eGFP e na renaturação da proteína. .59

Figura 21. Cinética de renaturação da eGFP a 0,69 kbar. 62

Figura 22. Cinética de fluorescência de suspensões de $\mathrm{Cl}$ e proteína nativa, submetidos a 2,4 kbar, despressurização para 0,69 kbar e incubação em diferentes temperaturas.

Figura 23. Efeito de diferentes concentrações de $\mathrm{Gnd} \mathrm{HCl}$ na dissociação dos $\mathrm{Cl}$ produzidos em diferentes temperaturas de cultivo. 64

Figura 24. Rendimentos de solubilização das suspensões de $\mathrm{Cl}$ submetidas à renaturação em alta pressão. Seleção de proporção de glutationas reduzida/oxidada. 66

Figura 25. Rendimentos de solubilização das suspensões de $\mathrm{Cl}$ submetidas à renaturação em alta pressão. Seleção de proporção das concentrações de Gnd $\mathrm{HCl}$.

Figura 26. Rendimentos de solubilização das suspensões de $\mathrm{Cl}$ submetidas à renaturação em alta pressão. Presença de diferentes aditivos. 69

Figura 27. Rendimentos de solubilização das suspensões de $\mathrm{Cl}$ submetidas à renaturação em alta pressão. Efeito de diferentes métodos de compressão e descompressão. .72

Figura 28. Cromatografia em coluna de exclusão molecular (Superdex 200) das proteínas solúveis de Xac. 74 


\section{Lista de Abreviaturas}

$\begin{array}{ll}\text { A } & \text { Absorbância } \\ \text { aa } & \text { Aminoácidos } \\ \text { bis-ANS } & \text { 4,4-dianilino-1,1-binaftil-5,5-sulfonato } \\ \text { BSA } & \text { Albumina bovina sérica } \\ \text { CI } & \text { Corpos de inclusão } \\ \text { D.O. } & \text { Densidade óptica } \\ \text { Da } & \text { Daltons } \\ \text { DTT } & \text { 1,4-ditiotreitol } \\ \text { E. coli } & \text { Escherichia coli } \\ \text { EDTA } & \text { Ácido etilenodiamino tetra-acético } \\ \text { eGFP } & \text { Enhanced green fluorescent protein } \\ \text { EL } & \text { Espalhamento de luz } \\ \text { FT-IR } & \text { Espectroscopia de infravermelho } \\ \text { g } & \text { Aceleração da gravidade } \\ \text { Gdn HCl } & \text { Hidrocloreto de guanidina } \\ \text { GFP } & \text { Green fluoroscence protein } \\ \text { GSH } & \text { Glutationa reduzia } \\ \text { GSSG } & \text { Glutationa oxidada } \\ \text { IPTG } & \text { Isopropil, } \beta \text {-D-tiogalactopiranosídeo } \\ \text { L-Arg } & \text { L-Arginina } \\ \text { MEV } & \text { Microscopia eletrônica de varredura } \\ \text { NaCl } & \text { Cloreto de Sódio } \\ \text { PEG } & \text { Polietilenoglicol } \\ \text { SDS } & \text { Dodecil sulfato de sódio } \\ \text { SDS-PAGE } & \text { eletroforese em gel de poliacrilamida } \\ \text { Tris } & \text { Tris(hidroximetil)aminometano } \\ \text { Tween 20 } & \text { Polioxietileno sorbitol monolaureato } \\ \text { Xac } & \text { Xanthomonas axonopodis pv citri } \\ & \end{array}$




\section{SUMÁRIO}

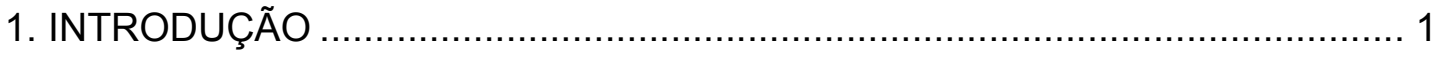

1.1. Expressão de proteínas recombinantes.............................................. 1

1.2. Processos Clássicos de Renaturação .................................................... 4

1.2.1. Renaturação de proteínas agregadas em $\mathrm{Cl}$ utilizando altas pressões

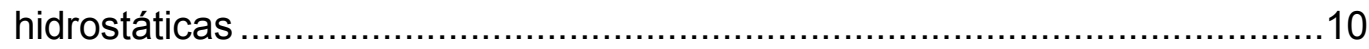

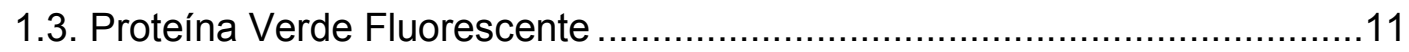

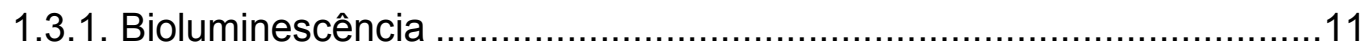

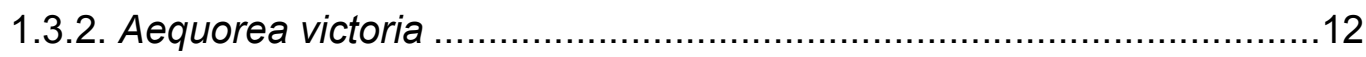

1.3.3. Proteína verde fluorescente selvagem (GFP) e "Enhanced" GFP

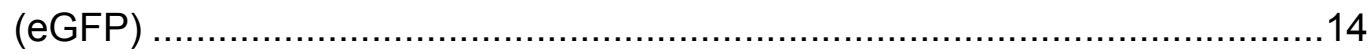

1.4. Proteínas de Xanthomonas axonopodis pv citri .......................................17

1.4.1. Papel do cancro cítrico na economia brasileira ...................................17

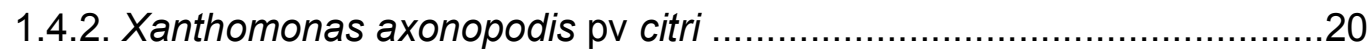

1.4.3. Genômica Funcional e Proteômica .......................................................20

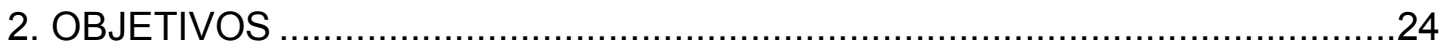

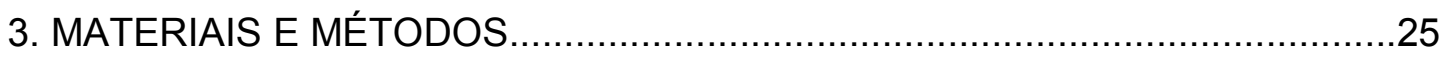

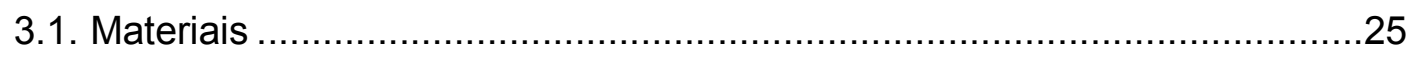

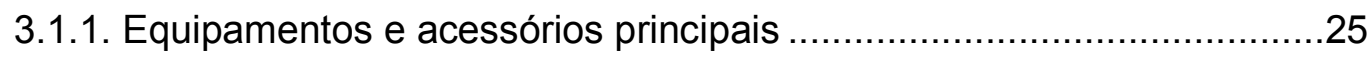

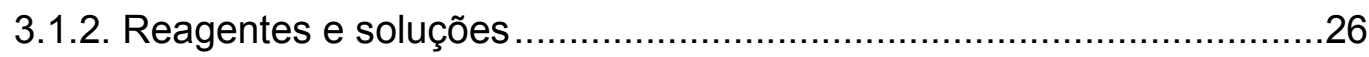

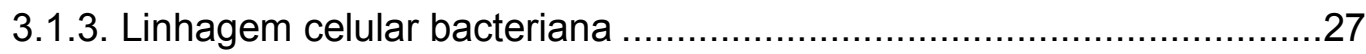

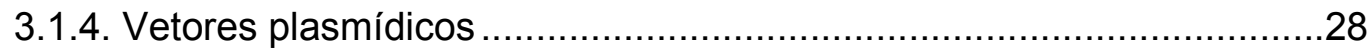

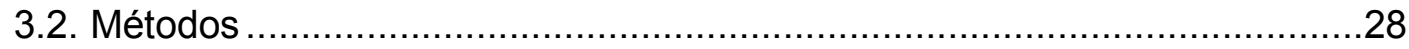

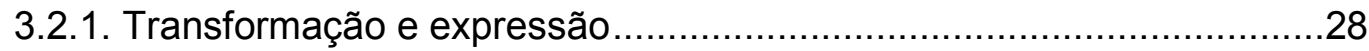

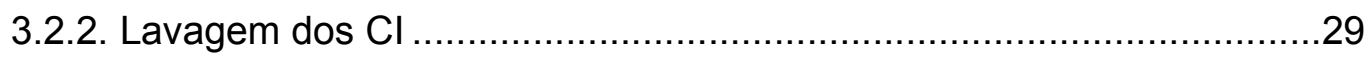

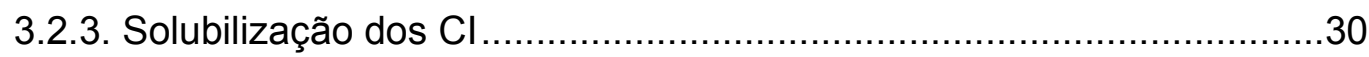

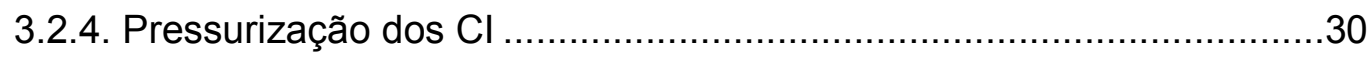

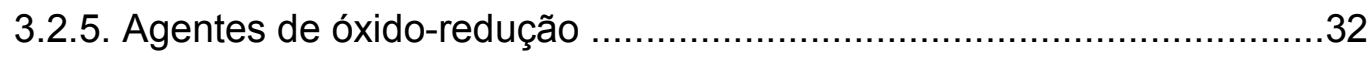

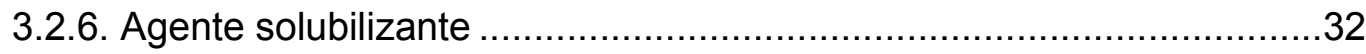

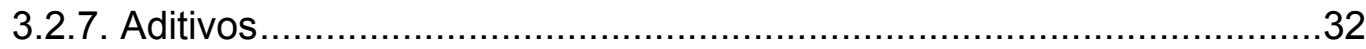

3.2.8. Eletroforese em Gel de Poliacrilamida (SDS-PAGE) ..........................33

3.2.9. Medidas de fluorescência e de espalhamento de luz (EL) ................... 34 
3.2.10. Dissociação dos $\mathrm{Cl}$ sob alta pressão hidrostática e temperaturas negativas .35

3.2.11. Microscopia eletrônica de varredura (MEV) 36

3.2.12. Espectroscopia de infravermelho (FT-IR). 36

3.2.13. Purificação por cromatografia de afinidade por metais imobilizados..37

3.2.14. Cálculo das taxas de constantes de aquisição de fluorescência.........37

3.2.15. Caracterização das proteínas solúveis PilB e produtos dos genes XAC2810 e XAC3272 por cromatografia de exclusão molecular

3.2.16. Análise de atividade biológica das proteínas renaturadas sob alta

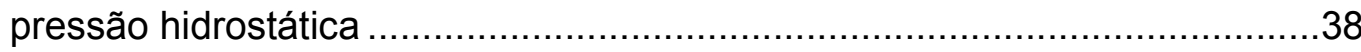

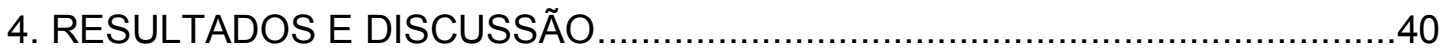

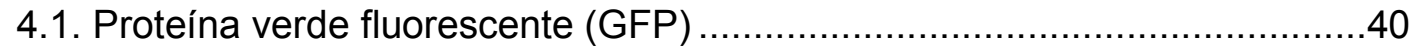

4.1.1. Dissociação dos $\mathrm{Cl}$ utilizando alta pressão hidrostática .....................40

4.1.2. Renaturação de $\mathrm{Cl}$ de eGFP sob alta pressão hidrostática .42

4.1.3. Estados renaturados e não renaturados permanecem solúveis após a descompressão. 46

4.1.4. A presença de $\mathrm{Gdn} \mathrm{HCl}$ desfavorece a renaturação de eGFP. 50

4.1.5. Influência da temperatura de expressão na estrutura secundária da eGFP nos $\mathrm{Cl}$

4.1.6. A fluorescência dos $\mathrm{Cl}$ depende da temperatura de cultivo das bactérias

4.1.7. Efeito de pressão e temperatura na dissociação dos agregados e na renaturação de eGFP sob alta pressão hidrostática

4.1.8. Cinética de renaturação da eGFP em diferentes temperaturas sob alta pressão

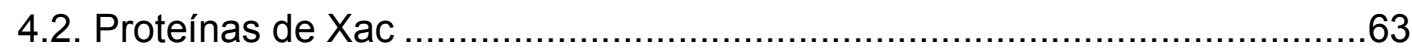

4.2.1. Seleção da temperatura de cultivo dos $\mathrm{Cl}$.

4.2.2. Efeito das diferentes proporções de glutationas reduzida/oxidada na solubilização das proteínas .

4.2.3. Efeito de diferentes concentrações de $\mathrm{Gdn} \mathrm{HCl}$ na solubilização dos $\mathrm{Cl}$ sob pressão. 66

4.2.4. Efeito de diferentes aditivos na solubilização dos $\mathrm{Cl}$ sob pressão. .68 4.2.5. Efeito de diferentes métodos de compressão e descompressão na solubilização e renaturação de $\mathrm{Cl}$. 
4.2.6. Caracterização das proteínas de Xac por cromatografia de exclusão

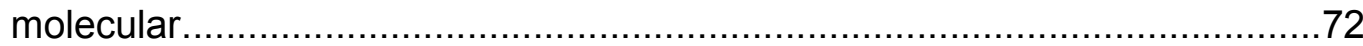

4.2.7. Análise de atividade biológica das proteínas de Xac renaturadas sob alta pressão hidrostática ...................................................................... 75

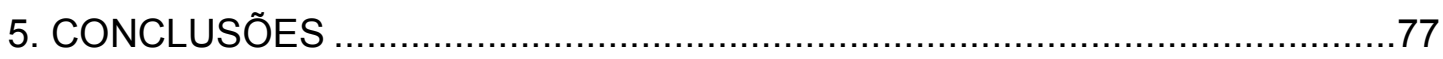

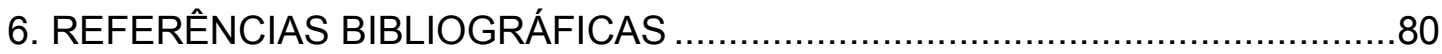




\section{INTRODUÇÃO}

\subsection{Expressão de proteínas recombinantes}

A produção de proteínas recombinantes tornou-se uma ferramenta muito valiosa para a pesquisa e a terapia com proteínas de interesse, essencial para a indústria biotecnológica, oferecendo suporte para a expansão da pesquisa biológica moderna, incluindo a genômica estrutural e a proteômica (Ventura and Villaverde 2006; Fahnert 2012). O sistema de expressão de proteínas heterólogas não glicosiladas mais comumente empregado utiliza a bactéria Escherichia coli como hospedeira. Este sistema é amplamente difundido devido à facilidade e baixo custo de cultivo das bactérias em condições laboratoriais, pela alta reprodutibilidade e em muitos casos pela abundância de produção das proteínas de interesse. No entanto, ao expressar proteínas recombinantes em bactérias, um dos efeitos secundários mais comuns é a formação de corpos de inclusão (Cl) (Baneyx and Mujacic 2004; Liovic, Ozir et al. 2012). A agregação das cadeias polipeptídicas como $\mathrm{Cl}$ pode se apresentar como um problema para a biotecnologia, dificultando a produção e a comercialização de muitas proteínas de interesse (Fahnert, Lilie et al. 2004).

Vários sistemas de expressão e condições de cultivo foram aprimorados com o objetivo de evitar a formação de $\mathrm{Cl}$. Contudo, a formação destes agregados proteicos ainda é muito comum e muitas vezes inevitável (Hartley and Kane 1988). Apesar da produção dos $\mathrm{Cl}$ ser considerada, de modo geral, indesejada, sua formação pode ser vantajosa. Os principais benefícios associados aos $\mathrm{Cl}$ são: produção de elevados níveis de proteínas, baixo custo, homogeneidade da proteína alvo, resistência à proteólise e como resultado, baixos níveis de degradação da proteína expressa e fácil isolamento e purificação. No caso da proteína de interesse ser tóxica para as células hospedeiras, a produção em $\mathrm{Cl}$ se torna praticamente a única opção viável de expressão (Clark 2001; Singh and Panda 2005).

A formação de $\mathrm{Cl}$ é um processo complexo e depende das condições de cultivo e do tipo de expressão das proteínas. Alguns fatores envolvidos no processo de agregação incluem: alta concentração local de proteína sintetizada; 
acúmulo de proteínas com a conformação completa ou parcialmente incorreta; processo de renaturação proteica incorreto; ausência de modificações póstraducionais necessárias para obter a solubilidade de algumas proteínas eucarióticas e inibição da formação de pontes dissulfeto nativas no ambiente redutor da bactéria (Fahnert, Lilie et al. 2004; Upadhyay, Murmu et al. 2012). Os $\mathrm{Cl}$ citoplasmáticos (figura 1) são estruturas ovóides ou cilíndricas com diâmetros que variam de 0,5 a $1,3 \mu \mathrm{m}$ e maior densidade $(\sim 1,3 \mathrm{mg} / \mathrm{ml})$ do que muitos componentes celulares. $\mathrm{O}$ fato de os $\mathrm{Cl}$ serem insolúveis facilita a sua separação dos outros componentes celulares por centrifugação e lavagens após o rompimento celular. Estas estruturas são altamente hidratadas, possuem uma arquitetura porosa e em geral são relativamente puras (Carrio, Cubarsi et al. 2000; Singh and Panda 2005). O tamanho dos agregados bem como as suas outras propriedades físicas e estruturais depende das condições de cultura e de indução da expressão nas bactérias hospedeiras (Margreiter, Messner et al. 2008; Margreiter, Schwanninger et al. 2008).

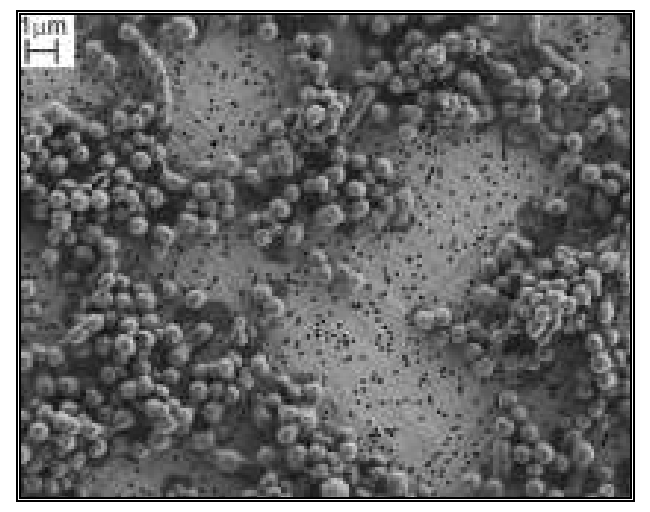

Figura 1. Microscopia eletrônica de varredura (MEV) dos $\mathrm{Cl}$ do fator estimulador de colônias granulocitárias humano (G-CSF). Retirado de Peternel, Grdadolnik et al. 2008.

Até recentemente as proteínas dos $\mathrm{Cl}$ eram consideradas como totalmente inativas. No entanto, o conhecimento atual sobre $\mathrm{Cl}$ evoluiu e hoje em dia se reconhece que proteínas agregadas em $\mathrm{Cl}$ não são necessariamente inativas (de Groot and Ventura 2006). Por meio de espectroscopia de infravermelho (FT-IR) se demonstrou que as proteínas nos $\mathrm{Cl}$ possuem estruturas secundárias semelhantes àquelas das proteínas em seu estado nativo (Ami, Natalello et al. 
2006). Além disso, dados recentes indicam a presença de certa porcentagem de proteínas apresentando estruturas terciárias com conformação nativa em $\mathrm{Cl}$, fato de grande importância para a produção de proteínas recombinantes, pois sugere que as proteínas podem ser liberadas dos $\mathrm{Cl}$ em um estado funcional, desde que se utilizem condições que desarranjem a rede de contatos intermoleculares sem desnaturarem as estruturas nativas que estão embebidas nestes agregados (de Groot and Ventura 2006).

$\mathrm{O}$ fato de a atividade biológica das proteínas nos $\mathrm{Cl}$ poder chegar a quase $100 \%$ possibilitou inclusive a utilização dessas proteínas estruturadas e biologicamente ativas como uma fonte adequada de enzimas para o uso direto em biocatálise (Tokatlidis, Dhurjati et al. 1991; Nahalka and Patoprsty 2009).

A estratégia geral para recuperar proteínas nativas a partir de $\mathrm{Cl}$ envolve três etapas: isolamento e lavagem dos $\mathrm{Cl}$, solubilização dos agregados proteicos e enovelamento das proteínas solubilizadas (figura 2). As células contendo os $\mathrm{Cl}$ são geralmente rompidas através de uma combinação de métodos químicos, mecânicos e enzimáticos. A suspensão restante é então centrifugada para o isolamento das proteínas solúveis da fração insolúvel e alguns passos de lavagens são realizados para a remoção de proteínas de membrana e outros contaminantes dos $\mathrm{Cl}$. Uma variedade de métodos pode ser utilizada para a solubilização e renaturação dos $\mathrm{Cl}$, contudo não há um método universal para a renaturação de todas as proteínas. A renaturação de proteínas a partir de $\mathrm{Cl}$ frequentemente requer um extensivo processo de tentativa e erro (Clark 2001). 


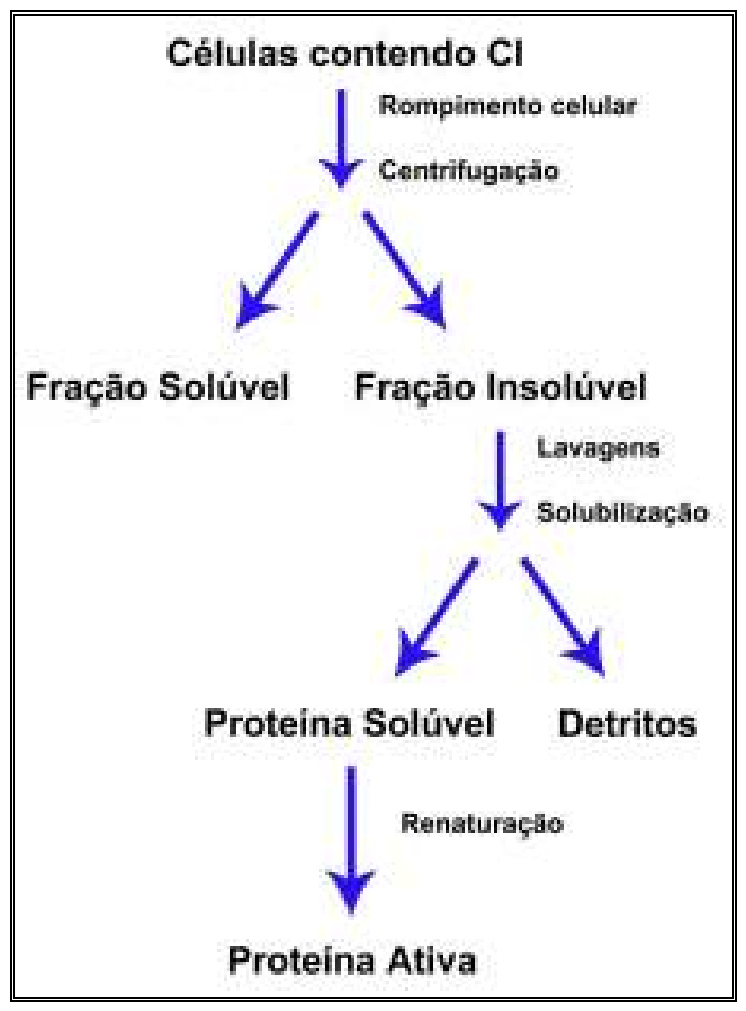

Figura 2. Etapas para a recuperação de proteínas solúveis a partir de $\mathrm{Cl}$. Modificado de Clark 2001.

\subsection{Processos Clássicos de Renaturação}

O processo de renaturação de proteínas a partir de $\mathrm{Cl}$ requer a solubilização das proteínas e sua posterior renaturação para a obtenção de conformação e atividade biológica nativas. Os processos clássicos de renaturação de proteínas a partir de agregados em $\mathrm{Cl}$ requerem $\mathrm{o}$ uso de agentes desnaturantes químicos fortes em altas concentrações. Comumente, agregados de proteínas são solubilizados em agentes caotrópicos fortes como, por exemplo, $6 \mathrm{M}$ de hidrocloreto de guanidina ( $\mathrm{Gdn} \mathrm{HCl}$ ) ou 8 M de uréia (Clark 2001; St John, Carpenter et al. 2002). Estes agentes solubilizam as proteínas nos $\mathrm{Cl}$ promovendo sua desnaturação através de uma combinação de ações. A estrutura da água é perturbada e desta forma as moléculas hidrofóbicas se tornam mais solúveis neste solvente. Os agentes desnaturantes ligam-se aos grupos polares das proteínas, rompendo as interações eletrostáticas e pontes de hidrogênio que 
mantém a estrutura proteica, resultando na desnaturação das moléculas de proteína (Caballero-Herrera, Nordstrand et al. 2005).

Uma vez solúveis e desnaturadas, as proteínas são primeiramente diluídas e então enoveladas pela remoção do agente caotrópico por diálise, diluição adicional ou métodos de fase sólida. Contudo, estes métodos convencionais de renaturação, frequentemente geram novos agregados de proteínas durante o processo de remoção do agente caotrópico, o que resulta na necessidade de utilização de concentrações protéicas muito baixas (10 a $50 \mu \mathrm{g} / \mathrm{mL}$ ) a fim de evitar a reagregação (Clark 2001). Com a finalidade de minimizar a reagregação proteica durante a renaturação, certos aditivos químicos podem ser utilizados. Os surfactantes ligam-se nas regiões hidrofóbicas expostas, protegendo a proteína da agregação, enquanto alguns açúcares e sais auxiliam na estabilização dos estados de conformação intermediária (Cowan, Davies et al. 2008).

Nos casos de proteínas que possuem pontes dissulfeto o processo de renaturação em geral é realizado na presença de agentes redutores que auxiliam na quebra de pontes dissulfeto não nativas e solubilização dos agregados e de agentes oxidantes que auxiliam na formação de pontes dissulfeto nativas. A oxidação da proteína pode ser realizada através da adição de uma mistura em proporções e concentração adequados de reagentes oxidantes e redutores, como as glutationas, cisteínas e cistaminas. A renaturação utilizando glutationas envolve a quebra das pontes não nativas e formação de pontes dissulfeto entre a glutationa e a proteína, seguida de renaturação na presença de uma quantidade de glutationa reduzida. A utilização destes reagentes aumenta a solubilidade da proteína durante a renaturação, desfavorecendo a formação de pontes dissulfeto não nativas (Clark 2001; Singh and Panda 2005).

Portanto, o passo de renaturação nos métodos clássicos é difícil e depende fortemente das condições de renaturação. Por exemplo, condições de redox, pH, taxas de diálise e concentração proteica devem ser empiricamente otimizados para cada proteína. Encontrar as condições que levem a rendimentos aceitáveis de renaturação, quando possível, geralmente requer a seleção de um grande número de condições de renaturação (Clark 1998; Vincentelli, Canaan et al. 2004). Frequentemente, após pesquisa extensiva, os rendimentos de renaturação continuam muito baixos. Além disso, baixas concentrações de proteína necessárias para rendimentos de renaturação aceitáveis, levam a grandes 
volumes de processamento e requerem grandes quantidades de agentes caotrópicos corrosivos e tóxicos (Fischer, Sumner et al. 1993).

A pressão é um parâmetro físico que modula as interações proteínasolvente através da mudança de volume do sistema (Silva and Weber 1993; Kim, Randolph et al. 2006). Os efeitos da pressão na interação entre segmentos de subunidades de uma proteína ou entre ligações intramoleculares são ditados por reações similares, que produzem essencialmente o desvio do equilíbrio em favor dos reagentes que ocupam o menor volume (princípio de Le Chatelier). A perturbação na estrutura terciária de proteínas mediada por alta pressão, ocorre devido às mudanças de volume associadas com a alteração de acessibilidade do solvente nos diferentes estados conformacionais de uma proteína, ou seja, quando em soluções aquosas e em altas pressões, as proteínas são infiltradas por água. As conformações parcialmente enoveladas de proteínas sob ação de alta pressão ligam uma quantidade substancial de água (Silva and Weber 1993). Por esta razão a desnaturação por altas pressões não ocorre na ausência de água (Mozhaev, Heremans et al. 1996).

Os volumes específicos nas proteínas agregadas e em proteínas com estrutura quaternária são maiores do que nos estados nativos devido à presença de cavidades intermoleculares não expostas à água. Em soluções aquosas de proteínas sob altas pressões hidrostáticas, o decréscimo no volume específico de proteínas quando do desenovelamento parcial ou total é causado por uma combinação de vários efeitos: 1) rompimento de pontes salinas, seguido por hidratação e decréscimo de volume correspondente devido à eletroestrição; 2) hidratação de resíduos polares e não polares recém-expostos; 3) perda de volume livre que aparece de defeitos no empacotamento de cavidades livres de água. A magnitude da diminuição do volume é pequena, 0,5 a $1 \%$ do volume total específico da proteína e as mudanças de volume para a população de estados intermediários tendem a ser ainda menores. Desta forma, a aplicação de alta pressão favorece estados proteicos contendo cavidades mínimas, estados com maior exposição de grupos hidrofóbicos e estados mais altamente ionizados (Silva and Weber 1993; Mozhaev, Heremans et al. 1996; Randolph, Seefeldt et al. 2002; Seefeldt, Ouyang et al. 2004). O esquema mostrado na figura 3 demonstra o fenômeno de dissociação de uma proteína dimérica promovida pela alta pressão (Boonyaratanakornkit, Park et al. 2002). 
A alta pressão hidrostática também tem sido utilizada como uma ferramenta importante para o estudo do enovelamento de proteínas e da dinâmica e estrutura de estados intermediários do caminho de enovelamento, pois possibilita sua estabilização, tornando possível a caracterização da estrutura e dinâmica destes estados. O estudo da ação de altas pressões sobre as proteínas tem possibilitado o melhor entendimento de como os polipeptídeos se enovelam em conformações altamente estruturadas (Silva, Foguel et al. 2001). 


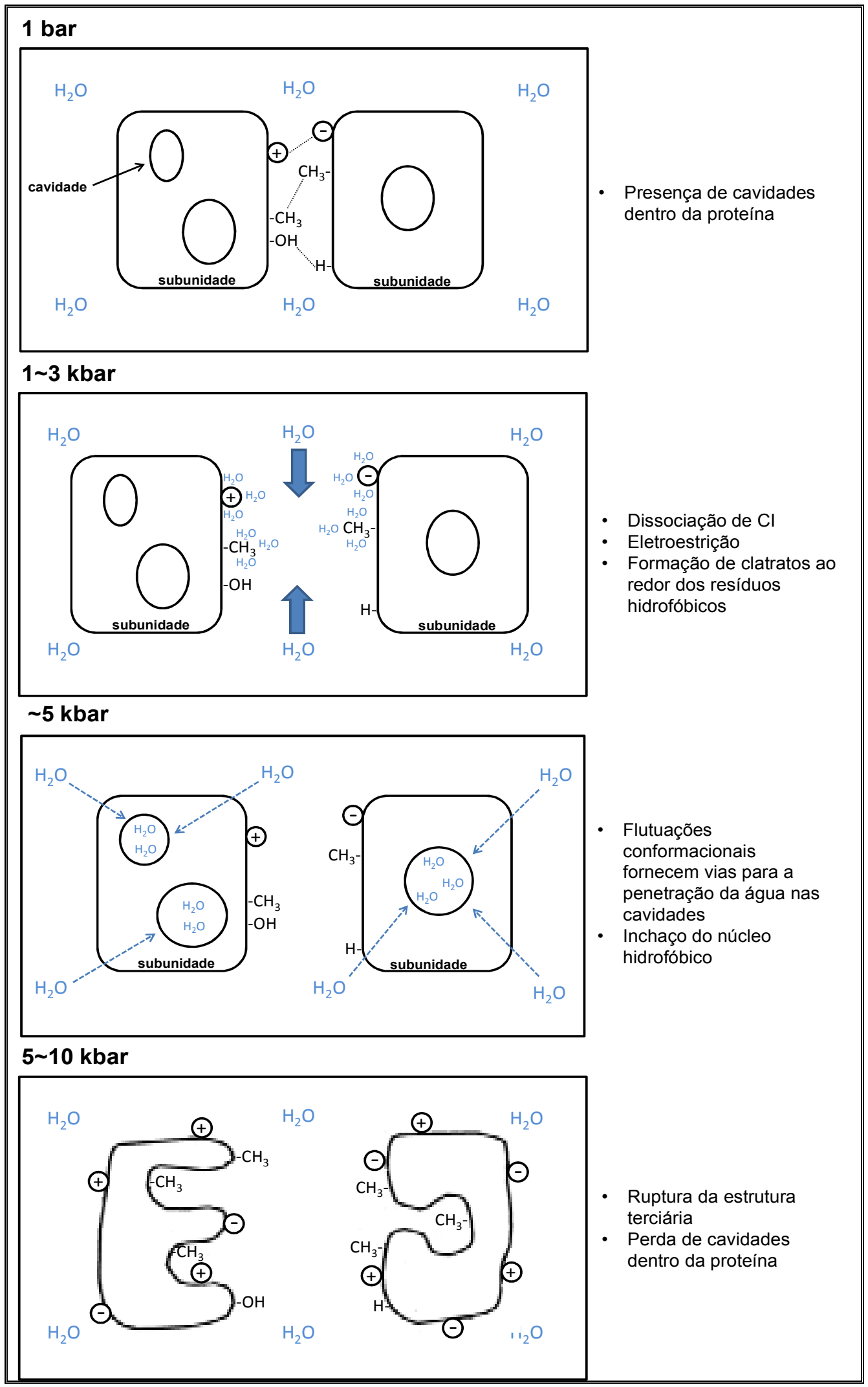

Figura 3. Efeitos da alta pressão hidrostática ocasionando a dissociação de proteínas oligoméricas e a desnaturação das subunidades. Modificado de Boonyaratanakornkit, Park et al. 2002. 
Estudos têm demostrado que altas pressões hidrostáticas são uma alternativa atrativa às técnicas tradicionais de desnaturação e diluição para a renaturação de proteínas em termos de concentração proteica, simplicidade no processo, custo e potencial para aumentar rendimentos de proteínas com conformação nativa e atividade biológica a partir de agregados (Seefeldt, Ouyang et al. 2004).

Altas pressões hidrostáticas foram descritas como capazes de solubilizar os agregados e possibilitar a renaturação de proteínas (Foguel, Robinson et al. 1999; St John, Carpenter et al. 1999; Randolph, Seefeldt et al. 2002). Como exemplo citamos os estudos que utilizaram agregados do hormônio de crescimento recombinante, da lisozima e da $\beta$-lactamase, nos quais o processo de renaturação em alta pressão hidrostática levou a altos rendimentos (> 90\%) de proteínas nativas, mesmo na presença de altas concentrações proteicas (St John, Carpenter et al. 1999; St John, Carpenter et al. 2001; St John, Carpenter et al. 2002).

Sob altas pressões ocorre a entrada de água nas estruturas proteicas. Pressões da ordem de 1 a 3 kbar desfavorecem interações intermoleculares hidrofóbicas e eletrostáticas, levando à dissociação de agregados. Os mesmos tipos de interação são também responsáveis pelas estruturas proteicas nos estados nativos. No entanto, normalmente as proteínas não são desnaturadas até pressões de 5 kbar em temperatura ambiente. Então, a dissociação de complexos macromoleculares pela aplicação de pressão de até 2 a 3 kbar não é acompanhada de perda de estruturas secundárias e terciárias existentes nos estados dissociados (Silva and Weber 1993; Silva, Foguel et al. 2001). Em contraste, as pontes de hidrogênio não são sensíveis à alta pressão hidrostática devido à desprezível mudança de volume associada à quebra dessas pontes (Randolph, Seefeldt et al. 2002). Alterações de temperatura e/ou baixas concentrações (não desnaturantes) de agentes desnaturantes como $\mathrm{Gdn} \mathrm{HCl}$ e uréia, foram descritas como úteis para facilitar a quebra das pontes de hidrogênio entre proteínas nos agregados promovida pela alta pressão (St John, Carpenter et al. 2002).

A alta pressão também não quebra pontes dissulfeto que fazem ligações cruzadas covalentes entre agregados de proteínas. Nos casos de polipeptídeos contendo pontes dissulfeto, um par óxido-redutor pode ser incluído nas soluções 
durante a compressão de modo a facilitar a quebra das pontes dissulfeto intermoleculares e formação de pontes dissulfeto nativas (St John, Carpenter et al. 2002; Chura-Chambi, Genova et al. 2008). Após a desagregação induzida por pressão, a quebra de ligações não nativas e formação de pontes dissulfeto nativas são necessárias para permitir a formação de moléculas nativas, as quais apresentam as menores energias livres (St John, Carpenter et al. 2002).

Estas propriedades claramente diferenciam a alta pressão hidrostática dos métodos tradicionais que utilizam altas concentrações de agentes caotrópicos. As principais vantagens associadas à utilização da alta pressão para dissociação de $\mathrm{Cl}$ e renaturação de proteínas recombinantes são: a solubilização das proteínas agregadas e sua renaturação ocorrem nas mesmas condições de tampão, o uso de altas concentrações de agentes caotrópicos não é necessário, o que pode possibilitar a manutenção da estrutura secundária e terciária semelhantes à nativa existentes, e a desagregação dos $\mathrm{Cl}$ ocorre rapidamente. Deste modo, a alta pressão é uma ferramenta útil para dissociação de agregados protéicos em proteínas nativas e sua renaturação, facilitando a preparação de proteínas para estudos estruturais e funcionais e também para aplicações em indústria biotecnológica (Kim, Randolph et al. 2006).

\subsubsection{Renaturação de proteínas agregadas em $\mathrm{Cl}$ utilizando altas pressões hidrostáticas}

Os primeiros dois artigos sobre a renaturação de proteínas utilizando altas pressões foram publicados no mesmo ano, 1999 (Foguel, Robinson et al. 1999; St John, Carpenter et al. 1999). Alguns artigos foram publicados após essa data descrevendo a otimização do processo de renaturação para diferentes proteínas utilizando altas pressões. A literatura ainda é pouco representativa, porém os trabalhos publicados mostram sua eficiência, sugerindo que o processo pode ter alta aplicabilidade. Algumas publicações já descreveram o desenvolvimento de processo de renaturação de proteínas a partir de $\mathrm{Cl}$ : a enzima flavina redutase (Okai, Ohtsuka et al. 2012), o fator de crescimento vascular endotelial humano (VEGF) (Cothran, St John et al. 2011), o hormônio de crescimento murino 
(Fradkin, Boand et al. 2010), as proteínas de Drosophila melanogaster "Gramnegative bacteria binding proteins" (GNBP 1, GNBP 2 e GNBP 3), duas fosfatases humanas (PTPRS e DUSP7) (Lee, Carpenter et al. 2006), membros da família de receptores nucleares (Schoner, Bramlett et al. 2005) e a $\beta$-lactamase (St John, Carpenter et al. 1999). O mais recente trabalho descreve a renaturação da proteína quimiotaxina leucocitária 2 (LECT2), com a obtenção de um alto rendimento de renaturação (10 mg/L) (Okai, Ohtsuka et al. 2012; Zheng, Miyakawa et al. 2013). Dentre estas publicações estão algumas do nosso grupo em que foram obtidas a renaturação da proteína antiangiogênica endostatina (Chura-Chambi, Genova et al. 2008), da bothropstoxina 1 de Bothrops jararacussu (Balduino, Spencer et al. 2011) e da proteína OmpA de Leptospira interrogans (Fraga, Chura-Chambi et al. 2010).

No entanto, pelo que é de nosso conhecimento, não haviam sido publicados artigos com o objetivo de estudar a ação da alta pressão sobre dissociação dos $\mathrm{Cl}$ ou sobre as estruturas proteicas com a finalidade de aprimorar este processo utilizando como modelo uma proteína fluorescente.

No presente trabalho foram utilizadas quatro proteínas: uma monomérica (GFP de Aequorea Victoria) e três oligoméricas (PilB e produtos dos genes XAC2810 e XAC3272 de Xanthomonas axonopodis pv citri - Xac) para os estudos de renaturação de proteínas agregadas em $\mathrm{Cl}$ utilizando altas pressões hidrostáticas.

\subsection{Proteína Verde Fluorescente}

\subsubsection{Bioluminescência}

A bioluminescência é um fenômeno natural observado em diversas espécies de organismos marinhos e terrestres (tabela 1). No ambiente terrestre o vagalume é o representante mais conhecido. Os animais marinhos utilizam-se da bioluminescência para afastar predadores, para camuflagem mimetizando outras espécies, para atrair suas presas e seus parceiros no período reprodutivo e como fonte alternativa de energia (Barnes 1991). O mecanismo químico de produção de 
luz por organismos marinhos difere para cada espécie. A maioria apresenta somente quimioluminescência ou bioluminescência resultante de reação química mediada por fotoproteínas. O exemplo mais bem elucidado é a reação de oxidação da luciferina a oxiluciferina catalisada pela enzima luciferase, produzindo luz. Outros mecanismos de luminescência são independentes de substrato e apresentam sistemas próprios. A fluorescência ocorre quando um elétron excitado é deslocado para uma órbita de maior energia e ao retornar para o estado de menor energia, emite um "fóton".

Tabela 1. Exemplos de organismos bioluminescentes. Retirado de Chalfie 1998.

\begin{tabular}{|c|c|c|c|}
\hline $\begin{array}{c}\text { Tipo de } \\
\text { organismo }\end{array}$ & $\begin{array}{l}\text { Gênero } \\
\text { representativo }\end{array}$ & $\begin{array}{l}\text { Mecanismos / Componentes } \\
\text { de emissão de fluorescência }\end{array}$ & $\begin{array}{l}\text { Característica / } \\
\text { Função }\end{array}$ \\
\hline Bactéria & Photobacterium & $\begin{array}{l}\text { Flavina reduzida e aldeído da } \\
\text { cadeia longa de luciferase }\end{array}$ & Emissão constante \\
\hline Dinoflagelados & Noctiluca & $\begin{array}{c}\text { Cintilação através de } \\
\text { organelas celulares }(\lambda=470 \mathrm{~nm})\end{array}$ & $\begin{array}{c}\text { Brilho em flashes } \\
\text { rápidos para afugentar } \\
\text { predadores }\end{array}$ \\
\hline $\begin{array}{l}\text { Cnidários } \\
\text { Medusas } \\
\text { Hidróides }\end{array}$ & Aequorea victoria & $\begin{array}{c}\mathrm{Ca}^{2+}, \text { coelenterazina / } \\
\text { aequorina núcleos } \\
\text { imidazólicos-pirazínicos } \\
(\lambda=470-509 \mathrm{~nm}), \text { emissão: } \\
\text { GFP }\end{array}$ & $\begin{array}{c}\text { Brilho em flashes } \\
\text { rápidos para afugentar } \\
\text { predadores. }\end{array}$ \\
\hline Ctenóforos & Beroe & $\begin{array}{c}\mathrm{Ca}^{2+}, \text { coelenterazina } \\
(\lambda=460 \mathrm{~nm})\end{array}$ & $\begin{array}{c}\text { Brilho em flashes } \\
\text { rápidos para afugentar } \\
\text { predadores }\end{array}$ \\
\hline Crustáceos & Cypridina & $\begin{array}{l}\text { núcleos imidazolícos- } \\
\text { irazínicos }(\lambda=465 \mathrm{~nm})\end{array}$ & $\begin{array}{c}\text { Liberar enzimas em } \\
\text { substratos }\end{array}$ \\
\hline $\begin{array}{l}\text { Insetos, vaga- } \\
\text { lume }\end{array}$ & Photinus, Photuris & $\begin{array}{c}\text { núcleo benzotiazólico, ATP, } \\
\mathrm{Mg}^{2+}(\lambda=550-580 \mathrm{~nm})\end{array}$ & $\begin{array}{c}\text { Flashes, afastar } \\
\text { predadores, } \\
\text { acasalamento }\end{array}$ \\
\hline
\end{tabular}

\subsubsection{Aequorea victoria}

A Aequorea victoria é um cnidário de corpo totalmente transparente em forma de guarda-chuva, com diâmetro entre 7 e $10 \mathrm{~cm}$ que apresenta grânulos bioluminescentes ao redor de seu corpo, formando um círculo (figura 4). 


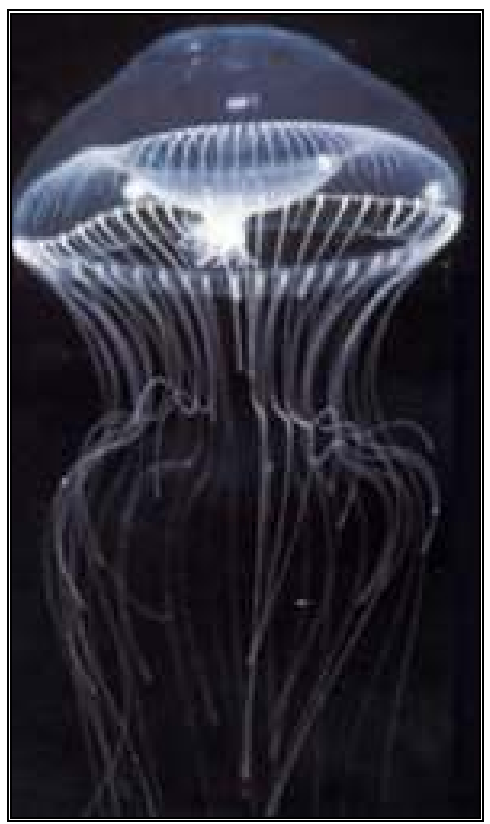

Figura 4. Aequoria Victoria. Restirado de http://cienciaemdia.folha.blog.uol.com.br/arch2008-1005_2008-10-11.html.

A produção da luminescência ocorre por meio de uma reação química altamente exotérmica em que a oxidação de uma molécula orgânica, genericamente chamada de luciferina, libera energia preferencialmente na forma de luz visível. Essa reação é catalisada por enzimas chamadas de luciferases. A natureza química das luciferinas, cofatores e a seqüência e estrutura destas proteínas variam de um grupo taxonômico a outro, levando a conclusão que a bioluminescência se originou várias vezes e independentemente durante a evolução (de Farias 2009).

No caso das águas-vivas do gênero Aequorea, a bioluminescência é em geral verde. Curiosamente, os primeiros estudos bioquímicos, que tentavam caracterizar o sistema bioluminescente dessas águas-vivas, mostraram que a ruptura da estrutura celular dos grânulos presentes nas medusas resultava no isolamento de uma luciferase e luciferina que produziam luz azul, em vez de verde, como observado no animal vivo. Havia um terceiro componente que produzia luminescência verde (Shimomura, Johnson et al. 1962). Foi essa observação que levou Osamu Shimomura a isolar a proteína verde fluorescente em 1962 e como consequência deste importante achado, receber o prêmio Nobel de Química em 2008. Essa proteína, embora não seja luminescente por si só, ao 
ser irradiada com luz visível na faixa azul do espectro, produz uma luminescência verde intensa, devido à fluorescência. O grupo de Shimomura verificou que, no sistema bioluminescente intacto das medusas, quem transfere a energia para a GFP é a própria reação bioluminescente da luciferase e luciferina. Quando o complexo luciferase-luciferina e a GFP estão suficientemente próximos, a energia de excitação do complexo luciferase-oxiluciferina é eficientemente transferida para a GFP, que fluoresce na região do verde. Essa modalidade de transferência de energia é chamada de transferência por ressonância e depende da proximidade e sobreposição dos espectros de emissão do doador de energia (o complexo luciferase-oxiluciferina excitada) e de absorção do aceptor de energia (a GFP) (Shimomura, Johnson et al. 1962; de Farias 2009).

\subsubsection{Proteína verde fluorescente selvagem (GFP) e "Enhanced" GFP (eGFP)}

O mesmo grupo de Shimomura publicou o espectro de emissão da GFP, com o pico de excitação em 395 - 397 nm e de emissão em 504 nm (Tsien 1998). A GFP é uma proteína monomérica com 238 resíduos, cadeia única de polipeptídeos com massa molecular de $27 \mathrm{kDa}$. A proteína GFP consiste de 11 folhas $\beta$ em forma de barril com uma $\alpha$-hélice contendo o fluoróforo ao centro (figura 5) (Ormo, Cubitt et al. 1996).

O cromóforo é uma p-hidroxibenzilideno imidazolinona formada pelos resíduos 65 - 67 (Ser-Tyr-Gly) na proteína nativa. Para a formação do cromóforo, a GFP se enovela numa conformação quase nativa e então a imidazolinona é formada pelo ataque nucleofílico da amida da Gly67 na carbonila do resíduo Ser $_{65}$, seguido de oxidação (figura 6). Finalmente, ocorre a etapa de desidratação que envolve a perda de um dos hidrogênios do $\mathrm{C}_{\beta}$ do resíduo $\mathrm{Tyr}_{66}$. Somente neste estágio que o cromóforo adquire absorbância e fluorescência visível (Heim, Prasher et al. 1994; Cubitt, Heim et al. 1995; Reid and Flynn 1997). A formação do cromóforo na forma madura da GFP é autocatalítica e oxigênio é fundamental para o desenvolvimento da fluorescência. 


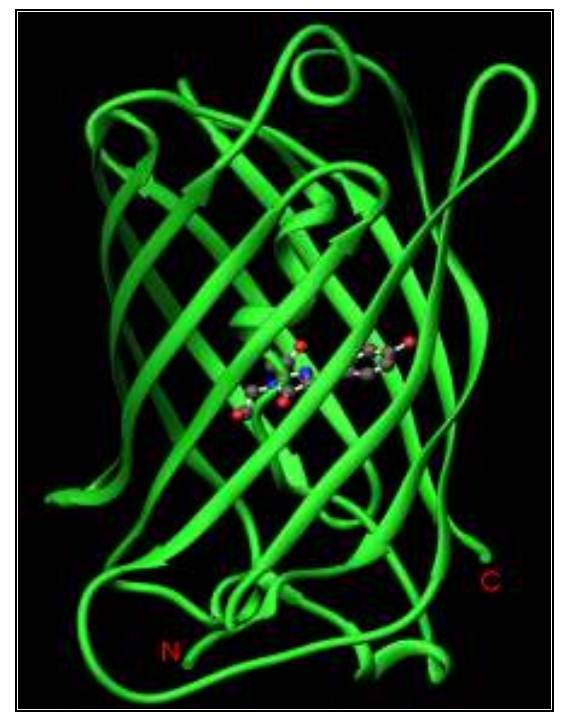

Figura 5. Estrutura tridimensional da GFP. A estrutura em barril $\beta$ se enovela com o cromóforo ao centro, mostrado como esferas. Átomos de carbono são mostrados em cinza, nitrogênio em azul e oxigênio em vermelho. Retirado de de Farias 2009.

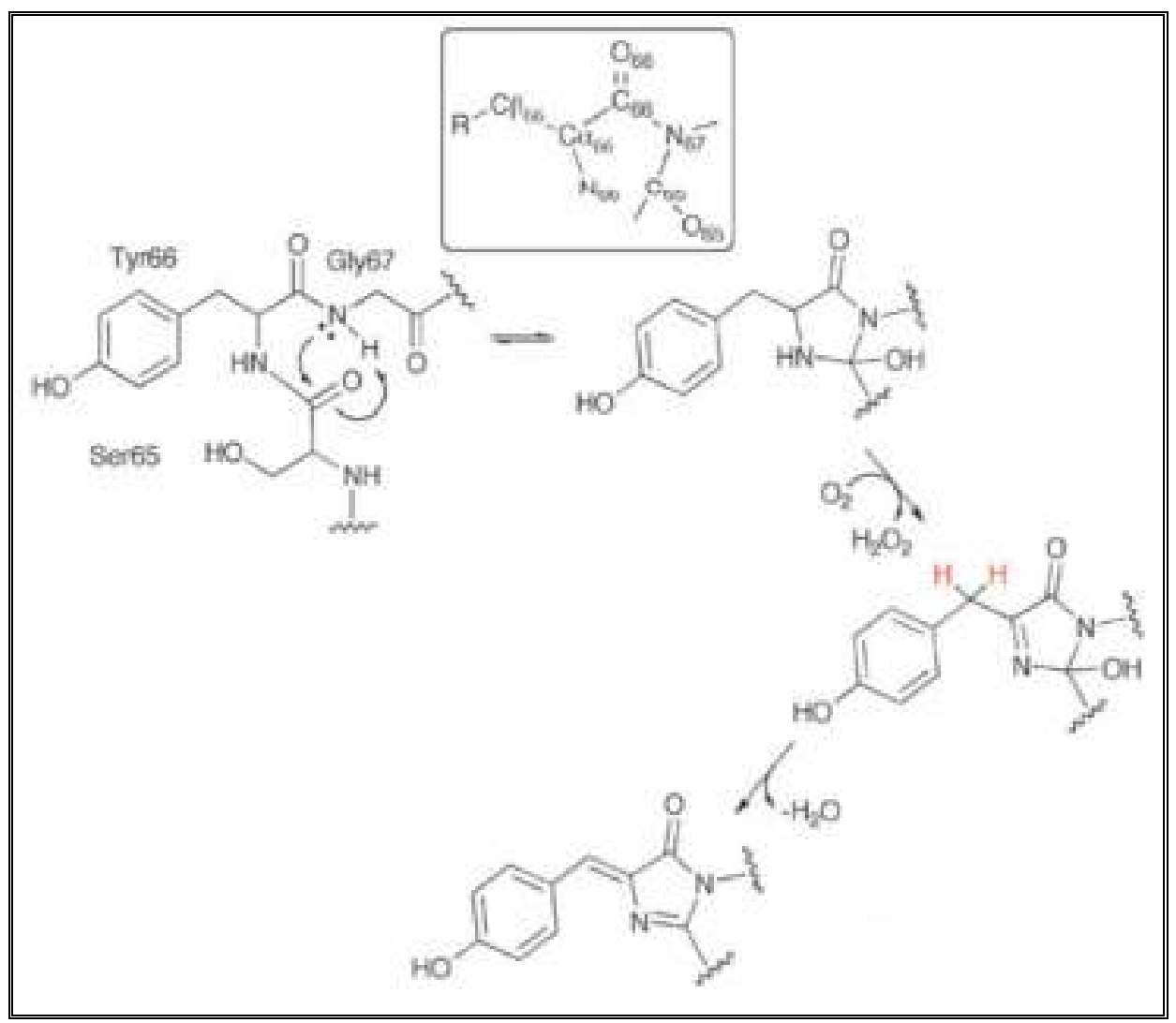

Figura 6. Mecanismo para a maturação do cromóforo. Após o enovelamento da GFP, ocorre a ciclização que é formada pelo ataque nucleofílico do nitrogênio da amida da Gly 67 no carbono da carbonila da $\operatorname{Ser}_{65}$, formando o anel imidazolona. A molécula intermediária é oxidada e subsequentemente ocorre a desidratação gerando o cromóforo maduro. Modificado de Craggs 2009. 
A GFP se mostra estável mesmo em altas temperaturas. Esta estabilidade parece ser conseqüência da sua estrutura tridimensional única. As onze folhas $\beta$ rodeiam e protegem o cromóforo que é posicionado perto do centro geométrico da estrutura em barril. Regiões de pequenas dobras e a-hélices distorcidas tampam ambas as extremidades do barril. A proteção é tão completa que agentes clássicos que extinguem a fluorescência não possuem quase efeito sobre a fluorescência da GFP (Yang, Moss et al. 1996).

A desnaturação da GFP por ácidos, bases ou $\mathrm{Gdn} \mathrm{HCl}$ resulta em perda de fluorescência, no entanto, a GFP desnaturada recupera a fluorescência após o retorno a um pH neutro ou diluição da $\mathrm{Gdn} \mathrm{HCl} \mathrm{(Bokman} \mathrm{and} \mathrm{Ward} \mathrm{1981;} \mathrm{Ward}$ and Bokman 1982).

O comportamento de uma forma mutante de GFP (red-shifted GFP, rsGFP) sob altíssimas pressões foi descrito, tendo sido demonstrado que este mutante sofre alteração de estrutura em pressões da ordem de 4 kbar, pressão na qual ocorrem pequenas mudanças na região do cromóforo, que são acompanhadas pela penetração de água na estrutura de $\beta$-barril, com decréscimo de emissão de fluorescência. A desnaturação da rsGFP ocorre por colapso da estrutura de $\beta$ barril em pressões bem mais altas, da ordem de 9 kbar (Herberhold, Marchal et al. 2003). A GFP selvagem e alguns mutantes (entre eles a enhanced GFP, eGFP) se mostraram mais estáveis do que a rsGFP sob altas pressões hidrostáticas. Sob pressões de até $600 \mathrm{MPa}$ (6 kbar) não houve decréscimo de fluorescência dos mutantes testados, com exceção da rsGFP (Ehrmann, Scheyhing et al. 2001). Foi demonstrado que as estruturas secundárias da GFP e também da eGFP, monitoradas por meio de estudos de espectroscopia de infravermelho (FT-IR), são mantidas em pressões de até 13 - 14 kbar (Scheyhing, Meersman et al. 2002), confirmando que as GFPs são altamente resistentes à desnaturação pela aplicação de pressão.

A necessidade da estrutura nativa da proteína para a emissão de fluorescência foi demonstrada pelas informações que foram obtidas com a estrutura cristalográfica das GFPs (Ormo, Cubitt et al. 1996; Yang, Moss et al. 1996), na qual se demonstrou que o fluoróforo interage com vários resíduos distantes na sequência primária. Conseqüentemente a GFP possui uma grande vantagem para o estudo de enovelamento de proteína, que é a facilidade de monitoramento do enovelamento em tempo real, sob altas pressões e utilizando a 
fluorescência como marcador de recuperação da estrutura nativa. De fato, a renaturação da GFP já foi bem descrita (Weissman, Rye et al. 1996; Makino, Amada et al. 1997; Fukuda, Arai et al. 2000; Wielgus-Kutrowska, Narczyk et al. 2007), mas a sua renaturação utilizando altas pressões ainda não. O fato de que a estrutura nativa deve estar presente para a emissão de sua fluorescência característica (Ormo, Cubitt et al. 1996) e a simplicidade de monitoramento da bioatividade da GFP tornam esta proteína um excelente sistema modelo para estudos de renaturação sob pressão. Nós consideramos que o estudo das condições de desagregação e renaturação de eGFP agregada em $\mathrm{Cl}$ sob altas pressões seria muito útil como modelo de renaturação de outras proteínas nessas condições.

No presente estudo utilizamos a enhanced GFP (eGFP), um mutante com as mutações F64L e S65T, que apresenta fluorescência mais elevada do que a forma selvagem, excitação em 488 nm e pico de fluorescência entre 507 - 509 nm (Tsien 1998).

\subsection{Proteínas de Xanthomonas axonopodis pv citri}

\subsubsection{Papel do cancro cítrico na economia brasileira}

$\mathrm{Na}$ década de 80 o Brasil se tornou o maior produtor mundial de laranja, sendo destinada a produção de suco concentrado (Hasse 1987; Bevan 2000). O Brasil tem mais de 1 milhão de hectares de terra com cutlivo de plantas cítricas e produz, aproximadamente, um terço dos frutos cítricos mundiais, respondendo por $80 \%$ de suco de laranja concentrado negociado mundialmente, os quais absorveram mais de US\$1,2 bilhão para o Brasil, fato este, explica a relevância da cadeia agroindustrial citrícola na economia brasileira, no agronegócio e na balança comercial do país (Hasse 1987; Bevan 2000).

O Estado de São Paulo é o principal polo produtor brasileiro, correspondendo a $87,7 \%$ da produção anual nacional e $30 \%$ da mundial. $O$ volume de recursos movimentados pelo agronegócio citrícola supera $\mathrm{R} \$ 5$ bilhões por ano, gerando cerca de 400 mil empregos diretos com 3 mil frentes de trabalho 
na colheita e cerca de 3 milhões de empregos indiretos, somente no Estado de São Paulo (Pruvost, Boher et al. 2002; Moreira, Almeida et al. 2010).

Apesar do grande potencial da citricultura Brasileira, o país vem perdendo um espaço significatico no comércio internacional, devido a problemas fitossanitários. A citricultura brasileira é alvo de uma grande variedade de doenças, entre elas o cancro cítrico, causando grandes prejuízos às lavouras de citros no país, pondo em risco benefícios econômicos e sociais gerados pela agricultura. O cancro cítrico foi constatado pela primeira vez no Brasil em 1957, encontrado inicialmente em pomares na região de Presidente Prudente em São Paulo, trazida em mudas importadas por imigrantes japoneses. A doença foi posteriormente detectada em regiões dos Estados de São Paulo, Mato Grosso do Sul, Paraná, Santa Catarina e Rio Grande do Sul (Bitancourt 1957; Namekata 1996). A doença se alastrou rapidamente pela região produtora e, atualmente, é citada como um dos principais fatores responsáveis pela retração na produtividade de citros do país e também sendo a causadora de prejuízos da ordem de centenas de milhões de Reais por ano em nosso país.

Segundo Leite (1990) e Rossetti (2001) são conhecidos cinco tipos de cancro cítrico, os quais podem ser distinguidos de acordo com a diferença em patogenicidade e sintomas apresentados, em função de espécies de Citrus e outros gêneros afins infectados. Os genes das proteínas utilizados no presente trabalho foram isolados da bactéria Xac (Leite JR 1990; Rossetti 2001).

Xanthomonas é um gênero de fitopatógeno bacteriano responsável por doenças em algumas variedades de hospedeiros, incluindo citros, arroz, uva, feijão e algodão (Swings 1993). O grande problema do cancro cítrico é a sua difícil erradicação e a sua fácil e rápida disseminação, podendo ocorrer através do vento, da chuva e do próprio homem. A Xac, invade seu hospedeiro (Citrus spp) através dos estômatos e lenticelas (Gottwald 2009). Desse modo, todos os tecidos aéreos como ramos, folhas e frutos são susceptíveis ao ataque (figura 7) (Schubert 2003). Os primeiros sintomas do cancro cítrico se manifestam nas folhas, como lesões necróticas arredondadas, salientes e de coloração amarronzada ao centro e amarelada ao redor, nos dois lados das folhas. Posteriormente estas lesões aparecem nas frutas e nos ramos diminuindo a quantidade e a qualidade das frutas e, portanto inviabilizando comercialmente a planta (http://www.fundecitrus.com.br; Brunings and Gabriel 2003; Gottwald 2009). 


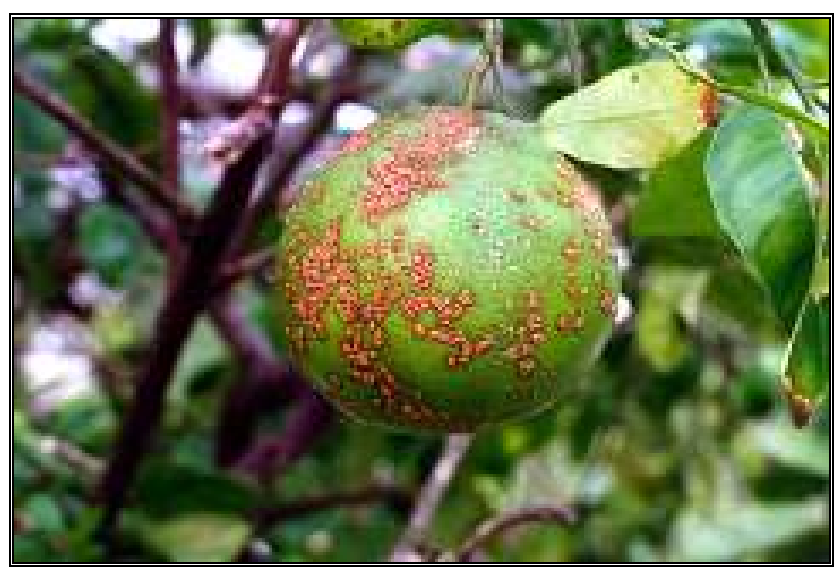

Figura 7. Citros mostrando sintomas de Cancro cítrico. Folhas e frutos infectados em estado avançado da doença. Retirado de http://www.caripestnetwork.org.

Embora o cancro cítrico seja responsável por grandes perdas econômicas na produção das frutas cítricas, não foi descoberta nenhuma forma eficaz para sua erradicação e o procedimento adotado para evitar uma possível epidemia em toda lavoura é a detecção precoce da doença e a erradicação de plantas contaminadas a um raio de 30 metros do foco de contaminação (figura 8) (Timmer 2006; Lowe 2009).

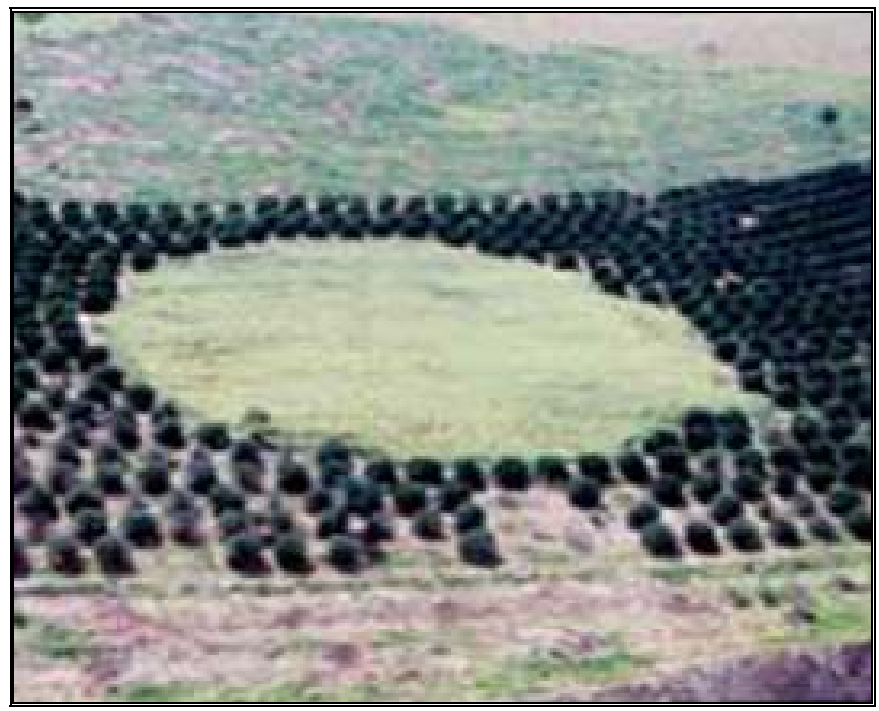

Figura 8. Vista aérea da erradicação de árvores de laranja em um raio de 30 metros em relação ao centro do foco da contaminação por Xac. Retirado de http://www.redetec.org.br/inventabrasil/xanto.htm. 


\subsubsection{Xanthomonas axonopodis pv citri}

A agricultura brasileira e mundial é bastante afetada por várias doenças ocasionadas por espécies do gênero Xanthomonas, provocando assim, perdas substanciais em várias culturas de grande importância econômica. Esse gênero contém uma ampla variedade de espécies, linhagens, e hospedeiros (124 monocotiledôneas e 286 dicotiledôneas) (Leyns 1984) e representa o maior grupo de bactérias fitopatogênicas, o qual apresenta uma extraordinária diversidade patogênica e importância econômica (http://www.fundecitrus.com.br; Chan and Goodwin 1999; Vauterin 2000; Vicente 2001; Brunings and Gabriel 2003; Buttner and Bonas 2009; Gottwald 2009). Além disso, a Xac, agente etiológico do cancro cítrico, está entre as Xanthomonas que causam maior impacto na agricultura mundial (Schubert 2003).

Bactérias do gênero Xanthomonas são cosmopolitas, com duas características morfológicas comumentes presentes: 1) produção de goma xantana (exopolissacarídeo que auxilia na dispersão e sobrevivência do patógeno, além de ser uma importante matéria prima nas indústrias de alimentos), que leva as suas colônias a possuirem um aspecto mucóide e 2) possuem cor amarela devido à produção de pigmentos, principalmente xantomonadina, quando cultivadas em meio Nutriente Ágar, após 2 ou 3 dias de incubação a $28^{\circ} \mathrm{C}$ (Bebendo 1995; Vauterin 1996). A Xac se adapta bem em temperatura de $20^{\circ} \mathrm{C}$ $30^{\circ} \mathrm{C}$, condição que adicionada ao elevado teor de umidade é excelente para o crescimento e desenvolvimento da infecção (Peltier 1920; Bebendo 1995).

\subsubsection{Genômica Funcional e Proteômica}

A proteômica, entendida como a análise em larga escala da expressão proteica, é atualmente considerada uma das áreas centrais da genômica funcional. De fato, os avanços técnicos que permitem resolver e identificar centenas ou milhares de proteínas a partir de extratos proteicos complexos, através de tecnologia proteômica envolvendo separação eletroforética ou cromatografia aliada à espectrometria de massas, possibilita a aquisição em larga 
escala de informações sobre o repertório de proteínas envolvidas diretamente com diferentes situações metabólicas e fisiológicas de um dado organismo, e ainda detectar modificações pós-traducionais (Anderson 1997). Além disso, o grande número de sequências disponibilizadas pelos projetos de sequenciamento de genomas tem favorecido o interesse em análises de proteomas, visto que, através de informações do sequenciamento de um organismo pode-se deduzir proteínas codificadas num genoma, o que é de fundamental auxílio no processo de identificação das proteínas detectadas pela análise proteômica, bem como da regulação da expressão destas (Jungblut 1995). Utilizar a alta pressão como ferramenta para a obtenção de proteínas solúveis e biologicamente ativas a partir de $\mathrm{Cl}$ é particularmente interessante para possibilitar a continuidade de projetos como o do genoma da Xac, ao qual se seguiu o projeto de genoma estrutural. Isto se deve ao fato de que a estrutura e atividade biológica de muitas das proteínas que foram expressas como $\mathrm{Cl}$ em $E$. coli não foram estudadas devido às dificuldades encontradas para sua renaturação. A produção de proteínas envolvidas com a motilidade e virulência bacterianas apresentando a conformação nativa e biologicamente ativas pode ser um passo inicial para a compreensão dos processos relacionados à patogenicidade de bactérias economicamente importantes como a Xac.

O sequenciamento completo e anotação do genoma da bactéria Xac ( $\mathrm{Da}$ Silva 2002), revelaram um cromossomo circular com 5.175.554 pares de bases (pb) e dois plasmídeos o pXAC64 (64.920 pb) e o pXAC33 (33.699 pb). Essa constituição genética é responsável por codificar 4.428 proteínas, sendo que, deste total $2.770(62,6 \%)$ proteínas tiveram suas respectivas funções associadas às proteínas com funções conhecidas descritas na literatura, e $1.653(37,4 \%)$ correspondem às proteínas hipotéticas sem função descrita até então (Da Silva 2002). As proteínas utilizadas no presente trabalho são: PilB codificada pelo gene XAC3239, e produtos dos genes XAC2810 e XAC3272.

A proteína PilB de Xac possui 578 aminoácidos, 62 kDa e possui alta identidade de sequência primária $(92 \%)$ com outras proteínas PilB de outros organismos. Está envolvida na biogênese do pilus tipo IV (T4P), um filamento fino encontrado na superfície de células bacterianas que está envolvido na patogenicidade bacteriana, incluindo, por exemplo, movimento involuntário, adesão em superfícies, transformação natural, formação de biofilme, secreção de 
proteínas e quimiotaxia (Mattick 2002; Craig, Pique et al. 2004; Han, Kennan et al. 2007; Craig and Li 2008). A biogênese do T4P é um processo complexo que envolve uma grande quantidade de proteínas, no qual PilB, via consumo de ATP, forma uma estrutura hexamérica na face citosólica da membrana interna bacteriana que compõem o funcionamento geral do T4P em vários processos biológicos, como por exemplo, no processo de autotransformação e no processo de adesão à superfície. As proteínas PilB possuem atividade ATPásica, porém somente havia sido determinada a atividade da proteína PilB de Myxococcus xanthus e de Pseudomonas aeruginosa. No entanto, sua estrutura ainda não foi descrita (Chiang, Sampaleanu et al. 2008; Jakovljevic, Leonardy et al. 2008).

As proteínas produtos dos genes XAC2810 e XAC3272, possuem 356 e 307 aa e massa molecular de 42,2 e $34,5 \mathrm{kDa}$, respectivamente. Pelo fato de possuírem alta identidade de sequência primária com outras proteínas de outros organismos, possuindo em suas sequências os domínios GAF e GGDEF conservados, é forte a possibilidade de que sejam enzimas diguanilato ciclases, envolvidas na síntese do segundo mensageiro diguanilato cíclico, bis-(3', 5')-diguanosina monofosfato cíclico (c-di-GMP). A estrutura secundária e a atividade biológica das proteínas ainda não foram descritas, mas por homologia acredita-se que seus domínios GGDEF poderiam possuir atividade de diguanilatos ciclase, a qual convertem 2 moléculas de GTP e liberam fosfato inorgânico e somente sejam ativas na forma de dímeros (Drenkard and Ausubel 2002; Chiang, Sampaleanu et al. 2008; Jakovljevic, Leonardy et al. 2008).

O c-di-GMP é uma molécula de sinalização intracelular universalmente encontrada em bactérias. Trabalhos recentes em diferentes organismos mostram que altos níveis de c-di-GMP promovem o estado séssil das células, associado ao aumento da produção de componentes extracelulares de adesão como polissacarídeos e fimbrias. Inversamente, baixos níveis de c-di-GMP promovem a motilidade celular e virulência (Simm, Morr et al. 2004). As proteínas codificadas pelos genes XAC2810 e XAC3272 são constituídas por dois domínios, um domínio GAF no N-terminal e um domínio GGDEF no C-terminal. O domínio GGDEF de XAC2810 possui o motivo conservado GGEEF o que sugere ser um domínio ativo, já o domínio GGDEF do gene XAC3272 possui um motivo degenerado (AEGEF) e provavelmente não seja capaz de sintetizar c-di-GMP, mas talvez seja capaz de ligar ao c-di-GMP. 
Utilizar a alta pressão como ferramenta para a obtenção de proteínas solúveis e biologicamente ativas a partir de $\mathrm{Cl}$ é particularmente interessante para possibilitar a continuidade de projetos como o do genoma da Xac. Isto se deve ao fato de que a estrutura e atividade biológica de muitas das proteínas que foram expressas como $\mathrm{Cl}$ em $E$. coli não foram estudadas devido às dificuldades encontradas para a obtenção de proteínas solúveis ou renaturadas. A produção de proteínas envolvidas com a patogenicidade bacterianas apresentando a conformação nativa e biologicamente ativas pode ser um passo inicial para a compreensão dos processos relacionados à infecção por Xac. 


\section{OBJETIVOS}

Utilizando como modelo a proteína eGFP, estudar e otimizar o processo de solubilização dos Cls e renaturação desta proteína utilizando alta pressão hidrostática. Com base na otimização da metodologia utilizada, produzir as proteínas de Xac solúveis e com atividade biológica a partir de agregados expressos em Escherichia coli. 


\section{MATERIAIS E MÉTODOS}

\subsection{Materiais}

\subsubsection{Equipamentos e acessórios principais}

- Agitador, modelo Ts-2000 ${ }^{\mathrm{a}}$, Vertex.

- Aparelho Mili-Q Plus, purificador de água, Milipore.

- Autoclave, modelo 12 LI/LA, Kavo.

- Autoclave, modelo 415, Fanem.

- Balança analítica, modelo AW 220, Shimadzu.

- Balança de precisão, modelo P1200, Mettler.

- Banho-maria, modelo 100, Fanem.

- Banho-maria, modelo Type 16500 Dry-Bath, Thermolyne.

- Banho-maria, modelo Cool Tech 320, Thermo Scientific.

- Bomba peristáltica, modelo P1TM, GE Healthcare.

- Câmera fotográfica, modelo DMC-FX100, Lumix Panasonic.

- Centrífuga refrigeradora automática, modelo 5810R, Eppendorf.

- Centrífuga refrigeradora automática, modelo RC2-B, Sorvall Speed.

- Coluna de afinidade, modelo His Trap HP, GE Healthcare.

- Coluna de exclusão molecular, modelo Superdex 75 10/30 GL, GE Healthcare.

- Coluna de exclusão molecular, modelo Superdex 200 10/300 GL, GE Healthcare.

- Eletroporador, modelo II, Invitrogen.

- Espectrofluorímetro, modelo Cary Eclipse, Varian.

- Espectrofotômetro, modelo Genesys 6, Thermo Scientific.

- Espectrometro de infravermelho, Nicolet 6700, Thermo Corp., USA

- Estufa para cultura bacteriana, modelo Q-316B, Quimis.

- Forno de microondas, LG.

- Freezer $-20^{\circ} \mathrm{C}$, Bosch. 
- Freezer $-80^{\circ} \mathrm{C}$, modelo AL880 E, American Lab.

- Incubadora refrigerada com agitação, modelo TE421, Tecnal.

- Kit de Ensaio de Fosfato EnzChek ${ }^{\circledR}$, Molecular Probes, Invitrogen.

- Leitor de D.O., modelo Ultrospec 10, Amersham Bioscience.

- Microscópio eletrônico de varredura, modelo XL200, Phillips.

- Seladora a vácuo, modelo TM 150, TecMaq.

- Sistema de Eletroforese vertical, modelo Tetra System, Bio-Rad.

- Sonicador, modelo 3000, Biologics.

- Transiluminador, modelo Mocrouve, Hoefer.

- Vaso de alta pressão, modelo R4-6-40 e bomba, modelo P40, High Pressure Equipment.

\subsubsection{Reagentes e soluções}

- Ácido Acético Glacial, Merck.

- Ácido Clorídrico, Merck.

- Acrilamida, Reagen.

- Ágar, Difco.

- Agarose, BioAgency.

- Ampicilina, Bayer.

- Bis-acrilamida, BioAgency.

- Bis-ANS, Sigma-Aldrich.

- BSA, Sigma-Aldrich.

- Casaminoácidos, BD.

- Cloreto de cálcio, Sigma-Aldrich.

- Cloreto de sódio, Synth.

- Comassie brilliant Blue G-250, Sigma-Aldrich.

- Deoxicolato de sódio, Sigma-Aldrich.

- Ditiotreitol, Sigma-Aldrich.

- Dodecil Sulfato de Sódio, Êxodo Científica.

- Extrato de levedura, BD. 
- Glicerol, Serva.

- Glicina, Sigma-Aldrich.

- Glicose, Casa Americana.

- Glutationas reduzida e oxidada, Sigma-Aldrich.

- Hidrocloreto de Guanidina, Sigma-Aldrich.

- Imidazol, Sigma-Aldrich.

- Isopropil, $\beta$-D-tiogalactopiranosíde, Fermentas.

- Kanamicina, Invitrogen.

- L-Arginina, Sigma-Aldrich.

- Lisozima, Sigma-Aldrich.

- Membrana de diálise, Sigma-Aldrich.

- Padrão de Massa molecular, GE Healthcare.

- PEG 600, Sigma-Aldrich.

- Persulfato de amônio, BioAgency.

- Sacarose, In Lab.

- Soroalbumina bovina, Sigma-Aldrich.

- Sulfato de Magnésio, Synth.

- Sulfato de Níquel, GE Healthcare.

- Sulfato de Potássio, Synth.

- Triptona, Difco.

- Tris base, Vetec.

- Triton X-100, Sigma-Aldrich.

- Tween-20, Merck.

- Uréia, Poliscience.

- Verde Malaquita, Synth.

\subsubsection{Linhagem celular bacteriana}

A cepa de $E$. coli utilizada para a expressão das proteínas eGFP, PilB e os produtos dos genes XAC2810 e XAC3272 foi a BL-21 (DE3) pLysS: [F', ampT, $\mathrm{hsdS}_{\mathrm{b}}\left(\mathrm{r}_{\mathrm{B}}{ }^{-} \mathrm{m}_{\mathrm{B}}{ }^{-}\right)$, gal, dcm $\lambda$ (DE3)] (Novagen EMD Biosciences, Inc.). 


\subsubsection{Vetores plasmídicos}

- pAE: vetor de expressão que contém clonado o gene codificador da proteína eGFP, doado pelo Dr. Geraldo Santana Magalhães do Laboratório de Imunopatologia do Instituto Butantan. A proteína expressa é a "enhanced green fluorescent protein" (eGFP), que apresenta fluorescência aumentada em relação à cepa selvagem, devido às mutações F64L e S65T (Tsien 1998).

- pET28a: vetor de expressão que contém clonado o gene XAC3239 (codificador da proteína PilB), e o gene XAC3272, ambos doados pelo Dr. Shaker Chuck Farah do Instituto de Química da Universidade de São Paulo.

- pProExHTb: vetor de expressão que contém clonado o gene XAC2810, doado pelo Dr. Shaker Chuck Farah do Instituto de Química da Universidade de São Paulo.

\subsection{Métodos}

\subsubsection{Transformação e expressão}

As cepas BL21(DE3) de E. coli foram transformadas por eletroporação, seguindo protocolo descrito pelo fabricante do eletroporador (Invitrogen) e em seguida plaqueadas em meio ágar LB (10 g/L de triptona, $5 \mathrm{~g} / \mathrm{L}$ de extrato de levedura, $10 \mathrm{~g} / \mathrm{L}$ de $\mathrm{NaCl}$ e $15 \mathrm{~g} / \mathrm{L}$ de ágar), contendo o antibiótico adequado (Tabela 2). As culturas foram mantidas em estufa por 16 horas a $37^{\circ} \mathrm{C}$. As colônias transformantes foram escolhidas aleatoriamente e repicadas em $15 \mathrm{~mL}$ de meio rico 2HKII (10 g/L de extrato de levedura, $20 \mathrm{~g} / \mathrm{L}$ de triptona, $4 \mathrm{~g} / \mathrm{L}$ de casaminácidos, 0,8 g/L de sulfato de magnésio, $0,08 \mathrm{~g} / \mathrm{L}$ de cloreto de cálcio, 3,1

$\mathrm{g} / \mathrm{L}$ de sulfato de potássio e $320 \mu \mathrm{l} / \mathrm{L}$ de solução traço de metais) (Jensen and Carlsen 1990) na presença do antibiótico específico e mantidas em incubadora a $37^{\circ} \mathrm{C}$ com agitação de $200 \mathrm{rpm}$. Este volume foi então diluído em $250 \mathrm{~mL}$ do mesmo meio de cultura, em erlenmeyer de $1000 \mathrm{~mL}$, contendo o antibiótico 
específico e mantidas a $200 \mathrm{rpm}$ a $37^{\circ} \mathrm{C}$ até atingirem a densidade óptica (D.O. 600 $\mathrm{nm}$ ) de 3,0 . As culturas foram então induzidas à expressão pela adição de isopropil- $\beta$-D-tiogalactopiranosideo (IPTG) em concentração final de 0,5 mM e incubadas às temperaturas de $37^{\circ} \mathrm{C}, 42^{\circ} \mathrm{C}$ e $47^{\circ} \mathrm{C}$ para a proteína eGFP e $20^{\circ} \mathrm{C}$, $25^{\circ} \mathrm{C}, 30^{\circ} \mathrm{C}$ e $37^{\circ} \mathrm{C}$ para as proteínas PilB e produto do gene XAC2810 e XAC3272 e foram mantidas a 200 rpm por mais 16 horas.

Tabela 2. Antibióticos utilizados para expressão das proteínas e genes alvos.

\begin{tabular}{cc}
\hline Proteínas e Genes & Antibióticos \\
\hline eGFP & Ampicilina $(100 \mu \mathrm{g} / \mathrm{mL})$ \\
\hline PilB & Kanamicina $(30 \mu \mathrm{g} / \mathrm{mL})$ \\
\hline Gene XAC2810 & Ampicilina $(100 \mu \mathrm{g} / \mathrm{mL})$ \\
\hline Gene XAC3272 & Kanamicina $(30 \mu \mathrm{g} / \mathrm{mL})$ \\
\hline
\end{tabular}

\subsubsection{Lavagem dos $\mathrm{Cl}$}

As suspensões contendo as bactérias foram centrifugadas a $10.000 \mathrm{~g}$ por 10 minutos a $4^{\circ} \mathrm{C}$ e o sobrenadante foi descartado. Os botões celular foram ressuspendidos em tampão $A$ (Tris $\mathrm{HCl}$ 0,1 M, pH 7,5 e $5 \mathrm{mM}$ EDTA) e $50 \mu \mathrm{g} / \mathrm{mL}$ de lisozima foi adicionada às soluções. As suspensões foram então incubadas em temperatura ambiente por 15 minutos e em seguida foram sonicadas na presença de $0,1 \%$ de deoxicolato de sódio por 30 segundos com intervalos de 30 segundos a $60 \mathrm{~Hz}$ em banho de gelo. As suspensões foram novamente centrifugadas a $10.000 \mathrm{~g}$ por 10 minutos a $4^{\circ} \mathrm{C}$, os sobrenadantes foram descartados e os precipitados insolúveis foram ressuspendidos em tampão $B$ (Tris $\mathrm{HCl} 0,1 \mathrm{M}, \mathrm{pH}$ 7,5, $5 \mathrm{mM}$ de EDTA e 0,1\% de deoxicolato de sódio). As suspensões foram novamente sonicadas e centrifugadas nas mesmas condições descritas anteriormente. $\mathrm{O}$ procedimento de lavagem dos $\mathrm{Cl}$ foi repetido mais uma vez. Após a lavagem, os $\mathrm{Cl}$ foram ressuspedidos em tampão de renaturação (Tris $\mathrm{HCl}$ $50 \mathrm{mM}, \mathrm{pH}$ 7,5 e $1 \mathrm{mM}$ EDTA). A suspensão foi sonicada e centrifugada. Este procedimento foi repetido por mais duas vezes, os $\mathrm{Cl}$ foram ressuspedidos em 10 $\mathrm{mL}$ de tampão de renaturação e armazenados a $-20^{\circ} \mathrm{C}$. 


\subsubsection{Solubilização dos $\mathrm{Cl}$}

As suspensões dos $\mathrm{Cl}$ das proteínas estudadas, produzidas em diferentes temperaturas (eGFP: $37^{\circ} \mathrm{C}, 42^{\circ} \mathrm{C}$ e $47^{\circ} \mathrm{C}$; PilB, gene XAC2810 e gene XAC3272: $20^{\circ} \mathrm{C}, 25^{\circ} \mathrm{C}, 30^{\circ} \mathrm{C}$ e $37^{\circ} \mathrm{C}$ ), foram ajustadas para uma D.O. de 0,5 (A $\left.350 \mathrm{~nm}\right)$ e diluídas em tampão de renaturação contendo concentrações de $\mathrm{Gdn} \mathrm{HCl}$ de 0 a 6 M. As reações foram mantidas sob agitação constante durante 72 horas em temperatura ambiente. $\mathrm{O}$ efeito do agente desnaturante na solubilização dos $\mathrm{Cl}$ foi monitorado pelas mudanças de absorbância a $350 \mathrm{~nm}$ (turbidez) em um espectrofotômetro.

\subsubsection{Pressurização dos $\mathrm{Cl}$}

Suspensões de $\mathrm{Cl}$ de eGFP foram ressuspendidos em tampão de renaturação, ajustando-se as densidades ópticas em espectrofotômetro em comprimento de onda de $350 \mathrm{~nm}$ para uma D.O. = 0,5. A amostra foi colocada em bulbos de pipetas Pasteur de $5 \mathrm{~mL}$, para garantir que um volume fixo de ar $(2 \mathrm{~mL})$ estivesse presente nas amostras da suspensão dos $\mathrm{Cl}$, para promover a oxigenação, importante para a formação do cromóforo responsável pela emissão da luz fluorescente. Os bulbos foram selados a quente e colocados em um único saco plástico, que foi selado à vácuo.

$\mathrm{Cl}$ de PilB e de produtos dos genes XAC2810 e XAC3272 foram resuspendidos em tampão de renaturação com uma D. $0.350 \mathrm{~nm}=2,0$. As amostras foram colocadas em saquinhos plásticos que foram selados. Os saquinhos foram introduzidos em um único saco plástico maior, o qual foi selado a vácuo. Os sacos plásticos foram então colocados no vaso de pressão (Figura 9) e submersos em uma mistura de água e óleo. O vaso foi fechado e pressurizado a 2,4 kbar utilizando um compressor de ar ligado a uma bomba capaz de injetar óleo sob alta pressão no vaso de pressão. As amostras foram submetidas a diversas condições de compressão/descompressão (Tabela 3). Após a descompressão, as amostras foram retiradas dos recipientes plásticos e centrifugadas a $12.000 \mathrm{~g}$ por 15 minutos para a remoção de agregados insolúveis. Os sobrenadantes foram 
dialisados contra tampão Tris $\mathrm{HCl} 50 \mathrm{mM}, \mathrm{pH} 7,5$ e centrifugados novamente para a remoção de agregados. As frações solúveis foram estocadas a $-20^{\circ} \mathrm{C}$ para posterior análise.

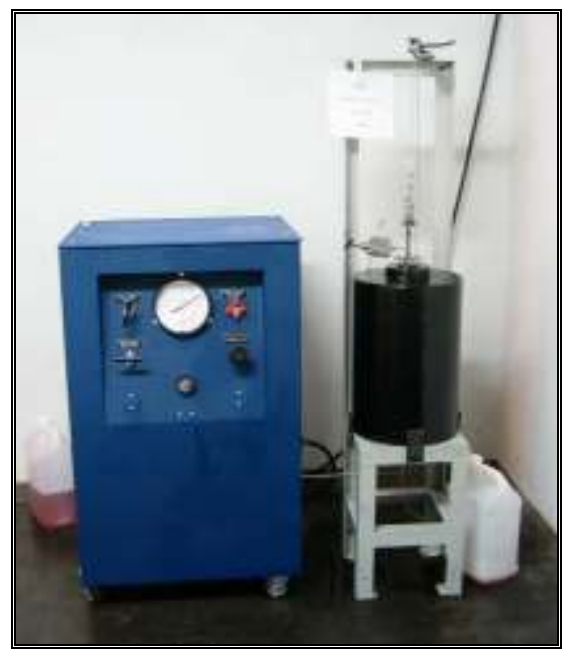

Figura 9. Bomba e vaso de pressão.

Tabela 3. Esquemas de Compressão e Descompressão.

\begin{tabular}{|c|c|}
\hline Condição & Esquema de Pressão/Descompressão \\
\hline A & $\begin{array}{l}2,4 \text { kbar por } 1,5 \text { horas, descompressão direta e } \\
\text { incubação em pressão atmosférica por } 16 \text { horas }\end{array}$ \\
\hline B & 2,4 kbar por 16 horas e descompressão direta \\
\hline C & $\begin{array}{l}2,4 \text { kbar por 1,5 horas, descompressão em degraus e } \\
\text { incubação em pressão atmosférica por } 16 \text { horas }\end{array}$ \\
\hline D & $\begin{array}{c}2,4 \text { kbar por } 1,5 \text { horas, descompressão para 0,8 kbar por } \\
16 \text { horas e descompressão direta }\end{array}$ \\
\hline$E$ & $\begin{array}{c}2,4 \text { kbar por 1,5 horas, descompressão para 0,4 kbar por } \\
16 \text { horas e descompressão direta }\end{array}$ \\
\hline $\mathrm{F}$ & $\begin{array}{c}2,4 \text { kbar por } 1,5 \text { horas, descompressão para 0,2 kbar por } \\
16 \text { horas e descompressão direta. }\end{array}$ \\
\hline
\end{tabular}




\subsubsection{Agentes de óxido-redução}

$\mathrm{O}$ agente redutor Ditiotreitol (DTT) foi adicionado às suspensões de $\mathrm{Cl}$ de eGFP (1 mM). Em suspensões de $\mathrm{Cl}$ das proteínas PilB e produto dos genes XAC2810 e XAC3272 foi adicionado um par óxido-redutor no tampão de renaturação. Os reagentes glutationas reduzida (GSH) e oxidada (GSSG) em uma concentração total de $10 \mathrm{mM}$ foram utilizados como par óxido-redutor e as proporções de cada uma das glutationas foram variadas e na presença de 1,5 M de Gdn HCl. As proporções de GSH e GSSG testadas foram respectivamente: $1: 9 ; 1: 4 ; 1: 2 ; 2: 3 ; 1: 1 ; 3: 2 ; 2: 1 ; 4: 1$ e 9:1. Como controles utilizaram-se suspensões na ausência das glutationas e $\mathrm{Gdn} \mathrm{HCl}$, amostra na ausência de glutationas e amostra com os agentes de óxido-redução e $\mathrm{Gdn} \mathrm{HCl}$ na qual não foi aplicada alta pressão. Os sobrenadantes das amostras pressurizadas na presença de glutationas e $\mathrm{Gdn} \mathrm{HCl}$ foram dialisados contra tampão Tris $\mathrm{HCl} 50$ $\mathrm{mM}, \mathrm{pH}$ 7,5 e $50 \mathrm{mM}$ de $\mathrm{NaCl}$, para a remoção destes reagentes, centrifugados e congelados para posterior análise.

\subsubsection{Agente solubilizante}

Com a prévia seleção dos agentes de óxido-redução, suspensões de $\mathrm{Cl}$ das proteínas PilB e produto dos genes XAC2810 e XAC3272 foram submetidas à alta pressão na presença de concentrações diferentes de $\mathrm{Gdn} \mathrm{HCl}(0,0,5,1,0$ e $1,5 \mathrm{M})$ e a amostra controle na qual não foi aplicada alta pressão também foi utilizada. Os sobrenadantes das amostras foram submetidos à diálise contra tampão Tris $\mathrm{HCl} 50 \mathrm{mM}$, pH 7,5 e $50 \mathrm{mM}$ de $\mathrm{NaCl}$, novamente centrifugados e congelados para posterior análise.

\subsubsection{Aditivos}

A utilidade da presença de aditivos para elevar o rendimento de renaturação das proteínas PilB e produto dos genes XAC2810 e XAC3272 foi 
testada, submetendo amostras de $\mathrm{Cl}$ à alta pressão hidrostática na presença de diferentes aditivos. Os aditivos testados foram os que são descritos como úteis para elevar os rendimentos de renaturação em pressão atmosférica (Jensen and Carlsen 1990; Tsien 1998): $\mathrm{NaCl}$ (0,15 M), L-Arginina (0,5 M), L-Arginina com GdnHCl (1,5 M), Glicose (1 M), Sacarose (1 M), PEG-6000 (0,1\%), Glicerol (2,5 M), Tween 20 (1 mM), Tritron X-100 (0,5 mM) e Bis-ANS (10 vezes a concentração molar de cada proteína). Como controle foi utilizada a suspensão de $\mathrm{Cl}$ na ausência destes aditivos e também uma amostra na qual não foi aplicada alta pressão hidrostática. Os sobrenadantes das amostras foram dialisados contra tampão Tris $\mathrm{HCl} 50 \mathrm{mM}$, pH 7,5 e 50 mM de $\mathrm{NaCl}$, centrifugados e congelados para posterior análise.

\subsubsection{Eletroforese em Gel de Poliacrilamida (SDS-PAGE)}

As análises das amostras solubilizadas pelo tratamento sob pressão e suspensões de $\mathrm{Cl}$ foram realizadas utilizando eletroforese em gel de poliacrilamida (SDS-PAGE) em condições redutoras. As corridas eletroforéticas foram realizadas seguindo o protocolo de Laemmli (1970), utilizando géis de eletroforese de $12 \%$ de concentração. Nas amostras foram adicionados o tampão de amostra e DTT na concentração de $0,1 \mathrm{M}$, as amostras então foram aquecidas a $75^{\circ} \mathrm{C}$ durante 5 minutos, e aplicadas no gel de eletroforese. A corrida foi realizada no tampão de corrida $1 \times(14,4 \mathrm{~g}$ de Glicina, $3 \mathrm{~g}$ de Tris e $1 \mathrm{~g}$ de SDS e água destilada até o volume de $1000 \mathrm{~mL}$ ) e fixando-se a voltagem em $90 \mathrm{~V}$, com a corrente livre.

Finalizada a corrida, os géis foram corados com Comassie Blue G-250 e as bandas puderam ser visualizadas e fotografadas. A análise das bandas nas fotografias dos géis de eletroforese foi realizada utilizando-se o programa Image J. A quantificação das proteínas de interesse foi realizada pela comparação com uma curva padrão de soroalbumina bovina pura. A determinação da porcentagem de solubilização de cada amostra foi realizada pela comparação da banda obtida com a banda referente à suspensão de $\mathrm{Cl}$. 


\subsubsection{Medidas de fluorescência e de espalhamento de luz (EL)}

As medidas de $E L$ e de fluorescência foram realizadas em um espectrofotômetro Cary Eclipse (Varian). A determinação da fluorescência característica de eGFP foi realizada com um comprimento de excitação de 470 $\mathrm{nm}$ e leituras em $509 \mathrm{~nm}$. O comprimento de onda utilizado para a análise da fluorescência dos $\mathrm{Cl}$ foi menor $(440 \mathrm{~nm})$ de maneira a diminuir a alta interferência exercida pelos $\mathrm{Cl}$ no espectro devido ao alto grau de espalhamento da luz de excitação. O espectro de emissão foi coletado entre 450 e 600 nm em um ângulo de $90^{\circ}$ relativo à luz incidente, utilizando um tempo de resposta de $1 \mathrm{~s}$ e uma velocidade de leitura de $240 \mathrm{~nm} /$ minuto. Para o EL, as amostras foram excitadas em $320 \mathrm{~nm}$ e as leituras foram de 315 a $325 \mathrm{~nm}$ em um ângulo de $90^{\circ}$ relativo à luz incidente.

Os dados em pressão atmosférica foram coletados utilizando uma cubeta com $1 \mathrm{~cm}$ de caminho óptico. Para o monitoramento sob pressão, uma célula de alta pressão equipada com janelas de safira (ISS) foi conectada por tubo de aço resistente à pressão a um gerador de pressão (High Pressure Equipment) e etanol foi utilizado como líquido para a transmissão de pressão (figura 10). Neste caso, cubetas redondas preenchidas com as amostras e seladas com tampas flexíveis de polietileno (figura 11) foram colocadas na célula de alta pressão e submetidas à pressão. 


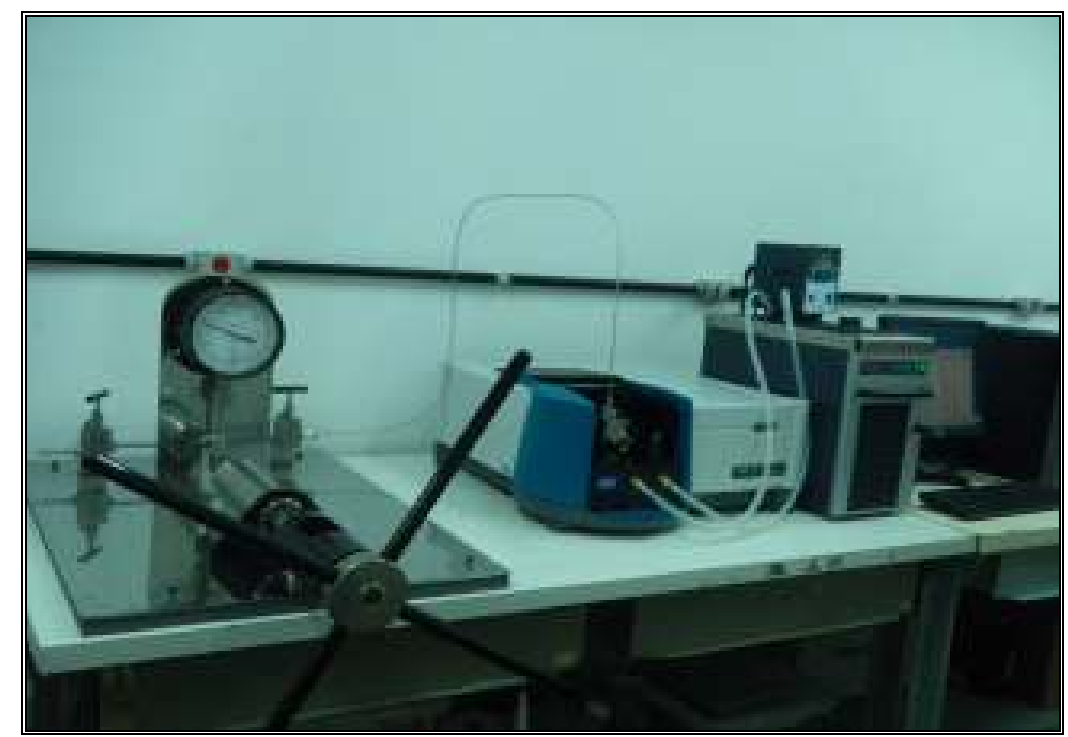

Figura 10. Espectrofluorímetro acoplado a uma célula de pressão, gerador de pressão, e banho termostatizado.

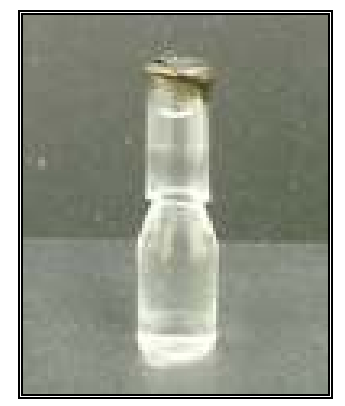

Figura 11. Cubeta de quartzo selada com tampa flexível de silicone.

\subsubsection{Dissociação dos $\mathrm{Cl}$ sob alta pressão hidrostática e temperaturas negativas}

A dissociação dos $\mathrm{Cl}$ sob alta pressão hidrostática associada à aplicação de baixas temperaturas foi avaliada pela queda nos valores de EL. Estas medidas foram obtidas em espectrofluorímetro acoplado a um gerador de pressão e a uma célula de pressão acoplada a um banho-maria termostatizado (Figura 10). As suspensões de $\mathrm{Cl}$ foram submetidas a 2,4 kbar de pressão com intervalos de 0,4 kbar a $20^{\circ} \mathrm{C}$, sendo que em cada intervalo de pressão as amostras foram mantidas durante 15 minutos (tempo suficiente para que a leitura de EL estivesse estabilizada). Após a chegada a 2,4 kbar de pressão, a temperatura foi gradualmente diminuída de $20^{\circ} \mathrm{C}$ até $-9^{\circ} \mathrm{C}$ também sendo mantidas nas 
temperaturas selecionadas durante 15 minutos, e por fim a temperatura foi elevada a $20^{\circ} \mathrm{C}$ e foi realizada a descompressão até a pressão atmosférica. As leituras de EL foram realizadas em cada intervalo tanto de pressão, quanto de temperatura.

\subsubsection{Microscopia eletrônica de varredura (MEV)}

A magnitude de desagregação e possíveis mudanças no tamanho e morfologia dos $\mathrm{Cl}$ à ação da pressão (2,4 kbar) foram visualizadas por MEV. Para tal análise, suspensões de $\mathrm{Cl}$ não submetidas à alta pressão e também as frações insolúveis de amostras já submetidas à alta pressão foram lavados com água destilada para a retirada do Tris $\mathrm{HCl}$ da solução tampão. Após a lavagem, os precipitados foram aplicados em porta-amostras e secos em dessecador durante 16 horas. As amostras receberam um banho de ouro a $38 \mathrm{~mA}$ por 120 segundos e foram visualizadas e fotografadas em microscópio eletrônico de varredura Philips XL-200 operando a $15 \mathrm{kV}$. Os tamanhos dos $\mathrm{Cl}$ foram analisados utilizando o software Image Tools.

\subsubsection{Espectroscopia de infravermelho (FT-IR)}

Espectros de infravermelho com transformada de Fourier (Fourier Transform Infrared Spectroscopy, FT-IR), com reflectância total atenuada (ATR) foram obtidos de amostras secas depositadas diretamente no cristal de ATR em um espetrômetro de infravermelho Nicolet 6700 (Thermo Corp., USA). Os espectros foram coletados com uma resolução de $4 \mathrm{~cm}^{-1}$ e foram o resultado de um acúmulo de 256 varreduras. 


\subsubsection{Purificação por cromatografia de afinidade por metais imobilizados}

A proteína eGFP solúvel e nativa e as outras proteínas solubilizadas sob alta pressão (PilB e os produtos dos genes XAC2810 e XAC3272) foram submetidas à purificação por cromatografia de afinidade utilizando uma coluna de níquel His Trap HP (GE Healthcare) de $1 \mathrm{~mL}$ carregada com sulfato de níquel $\left(\mathrm{NiSO}_{4}\right)$. O fluxo utilizado foi de $1 \mathrm{~mL}$ por minuto e a coluna foi pré-lavada com no mínimo 5 volumes de tampão Tris $\mathrm{HCl} 50 \mathrm{mM}, \mathrm{pH} 7,5$ contendo $0,5 \mathrm{M}$ de $\mathrm{NaCl}$ e $20 \mathrm{mM}$ de Imidazol. As amostras, no mesmo tampão, foram aplicadas na coluna de purificação. A resina foi lavada com 5 volumes do tampão contendo Tris $\mathrm{HCl}$ $50 \mathrm{mM}, \mathrm{pH} 7,5$ contendo $0,5 \mathrm{M}$ de $\mathrm{NaCl}$ e $60 \mathrm{mM}$ de Imidazol para retirar ligantes fracos ou proteínas que não se ligaram à matriz. As proteínas foram eluídas em um volume do mesmo tampão contendo $500 \mathrm{mM}$ de Imidazol e posteriormente dialisadas em Tris HCl 50 mM, pH 7,5 (eGFP) e Tris HCl 50 mM, pH 7,5 e 50 mM de $\mathrm{NaCl}$ (PilB e produtos dos genes XAC2810 e XAC3272). As amostras resultantes foram quantificadas por eletroforese em gel de poliacrilamida, utilizando-se como padrão uma curva padrão de soroalbumina bovina. A proteína eGFP produzida na forma solúvel e purificada foi utilizada para determinação de fluorescência específica.

\subsubsection{Cálculo das taxas de constantes de aquisição de fluorescência}

As constantes Kenovelamento/maturação foram calculadas pelo ajuste das curvas de aquisição de fluorescência utilizando a seguinte equação:

$$
I(t)=I(\infty)[1-\exp (-k . t)]
$$

Aonde $\mathrm{I}(\mathrm{t})$ e $\mathrm{I}(\infty)$ são as intensidades de fluorescência no tempo t e no tempo infinito, respectivamente e k é a taxa constante de renaturação (lizuka, Yamagishi-Shirasaki et al. 2011). Os dados foram calculados utilizando o programa Prism 5. 


\subsubsection{Caracterização das proteínas solúveis PilB e produtos dos genes XAC2810 e XAC3272 por cromatografia de exclusão molecular}

Amostras da proteína PilB e dos produtos dos genes XAC2810 e XAC3272 solúveis após aplicação de alta pressão hidrostática foram analisadas e caracterizadas por cromatografia de exclusão molecular, utilizando uma coluna Superdex 200 (GE Healthcare) de 220 mL, em um equipamento ÄKTA purifier (GE Healthcare), com um fluxo de $0,5 \mathrm{~mL} / \mathrm{min}$. e a absorbância foi medida em 280 $\mathrm{nm}$.

\subsubsection{Análise de atividade biológica das proteínas renaturadas sob alta pressão hidrostática}

\subsubsection{Análise de atividade biológica de eGFP}

A atividade biológica da eGFP foi determinada pela intensidade da fluorescência.

\subsubsection{Análise de atividade biológica de PilB}

A atividade biológica da proteína PilB foi determinada pelo ensaio de hidrólise de ATP monitorada por espectrofotometria utilizando o kit de ensaio de fosfato EnzChek ${ }^{\circledR}$ (Invitrogen). O fosfato inorgânico liberado da hidrólise de ATP e 2-amino-6-mercapto-7-metilpurina ribosideo (MESG) é convetido por purina fosforilase (PNP) para ribose 1-fosfato e 2-amino-6-mercapto-7-metilpurina, o que resulta em uma mudança de absorbância em comprimentos de onda entre $330 \mathrm{e}$ $360 \mathrm{~nm}$. O ensaio foi realizado em triplicata. A mistura da reação continha $76 \mu \mathrm{g}$ de proteína purificada em $25 \mu \mathrm{L}$ de tampão (Tris HCl 50 mM, pH 7,5 e 1,25 mM $\mathrm{MgCl}_{2}$ ), 0,2 mM de MESG, $1 \mathrm{U}$ de PNP e $1 \mathrm{mM}$ de ATP em um volume total de 1 $\mathrm{mL}$. Após incubação durante 30 minutos a $24^{\circ} \mathrm{C}$ a absorbância foi determinada em 
$360 \mathrm{~nm}$. Os resultados foram normalizados subtraindo a leitura da amostra controle, na qual não continha ATPase. Como controle negativo foi utilizada amostra na ausência de ATP. A quantidade total de fosfato liberado foi determinada por comparação da absorbância da amostra de proteína com uma curva padrão de fosfato (1,25 - $10 \mu \mathrm{M}$ de fosfato inorgânico) (Chiang, Sampaleanu et al. 2008).

\subsubsection{Análise de atividade biológica dos produtos dos genes XAC2810 e XAC3272}

Para verificar a atividade de diguanilato ciclase (produtos dos genes XAC2810 e XAC3272 com domínio GGDEF conservado), utilizam-se normalmente ensaios que quantificam fosfato inorgânico e para isso é necessário acrescentar uma pirofosfatase no meio reacional. A pirofosfatase converte 0 pirofosfato liberado pela ação da diguanilato ciclase sobre o GTP em 2 moléculas de fosfato livres. O fosfato livre pode ser quantificado pela mudança de absorbância da reação com a solução de verde malaquita e molibdato de amônio. O ensaio foi realizado em triplicata. A mistura da reação continha 65 e $72 \mu \mathrm{g}$ de proteína purificada (produtos dos genes XAC2810 e XAC3272, respectivamente), $100 \mu \mathrm{L}$ do tampão (2 mM de $\mathrm{MgCl}_{2}$, Tris $\mathrm{HCl} 20 \mathrm{mM}, \mathrm{pH}$ 7,5 e $100 \mathrm{mM}$ de $\mathrm{NaCl}$ ), $500 \mathrm{mUN}$ de pirofosfatase e $1 \mathrm{mM}$ de GTP em um volume final de $1 \mathrm{~mL}$. Após incubação durante 2 horas a $30^{\circ} \mathrm{C}$ a reação foi inativada pela adição de $200 \mu \mathrm{L}$ da solução 1 de Verde Malaquita (0,045\%) para 3 de molibdato de amônio (4,2\% em 4N HCl), e 0,0001\% de Triton X-100. Esta solução foi preparada uma hora antes do uso, mantida em temperatura ambiente, no escuro e foi filtrada em filtro com poros de 0,22 $\mu \mathrm{m}$ antes do uso. A absorbância foi determinada em $650 \mathrm{~nm}$. Os resultados foram normalizados subtraindo-se a leitura da amostra controle, na qual não continha proteína ou fosfato livre. Como controle negativo foi utilizada amostra na ausência de GTP. A quantidade total de fosfato liberado foi então determinada por comparação da absorbância da amostra de proteína normalizada a uma curva padrão de fosfato (1,25 - $20 \mu \mathrm{M}$ de fosfato inorgânico) (Chan, Paul et al. 2004). 


\section{RESULTADOS E DISCUSSÃO}

\subsection{Proteína verde fluorescente (GFP)}

\subsubsection{Dissociação dos $\mathrm{Cl}$ utilizando alta pressão hidrostática}

A alta pressão hidrostática tem se mostrado uma ferramenta muito eficiente na dissociação de $\mathrm{Cl}$, com vantagem sobre a solubilização de agregados utilizando agentes desnaturantes, pois no caso da utilização de pressões abaixo de $5 \mathrm{kbar}$ as estruturas secundária e terciária são geralmente mantidas (Przybycien, Dunn et al. 1994; Ami, Natalello et al. 2006; de Groot and Ventura 2006; Garcia-Fruitos, Aris et al. 2007; Peternel, Grdadolnik et al. 2008). Para determinar o efeito da alta pressão hidrostática na dissociação dos $\mathrm{Cl}$, as suspensões de $\mathrm{Cl}$ de eGFP foram submetidas a uma pressão de $2,4 \mathrm{kbar}\left(20^{\circ} \mathrm{C}\right)$ e o EL foi avaliado durante 60 minutos (figura 12 A). Após 25 minutos da aplicação da pressão, houve a estabilização, com um decréscimo de $79 \%$ no valor de EL quando comparado com o valor inicial, o que indica a dissociação dos $\mathrm{Cl}$. Após a descompressão para pressão atmosférica, o valor do EL não retornou ao valor original, indicando irreversibilidade da dissociação induzida pela pressão. Dados da literatura demonstram que a aplicação de altas pressões (1 - 3 kbar) é capaz de dissociar agregados de proteínas (Silva and Weber 1993; Bonafe, Araujo et al. 1994; Schoner, Bramlett et al. 2005), por promover o rompimento de interações inter-moleculares, induzindo a dissociação dos agregados. A aplicação de 2,4 kbar durante 30 minutos foi utilizada nos experimentos subseqüentes para dissociar os $\mathrm{Cl}$ de eGFP.

Corroborando os resultados de EL, as fotografias das suspensões de $\mathrm{Cl}$, realizadas em microscópio eletrônico de varredura demonstram que houve uma diminuição drástica na quantidade de $\mathrm{Cl}$ nas amostras submetidas a 2,4 kbar durante 30 minutos (figura $12 \mathrm{~B}$ e C). Os $\mathrm{Cl}$ consistem em partículas esféricas regulares em média $0,8 \pm 0,1 \mu \mathrm{m}$ de diâmetro. A média do diâmetro das partículas insolúveis de amostras submetidas à alta pressão foi de 0,5 $\pm 0,1 \mu \mathrm{m}$, representando um decréscimo de $39 \%$ no tamanho. Esses resultados sugerem 
que os agregados que resistiram ao tratamento em alta pressão, são estruturas que possivelmente foram compactadas pela ação da pressão.

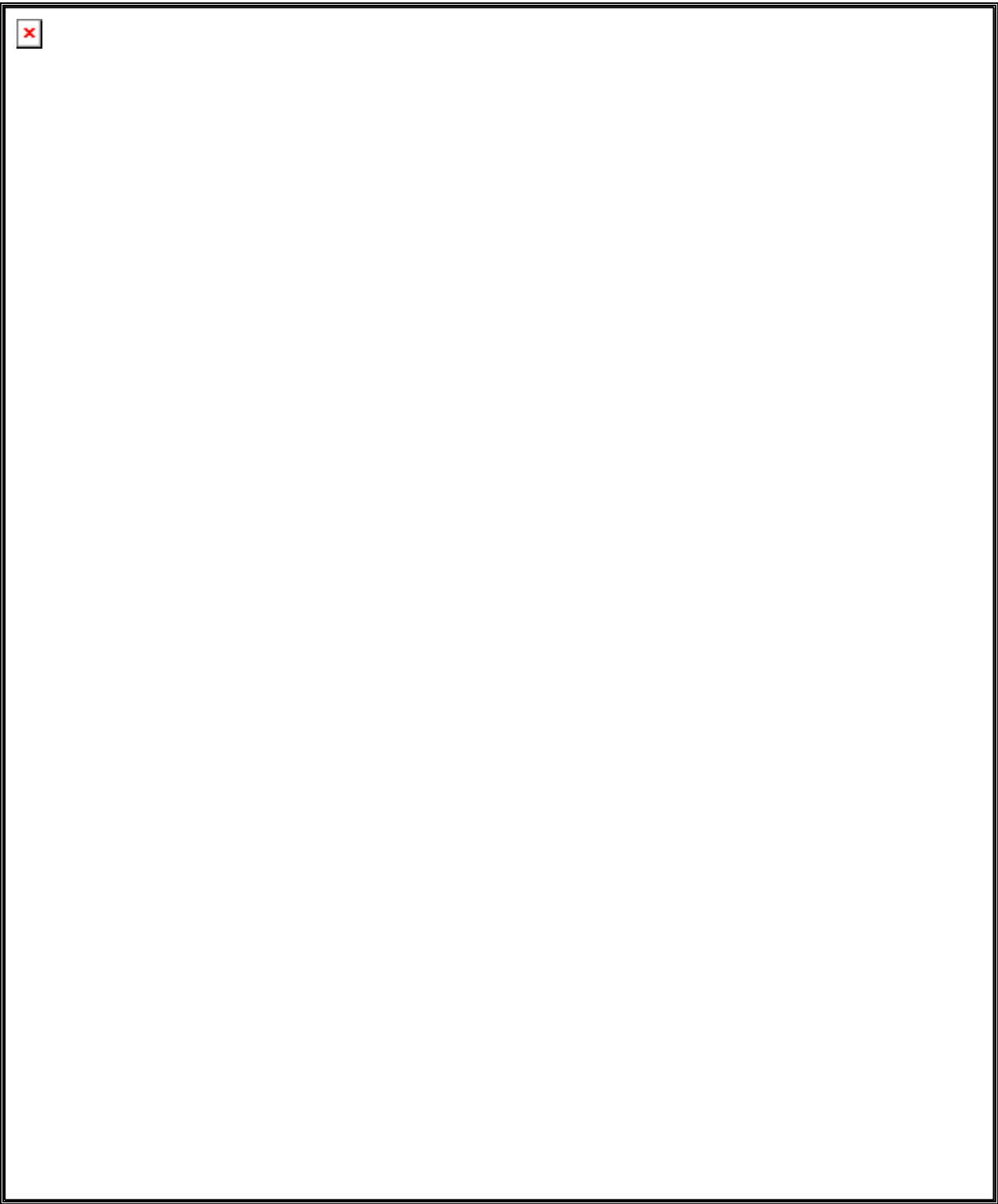

Figura 12. Efeito da alta pressão na dissociação de $\mathrm{Cl}$ de eGFP. A. Espalhamento de luz (excitação em $320 \mathrm{~nm}$, varredura entre 300 e $350 \mathrm{~nm}$ ) de suspensão de $\mathrm{Cl}$ submetida a pressão de $2,4 \mathrm{kbar}$ a $20^{\circ} \mathrm{C}$ em função do tempo, $\boldsymbol{\Delta}$ corresponde ao EL após a descompressão para pressão atmosférica; B. MEV de suspensão de $\mathrm{Cl}$ não submetidos a alta pressão; C. MEV de suspensão de $\mathrm{Cl}$ após o tratamento com alta pressão hidrostática. Barras de escala $20 \mu \mathrm{m}$ (aumento - 1000X) e $2 \mu \mathrm{m}$ (aumento - 10.000X). 


\subsubsection{Renaturação de Cl de eGFP sob alta pressão hidrostática}

Após a renaturação, a eGFP sofre autocatálise e forma o cromóforo que emite fluorescência na região verde $(509 \mathrm{~nm})$, daí o nome dado à esta proteína. $\mathrm{O}$ processo de renaturação da eGFP foi monitorado pela determinação da intensidade de fluorescência em $509 \mathrm{~nm}$.

A intensidade da fluorescência da suspensão de Cl de eGFP em 509 nm é baixa, indicando que a maioria das proteínas presentes nos $\mathrm{Cl}$ de eGFP não se apresentam na sua conformação correta (Inset figura $13 \mathrm{~A}$ - linha contínua). $\mathrm{O}$ fato de que a intensidade da fluorescência verde (em 509 nm) se mantém constante durante a aplicação de uma pressão de 2,4 kbar a uma suspensão de $\mathrm{Cl}$ de eGFP indica que a renaturação e a maturação do cromóforo não ocorrem nestas condições. No entanto, quando uma amostra de $\mathrm{Cl}$ submetida à pressão de 2,4 kbar foi submetida à descompressão direta até a pressão atmosférica, se observa uma elevação na intensidade de fluorescência de 37 vezes (figura $13 \mathrm{~A}$ círculos). Alguns artigos sobre a renaturação de proteínas utilizando alta pressão propõem que a renaturação das proteínas ocorre em pressões da ordem de 1 a 3 kbar (St John, Carpenter et al. 1999; St John, Carpenter et al. 2001; St John, Carpenter et al. 2002). Além disso, o mesmo grupo de autores também sugere que a descompressão lenta poderia melhorar o rendimento de renaturação das proteínas, pois a despressurização rápida poderia resultar na formação de espécies não nativas e propensas à agregação. Com base nesta idéia, e com o objetivo de aumentar o rendimento de renaturação de eGFP, o efeito da descompressão em degraus foi monitorado pela medida da emissão de fluorescência em $509 \mathrm{~nm}$. A primeira estratégia foi submeter amostras de $\mathrm{Cl}$ a 2,4 kbar durante 30 minutos, seguido por descompressão em degraus de 0,4 kbar, mantendo a proteína por 30 minutos em cada nível de pressão até a completa descompressão para a pressão atmosférica (figura $13 \mathrm{~A}$ - quadrados). Surpreendentemente, a intensidade de fluorescência em $509 \mathrm{~nm}$ aumentou gradualmente a partir de 1,38 kbar de pressão até a chegada a pressão atmosférica (figura $13 \mathrm{~A}$ ). Um aumento de 40 vezes na fluorescência foi observado quando esta estratégia foi utilizada, o que resultou em um aumento de 80 vezes após incubação em pressão atmosférica (Inset, figura 13 A). 
Devido ao fato de que a renaturação de eGFP foi favorecida em níveis menores do que 1,38 kbar de pressão, nos perguntamos se seria possível melhorar ainda mais o rendimento de renaturação da proteína, pela incubação durante tempos maiores da proteína em pressões intermediárias antes da completa descompressão para pressão atmosférica. Para testar esta hipótese, $\mathrm{Cl}$ de eGFP foram submetidos à pressão de 2,4 kbar por 30 minutos e em seguida foi realizada a descompressão direta para $0,69 \mathrm{kbar}$, com manutenção da amostra nesta pressão 16 horas antes da descompressão para pressão atmosférica (figura 13 B - círculos). Sob esta condição, a emissão a 509 nm aumentou 136 vezes, sugerindo maior eficiência na renaturação da proteína eGFP no estado nativo. $\mathrm{O}$ fato de que a intensidade da fluorescência foi mantida mesmo após o retorno à pressão atmosférica também indica que a proteína foi renaturada na pressão de 0,69 kbar. A figura 13 B também demonstra que mesmo quando a descompressão foi realizada em degraus, porém com incubação por 16 horas em 0,69 kbar, antes da completa descompressão para a pressão atmosférica, não foi obtida elevação do rendimento de renaturação de eGFP (figura 13 B - quadrados) na comparação com a condição anterior, de descompressão direta, o que sugere que o fator que teve maior influência na renaturação da eGFP foi a incubação na pressão intermediária e não a descompressão gradual. No inset da figura $13 \mathrm{~B}$ pode-se observar que após 5 horas de incubação em 0,69 kbar, o processo de renaturação atingiu seu valor máximo. A cinética da renaturação da eGFP foi similar em outros níveis de pressão (pressão atmosférica; e pressões intermediárias de 0,4; 1,2 e 1,6 kbar).

Pode-se argumentar que as diferenças nos valores de fluorescência poderiam se dever às variações na cinética na renaturação da eGFP em diferentes pressões, porque em condições mais lentas de renaturação poderia não ter havido tempo suficiente para atingir o equilíbrio e a completa renaturação da proteína eGFP. Esta possibilidade foi excluída por realização de experimentos em prolongados períodos, isto é 72 horas, o que levou a resultados semelhantes aos atingidos em períodos mais curtos (16 horas). 


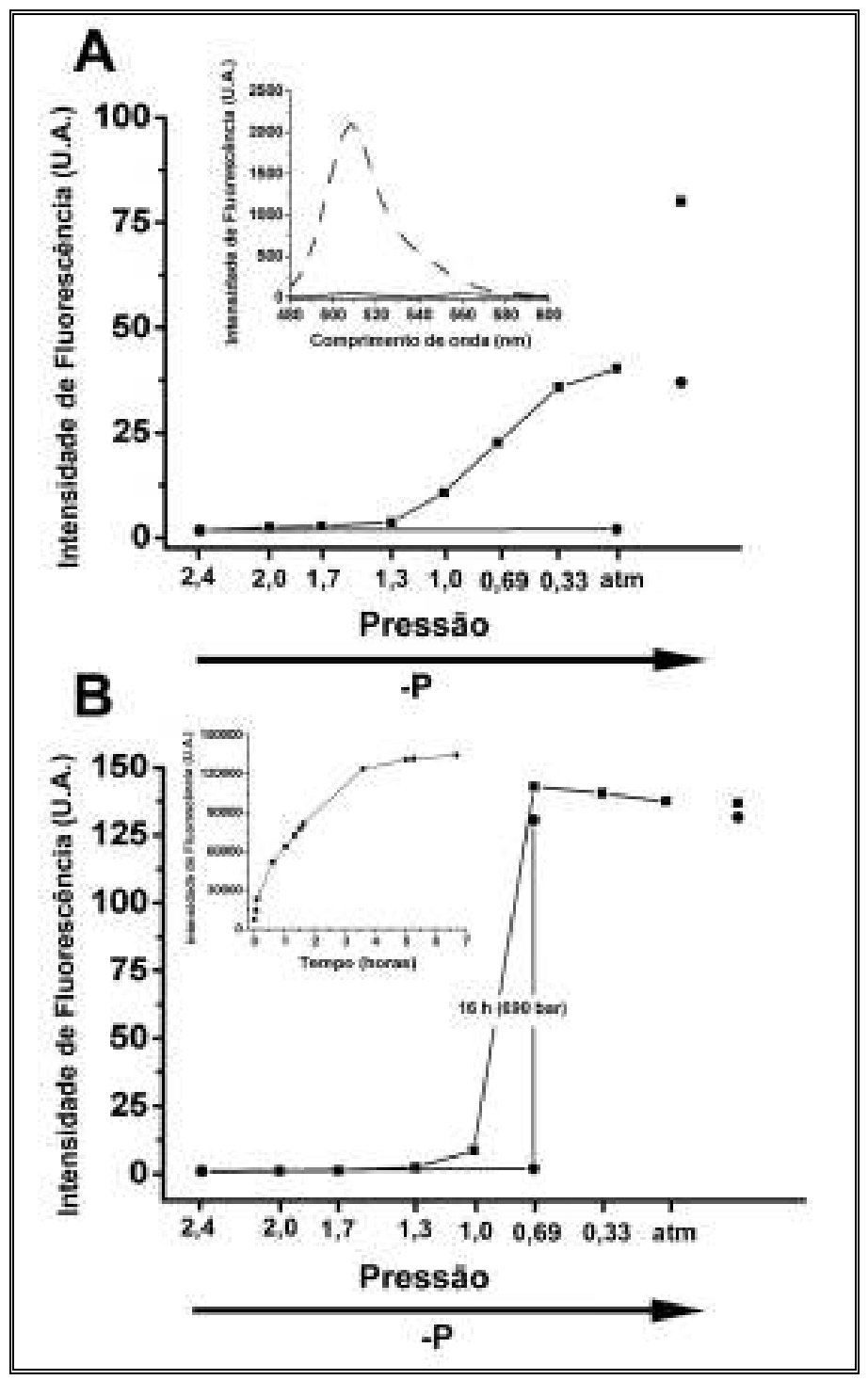

Figura 13. Intensidade de Fluorescência (emissão em 509 nm e excitação em 470 nm) de eGFP renaturada sob diferentes métodos de compressão e descompressão. A. Suspensões de $\mathrm{Cl}$ submetidas à pressão de $2,4 \mathrm{kbar}$, descompressão direta até a pressão atmosférica $(\bullet)$ e descompressão em degraus até a pressão atmosférica (-); Inset: Espectro da intensidade de fluorescência de sobrenadantes de suspensões de $\mathrm{Cl}$ submetidas (linha tracejada) e não submetidas à pressão (linha contínua) de 2,4 kbar durante 30 minutos; B. Suspensão de $\mathrm{Cl}$ submetidas à pressão de $2,4 \mathrm{kbar}$, com descompressão direta $(\bullet)$ e em degraus $(\mathbf{\bullet})$ até a pressão de 0,69 kbar (16 horas) e descompressão até a pressão atmosférica; Inset: Intensidade de Fluorescência com emissão em $509 \mathrm{~nm}$ a partir da pressão $0,69 \mathrm{kbar}$ em função do tempo nesta mesma pressão. Suspensão de $\mathrm{Cl}$ submetidos a 2,4 kbar e descompressão direta para 0,69 kbar.

Devido ao fato de que houve a elevação da recuperação de eGFP nativa quando da incubação de eGFP em 0,69 kbar após a descompressão de 2,4 kbar, nos perguntamos se os valores de pressão maiores ou menores que 0,69 kbar poderiam ser mais eficientes. Na figura 14 observa-se que a descompressão de amostras de $\mathrm{Cl}$ de eGFP diretamente para 1,38, 1,03, 0,69 ou 0,35 kbar resultou 
em obtenção de fluorescência. Contudo, a incubação nas pressões mais elevadas do que 0,69 kbar são menos eficientes na renaturação da eGFP. Resultados semelhantes foram obtidos quando as amostras foram mantidas por períodos ainda mais longos em cada nível de pressão intermediária.

A presença de oxigênio é obrigatória para a maturação do cromóforo (ciclização, oxidação e desidratação), o passo limitante na taxa de renaturação da eGFP (Craggs 2009). Por isso, um experimento controle, no qual bolhas de ar foram deixadas nas amostras de suspensões de $\mathrm{Cl}$ foi realizado e comparado com as amostras submetidas à alta pressão na ausência de ar. Não houve diferença nos rendimentos de fluorescência obtidos neste meio mais oxidante, o que indica que o oxigênio presente nas amostras é suficiente para promover a maturação do cromóforo.

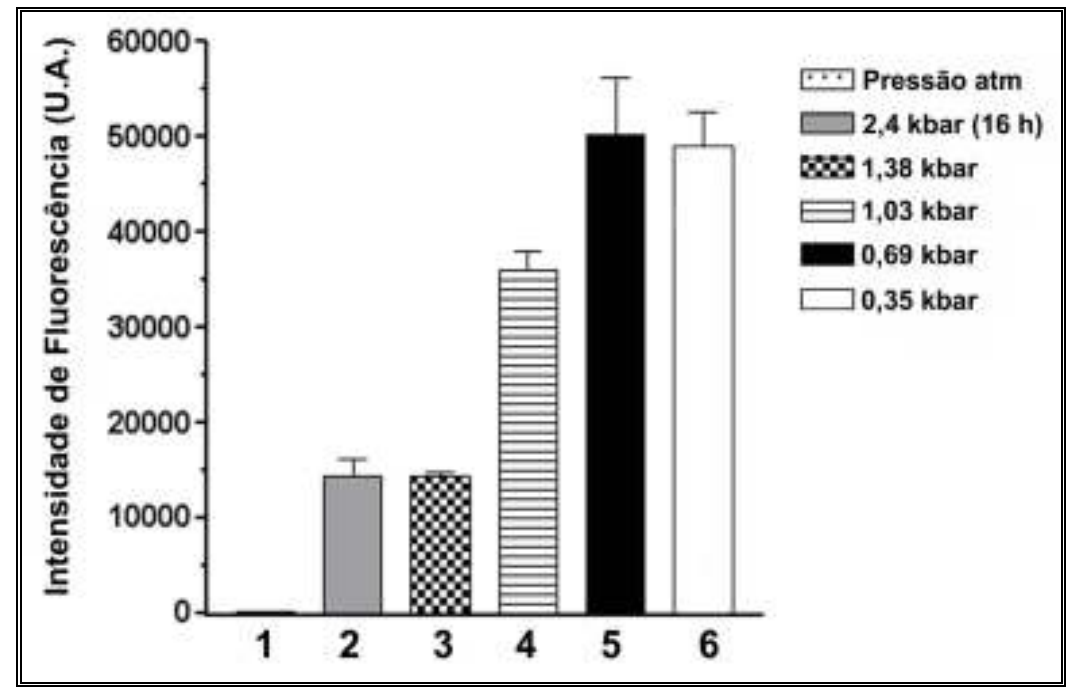

Figura 14. Intensidade de Fluorescência de eGFP a partir de suspensões de $\mathrm{Cl}$ submetidos a 2,4 kbar de pressão utilizando diferentes pressões intermediárias na renaturação. Coluna 1. Amostras de suspensão de $\mathrm{Cl}$ mantidos 16 horas em pressão atmosférica; Coluna 2. Amostras mantidas 16 horas em 2,4 kbar; Colunas 3, 4, 5 e 6. Amostras submetidas a 2,4 kbar durante 30 minutos e descompressão direta para as pressões de 1,38, 1,03,0,69 e 0,35 kbar respectivamente, mantidas nestas pressões 16 horas antes da descompressão total para pressão atmosférica. One-way ANOVA, $p<0,05$.

Estudos relatados na literatura demonstraram a renaturação de uma variedade de proteínas monoméricas, durante a incubação por períodos longos (16 - 125 horas) a pressões de 1,5 - 2,5 kbar. Segundo este grupo de autores, a 
dissociação dos agregados e a renaturação são descritos como se acontecessem simultaneamente no mesmo nível de pressão (Foguel, Robinson et al. 1999; St John, Carpenter et al. 1999; St John, Carpenter et al. 2001; Seefeldt, Ouyang et al. 2004; Schoner, Bramlett et al. 2005; Lee, Carpenter et al. 2006). Os nossos dados mostraram que a renaturação de eGFP não foi favorecida em pressões superiores a 1,4 kbar, apesar de pressões nestes níveis favorecerem a dissociação de agregados de $\mathrm{Cl}$. O uso da eGFP como um modelo permitiu que pudéssemos verificar que a renaturação da eGFP ocorre em níveis menores do que 1,4 kbar, possibilitando que pudéssemos melhorar o protocolo de renaturação de proteínas monoméricas. A análise dos nossos dados sugere que é possível que o aumento no rendimento de renaturação obtido pela descompressão lenta de outras proteínas descritas (Kim, Randolph et al. 2006) esteja relacionado à renaturação, durante a incubação em pressão intermediárias entre 2 kbar e pressão atmosférica.

\subsubsection{Estados renaturados e não renaturados permanecem solúveis após a descompressão}

Quantidades semelhantes de eGFP solúvel foram obtidas para suspensões de $\mathrm{Cl}$ submetidas a 2,4 kbar durante 30 minutos seguida de descompressão utilizando diferentes métodos de descompressão direta ou em degraus com e sem pressão intermediária (Inset figura 15). Para obtermos uma melhor quantificação do processo de renaturação, a fluorescência específica de eGFP foi determinada em diferentes condições de compressão e descompressão (figura 15 A). A descompressão direta para 0,69 kbar seguida pela renaturação da proteína após 16 horas nesta pressão (barra pontilhada) resultou em uma fluorescência 4,6 vezes mais elevada do que aquela obtida para as amostras submetidas à descompressão direta para pressão atmosférica (barra em branco), visualizada pelos valores de fluorescência específica (intensidade de fluorescência em 509 $\mathrm{nm} / \mu \mathrm{g}$ eGFP). Para a proteína eGFP renaturada em 0,69 kbar, foi obtido um rendimento de $75 \%$ de fluorescência específica (barra em listras horizontais) 
quando a intensidade de fluorescência da proteína nativa em relação à concentração proteica foi considerada como $100 \%$.

Uma grande elevação no rendimento de monômeros de eGFP apresentando tempo de retenção de 23,2 minutos (pico de absorbância a $280 \mathrm{~nm}$ - linha contínua, figuras 15 B e 15 C) com alta intensidade de fluorescência a 509 $\mathrm{nm}$ (linha tracejada) foi observada quando a fração solúvel de suspensões de $\mathrm{Cl}$ submetidos a 2,4 kbar e descompressão com incubação em 0,69 kbar foi analisada por cromatografia de exclusão molecular na comparação com amostras de suspensões submetidas a 2,4 kbar e descompressão direta para pressão atmosférica, a qual apresentou o pico de absorbância maior no tempo de retenção de 17,5 minutos, e que possivelmente corresponde a uma espécie de massa molecular maior. Este resultado sugere que após a descompressão direta, estados re-agregados com massa molecular maior do que a eGFP monomérica são produzidos, porém em estado solúvel. 


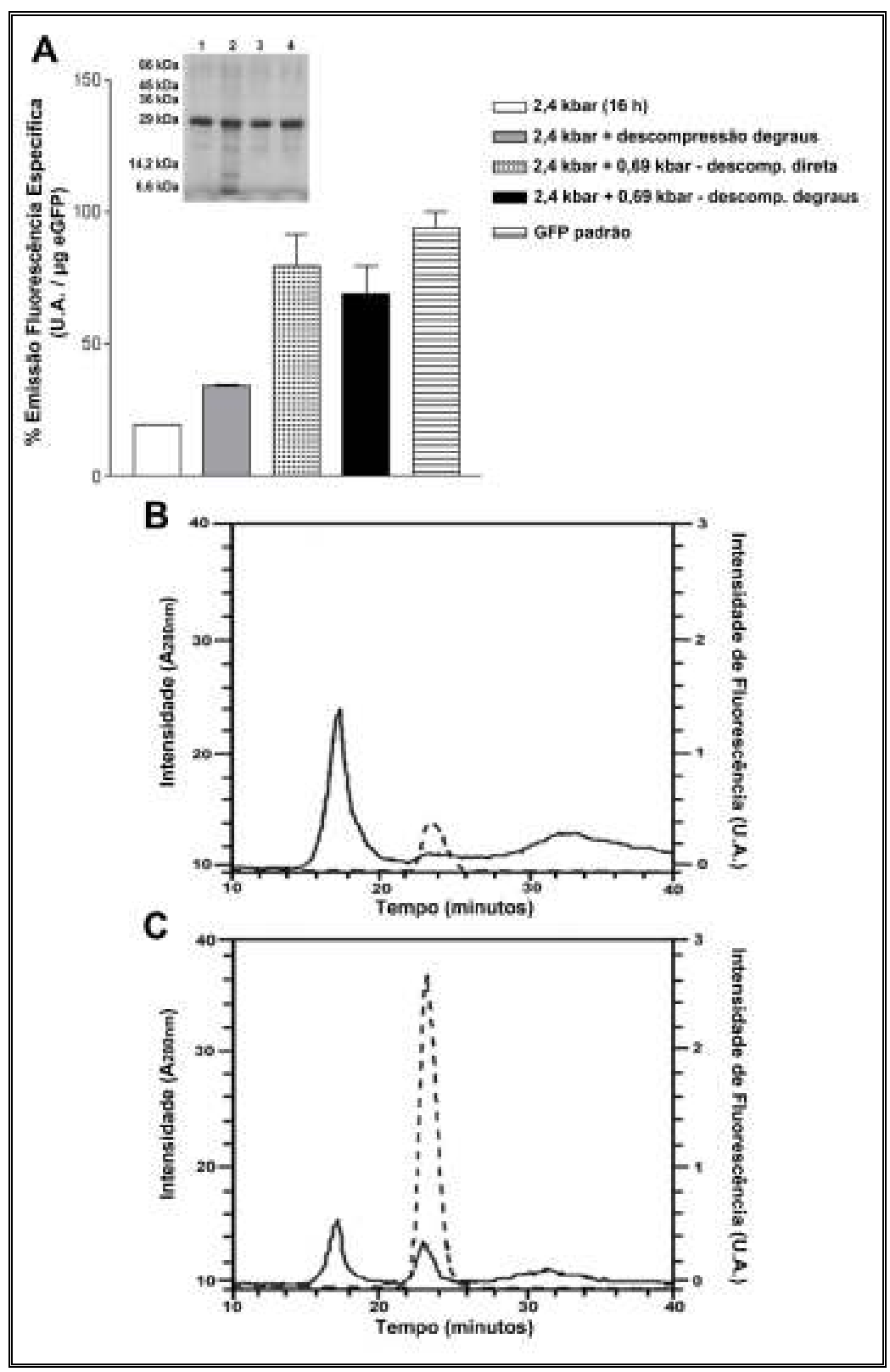

Figura 15. Renaturação e solubilização dos $\mathrm{Cl}$ de eGFP. A. Fluorescência específica (intensidade de fluorescência/ug eGFP) de frações solúveis de Cl submetidos a pressão de 2,4 kbar utilizando diferentes métodos de compressão e descompressão; Inset: Eletroforese em gel de poliacrilamida em condições redutoras. Coluna 1. Descompressão em degraus $(2,4 \mathrm{kbar}$ com intervalos de 0,4 kbar durante 30 minutos em cada intervalo de pressão); coluna 2. 2,4 kbar com descompressão direta para pressão atmosférica; coluna 3. 2,4 kbar com descompressão direta para 0,69 kbar (16 horas) e descompressão direta para pressão atmosférica; coluna 4. 2,4 kbar com descompressão em degraus para 0,69 kbar (16 horas) e descompressão em degraus para pressão atmosférica. $\mathbf{B}$ e C. Espectros de absorbância em $280 \mathrm{~nm}$ (linha contínua) e fluorescência em $509 \mathrm{~nm}$ (com excitação em $470 \mathrm{~nm}$ ) (linha tracejada) em uma coluna de exclusão molecular Superdex 75 10/30 GL (GE). B. fração solúvel de Cl submetidos a 2,4 kbar de pressão e descompressão direta para pressão atmosférica; $\mathbf{C}$. fração solúvel de $\mathrm{Cl}$ submetidos a 2,4 kbar com pressão intermediária em 0,69 kbar durante 16 horas antes da descompressão total para pressão atmosférica. 
As interações entre resíduos de aminoácidos nas estruturas terciária e quaternárias de proteínas são similares (forças de van der Waals, pontes salinas e interações hidrofóbicas) e, portanto, respostas similares à pressão são esperadas. Assim, as estruturas proteicas terciárias e quaternárias são afetadas de forma similar pela ação de alta pressão (Dill 1990; Jaenicke 1991; Jaenicke 1991). A alta pressão é efetiva para desestabilizar as estruturas, promovendo a desnaturação parcial do polipeptídeo para formas menos compactas e dissociação de proteínas oligoméricas e de agregados. Por isso é possível que níveis de pressão que provocam a dissociação de proteínas agregadas possam também afetar as interações envolvidas na manutenção da estrutura terciária. Foi demonstrado por emissão de fosforescência de triptofano, que a aplicação de pressões relativamente baixas ( 1 - 2 kbar) pode induzir a alterações na estrutura terciária de proteínas monoméricas (Cioni and Strambini 1994; Cioni and Strambini 2002), além de mudanças conformacionais que precederam a dissociação de proteínas oligoméricas para monômeros (Cioni and Strambini 1996). Deste modo, a compressão de eGFP em níveis de pressão superiores de 1,4 kbar provavelmente dificulta as interações envolvidas no enovelamento da estrutura da proteína, impedindo assim a renaturação para o estado nativo. A proteína tailspike do fago P22 de Salmonella é uma proteína homotrimérica de adesão viral (Steinbacher, Miller et al. 1997). As vias de renaturação e agregação de tailspike foram bem caracterizadas e a agregação das cadeias ocorre por interações específicas. Em contraste com os resultados descritos pelo grupo do Dr. Randolph para proteínas monoméricas, estudos mostraram que agregados inespecíficos da proteína tailspike são dissociados utilizando o tratamento sob alta pressão (2 kbar durante 90 minutos) apenas renaturam por oligomerização ao estado trimérico nativo, após a descompressão para pressão atmosférica (Foguel, Robinson et al. 1999; Lefebvre and Robinson 2003; Lefebvre, Gage et al. 2004). A rodanase é uma proteína heterodimérica que possui dois domínios independentes de tamanhos aproximadamente iguais, contendo $\alpha$-hélices e folhas- $\beta$ na estrutura secundária. Esses domínios são firmemente ligados um ao outro por ligações não-covalentes, principalmente por interações hidrofóbicas (Hol 1983). A proteína parcialmente desnaturada rapidamente agrega via interações hidrofóbicas entre os domínios. Foi demonstrado que a agregação da rodanase é completamente revertida em 0,5 kbar e a níveis mais elevados de pressão. 0 mesmo nível de 
pressão é também a pressão mínima capaz de evitar a precipitação de estados de rodanase propensos à agregação (Gorovits and Horowitz 1998).

Por estes motivos e também com base em nossos dados, acreditamos que de uma maneira genérica a incubação durante longos períodos de tempos em pressões entre 0,35 e 0,69 kbar após a dissociação dos agregados por aplicação de altas pressões ( 2 - 2,5 kbar) possa ser usado para evitar a re-agregação, enquanto concomitantemente a renaturação a estados nativos seja favorecida para proteínas monoméricas aumentando assim os rendimentos de renaturação. De fato, a utilização de um protocolo semelhante foi muito útil, duplicando o rendimento de renaturação da proteína endostatina a partir de agregados de $\mathrm{Cl}$ (artigo em publicação Chura-Chambi et al. 2013).

\subsubsection{A presença de $\mathrm{Gdn} \mathrm{HCl}$ desfavorece a renaturação de eGFP}

É bastante frequente na literatura sobre a renaturação de proteínas utilizando alta pressão e utilização de concentrações não desnaturantes de Gdn $\mathrm{HCl}$ (Kim, Randolph et al. 2006). A utilização deste reagente é útil para auxiliar no rompimento de pontes de hidrogênio, pouco sensíveis à ação da pressão (St John, Carpenter et al. 2001). Para determinarmos se a presença de níveis de Gdn $\mathrm{HCl}$ relativamente baixos em combinação com alta pressão pode aumentar o rendimento de eGFP solúvel a partir de agregados, $\mathrm{Cl}$ foram submetidos à pressão na presença de até 2,0 M de Gdn $\mathrm{HCl}$. Os rendimentos de eGFP solúvel não foram melhoradas na presença de $\mathrm{Gdn} \mathrm{HCl}$ (Tabela 4), provavelmente porque a compressão na presença de $\mathrm{Gdn} \mathrm{HCl}$, apesar de promover um maior grau de dissociação dos $\mathrm{Cl}$, leva também a uma desestabilização da proteína e maior re-agregação quando ocorre a descompressão. A renaturação da proteína neste nível de pressão foi prejudicada, mesmo com níveis baixos de $\mathrm{Gdn} \mathrm{HCl}(0,5$ M), como observado por uma queda drástica na intensidade de fluorescência das amostras, o que também demonstra que a dissociação de agregados e solubilidade pode não ser indicativo do correto enovelamento proteico. 
Tabela 4. Rendimento de renaturação de eGFP em alta pressão hidrostática: 2,4 kbar (30 minutos) e 0,69 kbar (16 horas), com diferentes concentrações de Gdn HCl.

\begin{tabular}{cccc}
\hline Gdn HCl (M) & Solubilidade \% & $\begin{array}{c}\text { Fluorescência } \\
\text { Específica \% }\end{array}$ & $\begin{array}{c}\text { Rendimento Final } \\
\%\end{array}$ \\
\hline 0 & $79,1 \pm 1,76$ & $75,0 \pm 1,10$ & 59,32 \\
\hline 0,5 & $18,3 \pm 0,06$ & $0,18 \pm 0,04$ & 0,03 \\
\hline 1,0 & $41,1 \pm 0,04$ & $0,90 \pm 0,04$ & 0,36 \\
\hline 2,0 & $47,0 \pm 0,03$ & $0,88 \pm 0,01$ & 0,41 \\
\hline
\end{tabular}

Estudos recentes relataram a renaturação e a purificação de eGFP a partir de $\mathrm{Cl}$, solubilizada com uréia utilizando chaperona artificial em cromatografia de afinidade por metais imobilizados (AC-IMAC) (Dong 2009; Dong, Chen et al. 2009). Nestes artigos, a recuperação de eGFP está entre $82 \%$ e $92 \%$ e os rendimentos de fluorescência específica estão entre 80 e $95 \%$. No presente trabalho foi obtido um rendimento de recuperação de $80 \%$ de eGFP e $75 \%$ de fluorescência específica de eGFP nativa. O rendimento final de renaturação, de $60 \%$, foi muito mais elevado do que o rendimento obtido por diluição direta com uréia (14\%) (Dong, Chen et al. 2009). A concentração de eGFP utilizada no presente estudo foi de $0,4 \mathrm{mg} / \mathrm{mL}$, e os rendimentos de renaturação foram mais baixos (23\%) quando a concentração proteica foi de $1,3 \mathrm{mg} / \mathrm{mL}$ (dados não mostrados).

Com o objetivo de estudarmos a ação da temperatura de cultivo das bactérias recombinantes, de dissociação dos $\mathrm{Cl}$ sob pressão e de renaturação da eGFP, foram realizados os ensaios relatados a seguir, visando aprimorar o processo de renaturação de proteínas sob pressão.

\subsubsection{Influência da temperatura de expressão na estrutura secundária da eGFP nos $\mathrm{Cl}$}

A agregação proteica é em geral favorecida em temperaturas mais elevadas devido à forte dependência das interações hidrofóbicas envolvidas na reação de agregação (Schellman 1997). A utilização de baixas temperaturas para o cultivo de $E$. coli frequentemente afeta a distribuição das proteínas em frações 
solúvel e insolúvel, resultando em maiores rendimentos e atividade biológica de proteínas recombinantes solúveis (Scharnagl, Reif et al. 2005). Foi descrito que o estado conformacional da fração insolúvel também pode ser afetada pela temperatura de expressão das proteínas recombinantes (Vera, GonzalezMontalban et al. 2007). A proteína recombinante eGFP se acumula como $\mathrm{Cl}$ insolúveis quando as bactérias hospedeiras são cultivadas a $37^{\circ} \mathrm{C}$ ou maiores temperaturas, porém quando o cultivo é feito em temperaturas mais baixas a eGFP é produzida principalmente na forma solúvel. Com a finalidade de verificarmos se a temperatura de cultivo influencia a eGFP nos $\mathrm{Cl}$, nós produzimos esta proteína em temperaturas variando entre $37^{\circ} \mathrm{C}$ e $47^{\circ} \mathrm{C}$.

A GFP é uma proteína composta de 11 folhas- $\beta$ em forma de barril que envolvem uma $\alpha$-hélice central. Estas proteínas contêm $46 \%$ de folhas- $\beta$ e $11 \%$ de $\alpha$-helices (Ormo, Cubitt et al. 1996).

A estrutura secundária de proteínas em fase sólida pode ser estimada pela análise do espectro de vibração da banda de amida I, que se deve principalmente à vibração das pontes peptídicas e ocorre na região de $1700 \mathrm{~cm}^{-1}$ a $1600 \mathrm{~cm}^{-1}$ do espectro de infravermelho. (Byler and Susi 1986). A estrutura secundária da eGFP pura, nativa e liofilizada foi analisada pelas bandas de amida I obtidas em espectrômetro de infravermelho com transformada de Fourier. As amostras foram liofilizadas para diminuir a interferência da água na região de amida I do espectro. O espectro da eGFP nativa liofilizada na região de amida I (figura 16) mostra a presença de picos que podem ser atribuídos a elementos de estrutura secundária (Barth 2007). Estruturas desordenadas podem ser atribuídas ao pico em $1641 \mathrm{~cm}^{-}$ 1. O pico em $1654 \mathrm{~cm}^{-1}$ pode ser atribuído à a-hélices, enquanto o pico em 1666 $\mathrm{cm}^{-1}$ pode ser atribuído a estruturas em curva. Os picos em $1678 \mathrm{~cm}^{-1} \mathrm{e} 1691 \mathrm{~cm}^{-1}$ podem ser atribuídos a folhas- $\beta$ com orientação antiparalela, o que está de acordo com os dados cristalográficos sobre a GFP nativa (Ormo, Cubitt et al. 1996) e com o espectro de infravermelho da GFP selvagem (Scheyhing, Meersman et al. 2002). A comparação entre os espectros de infravermelho dos $\mathrm{Cl}$ produzidos em temperaturas variando entre $37^{\circ} \mathrm{C}$ e $47^{\circ} \mathrm{C}$ mostra que as alterações na temperatura de expressão da proteína induziram mudanças na região de amida I dos espectros. A característica mais proeminente que aparece da comparação entre os espectros é que a elevação da temperatura dos $\mathrm{Cl}$ induziu a diminuição do pico a $1628 \mathrm{~cm}^{-1}$ (folhas- $\beta$ ), o que sugere que níveis mais baixos de folhas- $\beta$ 
nativas estão presentes nos $\mathrm{Cl}$ produzidos nas temperaturas mais altas testadas $\left(42^{\circ} \mathrm{C}\right.$ e $\left.47^{\circ} \mathrm{C}\right)$. No entanto, o pico que corresponde a estruturas desordenadas $\left(1641 \mathrm{~cm}^{-1}\right)$ permanece relativamente constante. $O$ acréscimo da intensidade do pico a $1654 \mathrm{~cm}^{-1}$, de forma geral atribuído à a-hélices, que é observado para os $\mathrm{Cl}$ produzidos nas temperaturas mais altas, foi também descrito no artigo de Scheyhing e cols (Scheyhing, Meersman et al. 2002) para a desnaturação do mutante de GFP (S65A, V68L and S72A) induzida pelo aquecimento. Devido à dificuldade de discriminar os dois picos, os autores atribuíram esta elevação ao aumento da quantidade de estruturas desordenadas. No nosso caso, a resolução entre os dois picos é boa, o que sugere que a elevação da temperatura de cultivo da bactéria hospedeira possivelmente resulte em elevação de estruturas em $\alpha$ hélices nos $\mathrm{Cl}$. No entanto, não podemos descartar que o aumento deste pico se deva à elevação de outras estruturas que estejam se apresentando em uma posição fora do usual no espectro de infravermelho. Interessantemente, o pico em $1618 \mathrm{~cm}^{-1}$, característico de folhas- $\beta$ antiparalelas de agregados, é particularmente proeminente no espectro dos $\mathrm{Cl}$ produzidos a $47^{\circ} \mathrm{C}$. O pico em $1691 \mathrm{~cm}^{-1}$ da proteína nativa apresentou um desvio para comprimentos mais altos nos Cl. De modo geral, a comparação entre o espectro da eGFP nativa com os espectros referentes aos $\mathrm{Cl}$ indicam que a proteína agregada produzida na temperatura mais baixa testada $\left(37^{\circ} \mathrm{C}\right)$ apresenta um espectro mais similar ao da proteína nativa e que quanto maior a temperatura de produção mais os espectros se desviam deste padrão. 


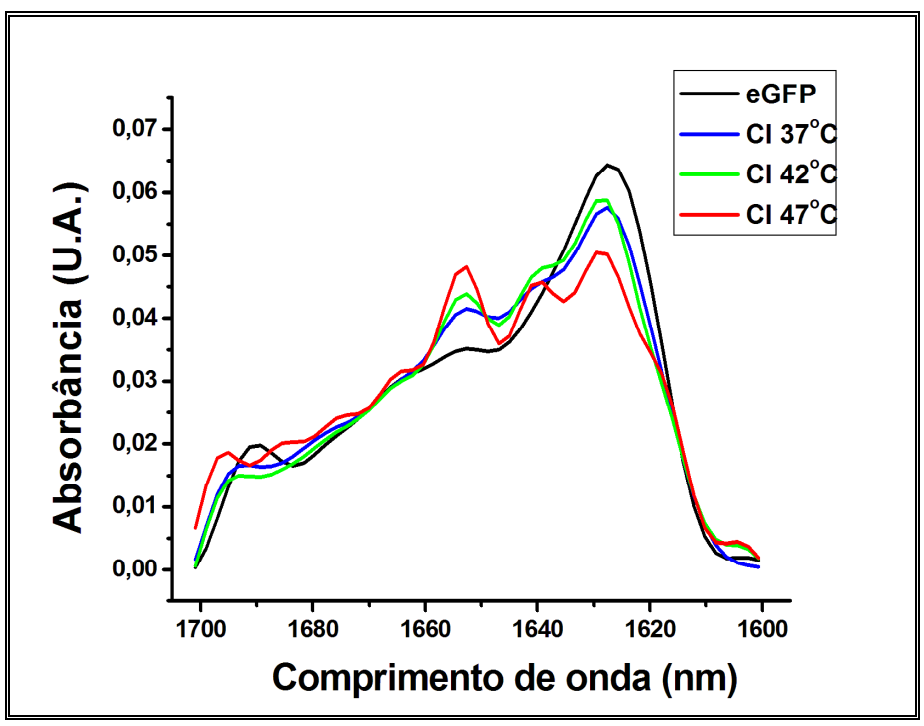

Figura 16. Espectros na região de amida I das amostras liofilizadas, eGFP nativa purificada e $\mathrm{Cl}$ produzidos em diferentes temperaturas. A área dos espectros foi uniformizada para comparação entre eles.

\subsubsection{A fluorescência dos $\mathrm{Cl}$ depende da temperatura de cultivo das bactérias}

Com a finalidade de verificarmos se a temperatura de cultivo afeta a atividade biológica das proteínas retidas nos agregados de $\mathrm{Cl}$, as bactérias $E$. coli foram cultivadas em diferentes temperaturas e os $\mathrm{Cl}$ foram extraídos. As suspensões de $\mathrm{Cl}$ de eGFP apresentam a fluorescência verde característica desta proteína, com um pico de emissão máximo em $509 \mathrm{~nm}$, indicando que existe uma certa porcentagem de proteína nativa nestas estruturas (figura 17). A fluorescência se apresentou inversamente proporcional à temperatura de cultivo da bactéria hospedeira, o que demonstra que existe uma porcentagem maior de proteína eGFP apresentando estruturas terciárias nativas nos $\mathrm{Cl}$ produzidos a $37^{\circ} \mathrm{C}$ do que nos $\mathrm{Cl}$ produzidos nas temperaturas mais elevadas. A fluorescência específica dos $\mathrm{Cl}$ produzidos a $37^{\circ} \mathrm{C}$ é 8 vezes maior do que a dos $\mathrm{Cl}$ extraídos de células cultivadas a $47^{\circ} \mathrm{C}$. Resultados similares foram obtidos em estudos utilizando a proteína recombinante Aß42-GFP (gene $A \beta 42$ relacionado ao Alzheimer em fusão com a sequência do GFP) produzido no intervalo de temperaturas de $18^{\circ} \mathrm{C}$ a $42^{\circ} \mathrm{C}$ em $\mathrm{Cl}$ (de Groot and Ventura 2006), em que a 
emissão de fluorescência dos $\mathrm{Cl}$ formados a $18^{\circ} \mathrm{C}$ foi 16 vezes maior do que aquela exibida pelos $\mathrm{Cl}$ produzidos a $42^{\circ} \mathrm{C}$.

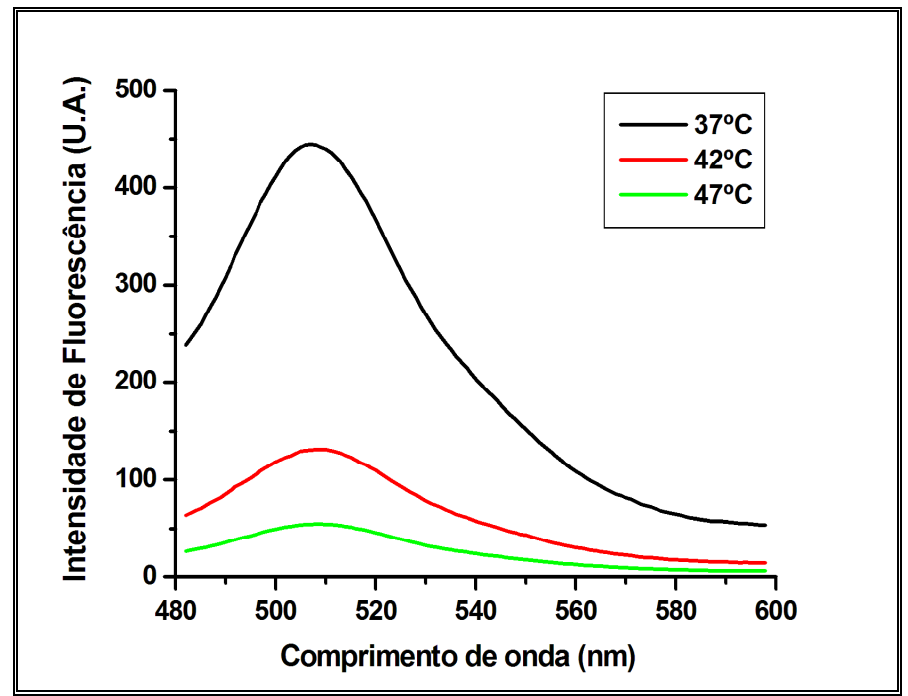

Figura 17. Intensidade de fluorescência específica de suspensões de $\mathrm{Cl}$ de eGFP produzidos em diferentes temperaturas (181 $\mathrm{gg} / \mathrm{mL}$ eGFP). Excitação em $440 \mathrm{~nm}$.

Com a finalidade de verificarmos se os $\mathrm{Cl}$ produzidos em temperaturas mais baixas seriam mais facilmente solubilizados pela ação de alta pressão, as suspensões de $\mathrm{Cl}$ expressas nas diferentes temperaturas foram submetidas a pressões crescentes, e os valores de EL foram determinados. Como podemos observar na figura 18 , a queda nos valores de $\mathrm{EL}$ dos $\mathrm{Cl}$ produzidos a $37^{\circ} \mathrm{C}$ é maior pela ação da alta pressão do que a queda de EL observada para os $\mathrm{Cl}$ produzidos a $42^{\circ} \mathrm{C}$ e $47^{\circ} \mathrm{C}$. A maior queda nos valores de $\mathrm{EL}$ para os $\mathrm{Cl}$ produzidos em menor temperatura indica que estes $\mathrm{Cl}$ são mais facilmente dissociados pela ação da pressão. É reconhecido o fato de que altas temperaturas promovem a formação de agregados mais estáveis devido ao favorecimento de interações intermoleculares à custa de contatos nativos intramoleculares e atividade proteica (Vera, Gonzalez-Montalban et al. 2007). Estes contatos estariam mais provavelmente envolvidos na formação e estabilização de estruturas de folhas- $\beta$ intermoleculares. Contrariamente, a produção de proteínas a temperaturas mais baixas resulta $\mathrm{em} \mathrm{Cl}$ mais ativos, o que indica que nestas moléculas, regiões propensas à agregação são 
provavelmente bloqueadas nos estados nativos, pois as suas cadeias laterais estariam enterradas no interior hidrofóbico ou já envolvidas na rede de contatos que estabilizam os estados proteicos nativos. Por estes motivos, a maior queda nos valores de EL para as proteínas expressas na temperatura de $37^{\circ} \mathrm{C}$ está de acordo com os resultados obtidos nas figuras 16 e 17, que demonstram maior grau de estruturas secundária e terciária para estes $\mathrm{Cl}$. Similarmente aos valores de $\mathrm{EL}$, os $\mathrm{Cl}$ produzidos a $37^{\circ} \mathrm{C}$ se apresentaram mais solúveis do que os $\mathrm{Cl}$ produzidos nas maiores temperaturas pela ação de $\mathrm{Gdn} \mathrm{HCl}$ (dados não mostrados).

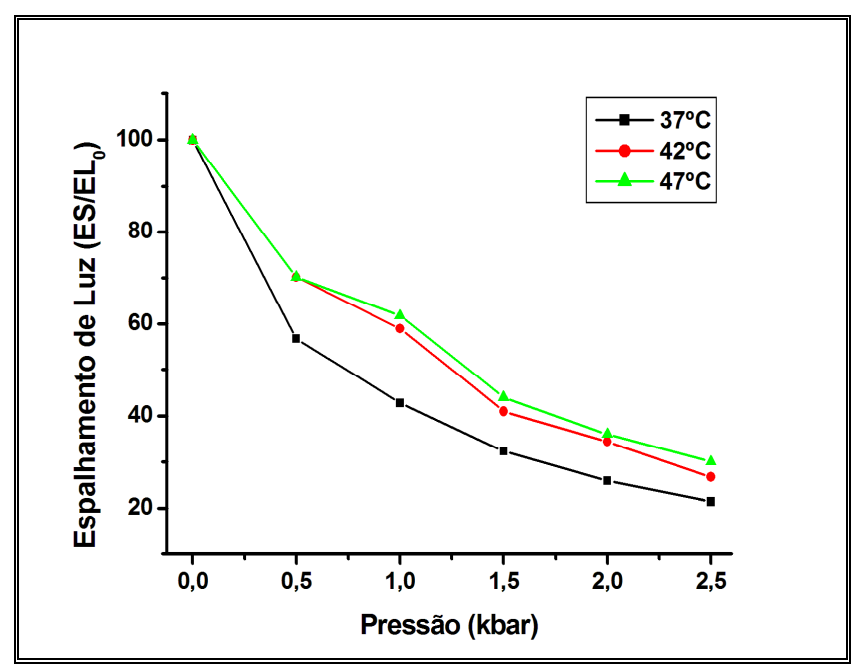

Figura 18. Dissociação de suspensões de $\mathrm{Cl}$ de eGFP pela ação de alta pressão e monitorado pelo EL. As suspensões contendo $181 \mu \mathrm{g} / \mathrm{mL}$ de eGFP foram submetidas à ação de pressões crescentes e o EL foi monitorado após 15 minutos em cada condição de pressão (excitação em $320 \mathrm{~nm}$ e emissão determinada em 315 a $325 \mathrm{~nm}$ ).

A seguir, nós investigamos se o processo de renaturação sob alta pressão poderia ser otimizado pela utilização de $\mathrm{Cl}$ em que as proteínas agregadas apresentassem estrutura conformacional mais semelhante à proteína nativa. $A$ solubilidade aumentada, o acréscimo de estruturas secundária e terciária semelhantes à da conformação nativa da eGFP nos $\mathrm{Cl}$ produzidos a $37^{\circ} \mathrm{C}$ na comparação com os $\mathrm{Cl}$ produzidos a $42^{\circ} \mathrm{C}$ e $47^{\circ} \mathrm{C}$ sugerem que maiores rendimentos de renaturação seriam obtidos quando da aplicação de alta pressão aos $\mathrm{Cl}$ expressos em baixas temperaturas, o que se confirmou (figura 19). A 
fluorescência obtida para os $\mathrm{Cl}$ produzidos a $37^{\circ} \mathrm{C}$ foi 25 vezes maior do que aquela produzida para os $\mathrm{Cl}$ produzidos a $47^{\circ} \mathrm{C}$.

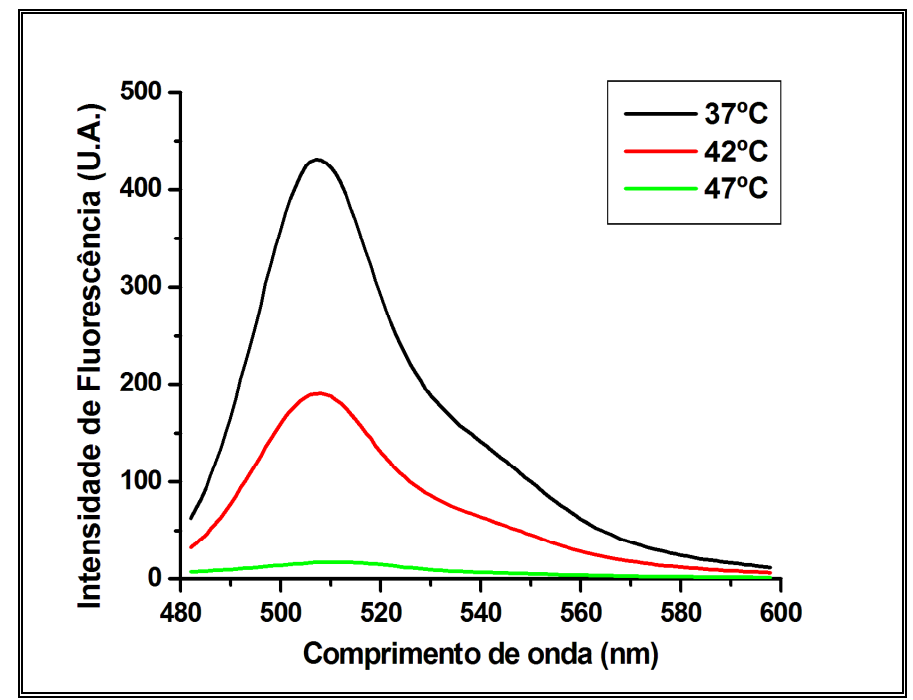

Figura 19. Intensidade de fluorescência da eGFP renaturada a partir de $\mathrm{Cl}$ produzidos em diferentes temperaturas. Suspensões contendo $181 \mu \mathrm{g} / \mathrm{mL}$ eGFP foram dissociadas pela ação de 2,4 kbar por 30 minutos e renaturadas pela incubação por 16 horas a 0,69 kbar. As suspensões foram centrifugadas e a fluorescência das frações solúveis foi monitorada (excitação $470 \mathrm{~nm}$ ).

\subsubsection{Efeito de pressão e temperatura na dissociação dos agregados e na renaturação de eGFP sob alta pressão hidrostática}

O ponto de congelamento da água é abaixado em condições de alta pressão, o que possibilita a realização de estudos dos efeitos de alta pressão a temperaturas abaixo de zero em soluções aquosas. Em baixas temperaturas a interação de aminoácidos não polares com a água é favorecida (Tsai, Maizel et al. 2002). Em temperaturas abaixo do ponto de congelamento da água o efeito hidrofóbico, que é considerado o principal fator motriz para o enovelamento de proteínas e também para interações intermoleculares que conduzem à agregação, são enfraquecidas. A desnaturação a frio é o processo no qual o estado proteico nativo perde a sua estabilidade pelo resfriamento devido à hidratação de resíduos não polares (Dias, Ala-Nissila et al. 2010).

Com o objetivo de determinarmos se o efeito da alta pressão na dissociação dos agregados poderia ser potencializada pela associação com a 
utilização de baixas temperaturas sem desnaturação proteica irreversível, a eGFP solúvel, nativa e pura foi submetida à ação de alta pressão e baixa temperatura e a fluorescência verde (a $509 \mathrm{~nm}$ ) foi monitorada. A fluorescência da eGFP apresentou um pequeno decréscimo de intensidade (7\%) quando da aplicação de 2,4 kbar e a redução da temperatura a $-9^{\circ} \mathrm{C}$ causou uma queda de mais de $46 \%$ na fluorescência. No entanto, a fluorescência retornou a $97 \%$ do valor inicial quando a temperatura foi elevada a $20^{\circ} \mathrm{C}$ e houve a descompressão para 1 bar, o que indica que o desenovelamento que ocorreu em condição de alta pressão e baixa temperatura é reversível. Este resultado está de acordo com a literatura que indica que as mudanças estruturais nas proteínas que se devem a aplicação de baixas temperaturas, bem como as que ocorrem pela elevação da pressão para níveis de até 5 kbar, são em geral reversíveis (Silva and Weber 1993) e sugere que temperaturas menores do que zero poderiam ser utilizadas juntamente com a alta pressão sem desnaturação irreversível da eGFP. O uso de baixas temperaturas $\left(-9^{\circ} \mathrm{C}\right)$ juntamente com a aplicação de alta pressão $(2,4 \mathrm{kbar})$ aos $\mathrm{Cl}$ de eGFP promoveram maior grau de dissociação, verificada pela queda no EL visível (figura 20 A) e por uma elevação de $40 \%$ na renaturação de eGFP a 0,69 kbar (figura 20 B).

Resultados similares foram obtidos na dissociação do vírus de mosaico do tabaco que ocorrem em alta pressão, também amplificado pela associação com baixas temperaturas $\left(-20^{\circ} \mathrm{C}\right)$. Assim o uso de temperaturas negativas na associação com a alta pressão pode ser uma ferramenta muito interessante para amplificar a dissociação de agregados, sem desnaturação proteica irreversível e possivelmente levando a uma elevação substancial nos rendimentos de renaturação proteica. Esta aplicação foi interessante, elevando em 11\% o rendimento de renaturação de endostatina (artigo em publicação Chura-Chambi et al. 2013). 


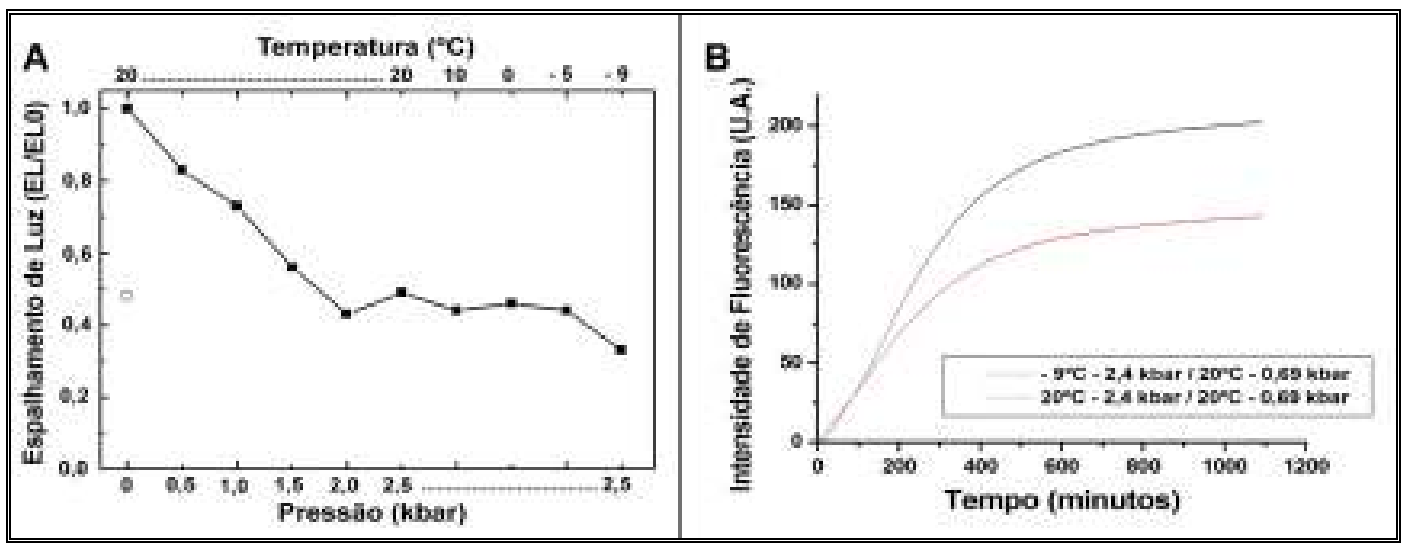

Figura 20. Efeito de alta pressão e baixa temperatura na dissociação dos $\mathrm{Cl}$ de eGFP e na renaturação da proteína. A. Leituras de EL de uma suspensão de $\mathrm{Cl}$ de eGFP. O tempo de compressão foi no mínimo 5 minutos ou até que as leituras de EL se estabilizassem (excitação em $320 \mathrm{~nm}$ e emissão 315 a $325 \mathrm{~nm}$ ); B. Renaturação de eGFP verificada pela intensidade de fluorescência a $509 \mathrm{~nm}$. A suspensão foi solubilizada pela aplicação de 2,4 kbar por 30 minutos, durante o qual a suspensão ficou por 15 minutos $a-9^{\circ} \mathrm{C}$ e mais 60 minutos a $20^{\circ} \mathrm{C}$, ou então ficou durante o mesmo tempo a $20^{\circ} \mathrm{C}$ e então a pressão foi abaixada para $0,69 \mathrm{kbar}$ e incubada nesta condição por 16 horas.

\subsubsection{Cinética de renaturação da eGFP em diferentes temperaturas sob alta pressão}

A seguir, com a finalidade de determinarmos o rendimento e a cinética de renaturação da eGFP em diferentes temperaturas variando de 10 a $50^{\circ} \mathrm{C}$ em 0,69 kbar, os $\mathrm{Cl}$ foram dissociados pela compressão de uma suspensão a 2,4 kbar por 30 minutos a $-9^{\circ} \mathrm{C}$, que se foi seguida por descompressão a 0,69 kbar nas temperaturas indicadas na figura 21. A menor intensidade de fluorescência obtida para as amostras incubadas a 35 e $50^{\circ} \mathrm{C}$ provavelmente se devem à reagregação de agregados solúveis da eGFP nestas temperaturas altas, uma indicação que é fortalecida pelo fato de que a $50^{\circ} \mathrm{C}$ o valor máximo de fluorescência adquirida foi menor do que o valor obtido pela suspensão incubada a $35^{\circ} \mathrm{C}$. De fato, os nossos dados corroboram com aqueles relatados no artigo de Fukuda e cols, onde foi demonstrado que a diminuição da renaturação de GFP selvagem devido à agregação da proteína a $35^{\circ} \mathrm{C}$ foi minimizada em temperatura mais baixa $\left(25^{\circ} \mathrm{C}\right)$ (Fukuda, Arai et al. 2000). A amostra incubada a $20^{\circ} \mathrm{C}$ foi aquela que atingiu a maior intensidade de fluorescência. $\mathrm{O}$ fato de a amostra incubada a $10^{\circ} \mathrm{C}$ ter atingido um máximo de fluorescência menor do que a amostra incubada a $20^{\circ} \mathrm{C}$ indica que na temperatura de $10^{\circ} \mathrm{C}$ seja favorecida a formação de intermediários 
de conformação não nativos. Consideramos plausível que exista uma barreira energética a ser transposta por estes intermediários de conformação para atingirem a conformação nativa, o que dificultaria o correto enovelamento para a forma nativa de menor energia livre.

O enovelamento da eGFP é um processo lento. Uma vez que o enovelamento é completado, o motivo do cromóforo (resíduos Ser 65 , Tyr 66 e Gly67) fica enterrado na hélice central da GFP. A conformação tri-dimensional da proteína presumivelmente promove o próximo passo na maturação do cromóforo, o rearranjo que resulta na ciclização do motivo tripeptídico. A seguir ocorre a oxidação e desidratação da estrutura do cromóforo, que só emite fluorescência após a finalização destas etapas (Craggs 2009). A fase lenta do processo inteiro de renaturação da GFP é a oxidação, a etapa intermediária da maturação do cromóforo e não o enovelamento da proteína em si (Reid and Flynn 1997). O cromóforo maduro permanece quimicamente intacto no estado desnaturado da GFP (Ward and Bokman 1982) e a taxa de formação de fluorescência da GFP desnaturada, mas que contém o cromóforo previamente formado e a subsequentemente renaturação é mais rápida.

Interessantemente, a figura $21 \mathrm{~B}$ mostra que a aquisição de fluorescência é iniciada por uma fase lag inicial a que se segue uma fase exponencial, similarmente ao fenômeno descrito no artigo de Reyd e Flynn para a renaturação de GFP a partir de Cl (Reid and Flynn 1997). Este fenômeno, segundo os autores, indica o início do processo sequencial de enovelamento da proteína seguido da maturação do cromóforo. Assim, esses resultados demonstram que tanto 0 enovelamento da eGFP quanto a formação do cromóforo efetivamente se iniciam na pressão de 0,69 kbar e não na pressão maior (2,4 kbar) à qual as amostras haviam sido submetidas anteriormente para dissociação dos $\mathrm{Cl}$. Experimentos similares foram também realizados em pressão de 1 bar e os resultados foram semelhantes (dados não mostrados).

O fato de a elevação na taxa de cinética de formação de fluorescência da eGFP a partir das proteínas dos $\mathrm{Cl}$, que nunca haviam sido nativas

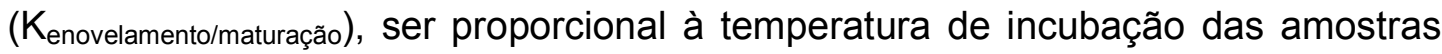
(Tabela 5) sugere ou que a taxa de enovelamento da proteína ou que a taxa de maturação do cromóforo, seja mais veloz nas temperaturas mais elevadas. 
Com a finalidade de verificarmos se a temperatura de incubação afeta o enovelamento da eGFP, a maturação do cromóforo ou as duas, amostras de eGFP nativas foram submetidas à desnaturação na temperatura de $-9^{\circ} \mathrm{C}$ em 2,4 kbar e em seguida a temperatura foi ajustada para os valores indicados (Figura 22) e a pressão foi reduzida para 0,69 kbar. Neste caso a aquisição de fluorescência se deveria à cinética de re-enovelamento da eGFP em torno do cromóforo já maduro. Como esperado, as velocidades de re-enovelamento da eGFP foram mais rápidas do que as taxas de enovelamento/maturação, pois o enovelamento não inclui a fase lenta, que é a maturação do cromóforo. $O$ reenovelamento também foi mais rápido nas temperaturas mais elevadas. A variação menor entre a cinética de re-enovelamento das amostras incubadas nas diferentes temperaturas (Figura 21 B) sugere que a maturação do cromóforo seja a etapa mais influenciada pelas variações de temperatura.

Estes experimentos mostraram que a temperatura de enovelamento é outro parâmetro que deve ser avaliado para a otimização dos processos de renaturação.

O artigo de Izuka mostra as taxas de constantes de maturação dos cromóforos de diferentes mutantes de GFP na temperatura de $37^{\circ} \mathrm{C}$ e compara estas taxas com as taxas obtidas por outros autores relatados na literatura, cujos ensaios foram realizados em diferentes temperaturas, entre $25^{\circ} \mathrm{C}$ e $37^{\circ} \mathrm{C}$ (lizuka, Yamagishi-Shirasaki et al. 2011). No entanto, os nossos resultados indicam que as taxas de maturação obtidas em diferentes temperaturas não poderiam ser comparadas devido ao fato de sofrerem grande variação com a temperatura. 

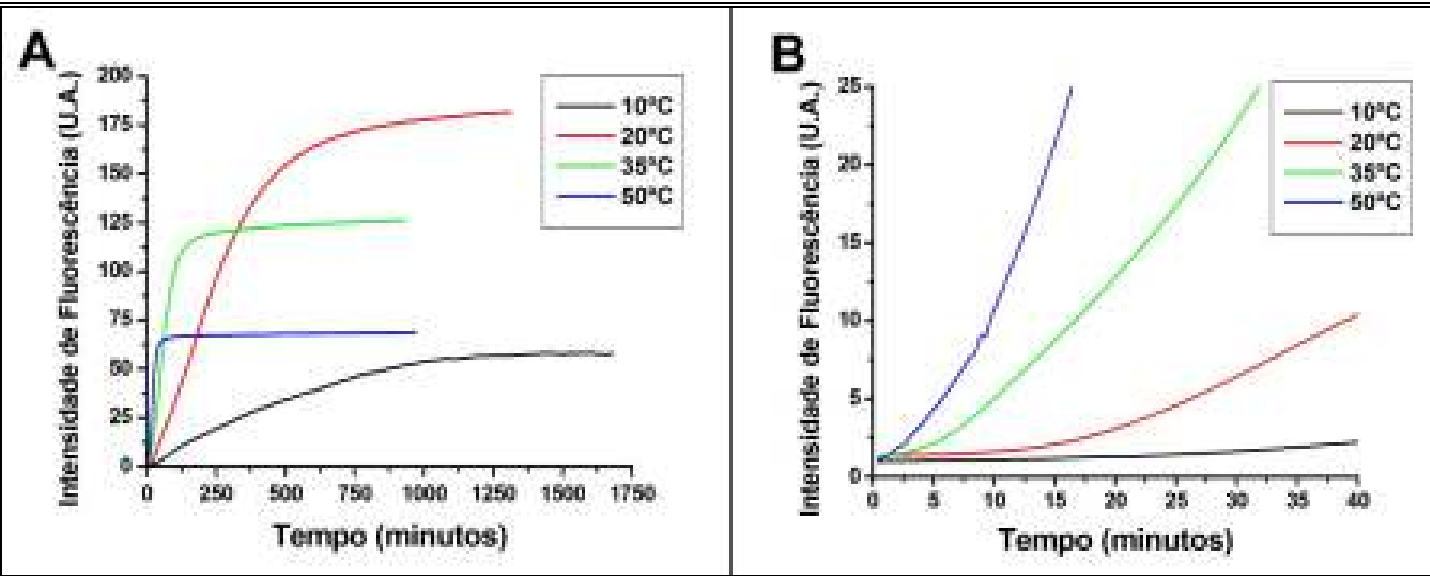

Figura 21. Cinética de renaturação da eGFP a 0,69 kbar. A suspensão de eGFP contendo 181 $\mu \mathrm{g} / \mathrm{mL}$ de eGFP foi submetida a $2,4 \mathrm{kbar}$ por 30 minutos e descompressão para 0,69 kbar e a cinética de formação de fluorescência foi monitorada a 509 nm (excitação a $470 \mathrm{~nm}$ ).

Tabela 5. Taxas de aquisição de fluorescência

\begin{tabular}{cc}
\hline & $\mathbf{K}_{\text {enovelamento/maturação }}(\mathrm{Cl})$ \\
\hline $10^{\circ} \mathrm{C}$ & $0,2546 \pm 0,00504 \times 10^{-4} \mathrm{~s}^{-1}$ \\
\hline $20^{\circ} \mathrm{C}$ & $0,4994 \pm 0,0118 \times 10^{-4} \mathrm{~s}^{-1}$ \\
\hline $35^{\circ} \mathrm{C}$ & $2,242 \pm 0,00769 \times 10^{-4} \mathrm{~s}^{-1}$ \\
\hline $50^{\circ} \mathrm{C}$ & $7,004 \pm 0,0300 \times 10^{-4} \mathrm{~s}^{-1}$ \\
\hline
\end{tabular}
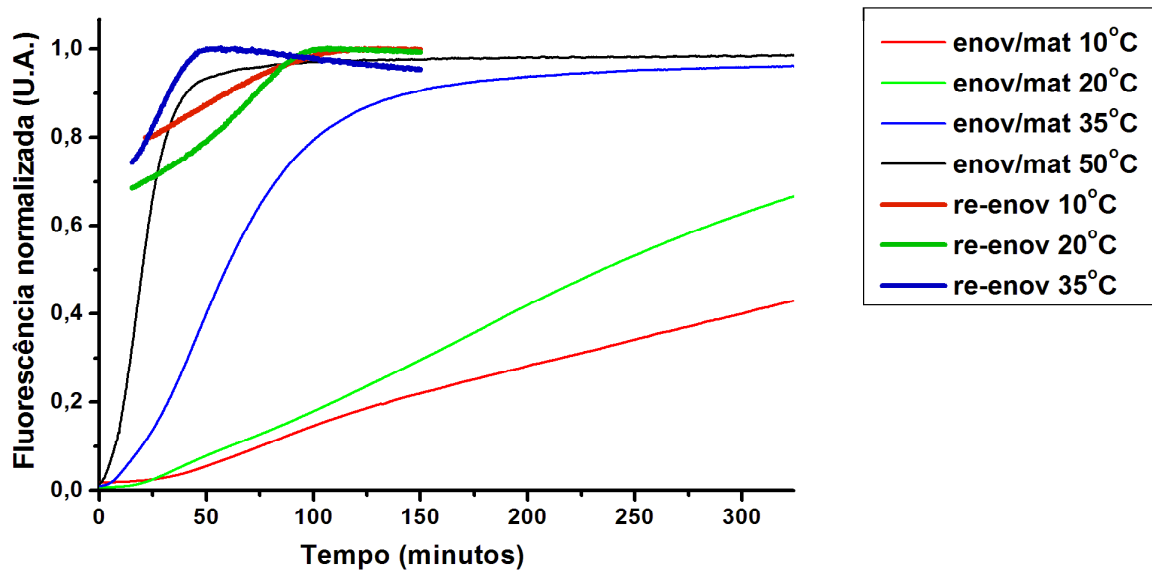

Figura 22. Cinética de fluorescência de suspensões de $\mathrm{Cl}$ e proteína nativa $(181 \mu \mathrm{g} / \mathrm{mL})$ submetidos a 2,4 kbar, despressurização para 0,69 kbar e incubação em diferentes temperaturas. 


\subsection{Proteínas de Xac}

A seguir descreveremos os resultados dos experimentos utilizando os $\mathrm{Cl}$ das proteínas de Xac.

\subsubsection{Seleção da temperatura de cultivo dos $\mathrm{Cl}$}

A expressão da proteína PilB e dos produtos dos genes XAC2810 e XAC3272, foi realizada utilizando o meio rico 2HKII para o cultivo das bactérias recombinantes, que possibilita a obtenção de alta densidade celular e também altos níveis de expressão de proteínas recombinantes (Jensen and Carlsen 1990).

Como podemos observar na figura 23 , os gráficos mostram a dissociação dos agregados em $\mathrm{Cl}$ produzidos em diferentes temperaturas, utilizando diferentes concentrações de $\mathrm{Gdn} \mathrm{HCl}$ durante 24 horas, com o objetivo de selecionar a melhor temperatura de expressão e produção de $\mathrm{Cl}$ para que os mesmos sejam mais facilmente solubilizados. Para a proteína PilB (figura 23 A), obteve-se como resultado o ponto médio de dissociação (concentração de Gdn $\mathrm{HCl}$ na qual $50 \%$ dos $\mathrm{Cl}$ foram dissociados) de $1,3 \mathrm{M}$ de $\mathrm{Gdn} \mathrm{HCl}$ para $\mathrm{Cl}$ produzidos a $20^{\circ} \mathrm{C}$, sendo que para as temperaturas mais elevadas o ponto médio aumentou para 1,7 M de Gdn HCl. Para o produto do gene XAC2810 (figura 23 B), o ponto médio de dissociação de $\mathrm{Cl}$ produzidos a $20^{\circ} \mathrm{C}$ foi $1,6 \mathrm{M}$ de $\mathrm{Gdn} \mathrm{HCl}$, e para temperaturas mais elevadas chegou a $2,5 \mathrm{M}$ de $\mathrm{Gdn} \mathrm{HCl}$. Para o produto de gene XAC3272 (figura $23 \mathrm{C}$ ), a concentração na qual $50 \%$ do $\mathrm{Cl}$ produzidos a $20^{\circ} \mathrm{C}$ foram dissociados foi de $0,5 \mathrm{M}$ de $\mathrm{Gdn} \mathrm{HCl}$, já para as temperaturas de cultivo maiores o ponto médio encontrado foi de 1,6 M de $\mathrm{Gdn} \mathrm{HCl}$. 


$$
[
$$


A seleção da temperatura de cultivo foi realizada de acordo com a concentração de $\mathrm{Gdn} \mathrm{HCl}$ menor possível para a dissociação dos Cl. Optamos pela expressão das proteínas PilB e produzidas pelos genes XAC2810 e XAC3272 na menor temperatura testada, $20^{\circ} \mathrm{C}$, tendo em vista que a expressão de $\mathrm{Cl}$ produzidos em $E$. coli cultivadas em baixas temperaturas produziu agregados mais solúveis e possivelmente com estrutura secundária mais semelhante à nativa, possibilitando um maior rendimento na obtenção de polipeptídeos ativos do que quando cultivadas em temperaturas mais altas.

\subsubsection{Efeito das diferentes proporções de glutationas reduzida/oxidada na solubilização das proteínas}

A solubilização dos agregados insolúveis é sempre o primeiro passo dos processos de renaturação proteica. A presença de pontes dissulfeto não nativas é um dos fatores que podem dificultar a renaturação de proteínas a partir de $\mathrm{Cl}$. Quanto maior o número de pontes dissulfeto, maior deverá ser a dificuldade de renaturação de uma proteína, devido à formação de pontes intermoleculares e intramoleculares não nativas. As pontes dissulfeto das proteínas agregadas em $\mathrm{Cl}$ permanecem com cisteínas livres, pelo interior das bactérias ser um ambiente redutor. Quando os $\mathrm{Cl}$ são extraídos destas células, as cisteínas são oxidadas, formando pontes dissulfeto inter e intramoleculares não nativas. Para desagregar os $\mathrm{Cl}$ com pontes dissulfeto cruzadas, agentes oxidantes e redutores devem ser adicionados ao tampão de renaturação para facilitar a formação e dissociação destas ligações (de Marco 2009). In vitro a razão apropriada de cada um dos agentes oxidante ou redutor do par redox e sua concentração podem variar para cada proteína (St John, Carpenter et al. 2002).

As proteínas PilB e aquelas expressas pelos genes XAC2810 e XAC3272, possuem 4 cisteínas em cada monômero (62, 42,2 e 34,5 kDa, respectivamente) em sua sequência, mas ainda não foi descrita a estrutura secundária e a possível formação de pontes dissulfeto na estrutura proteica. Com a finalidade de verificar as proporções de par redox, que promovem a formação de pontes dissulfeto nativas, foram adicionadas diferentes proporções de glutationas reduzida (GSH) e 
oxidada (GSSG) e 1,5 M de $\mathrm{Gdn} \mathrm{HCl}$ a suspensões de $\mathrm{Cl}$ de PilB e dos produtos dos genes XAC2810 e XAC3272, na concentração total de 10 mM de glutationas, com a finalidade de auxiliar na solubilização dos agregados pela quebra de pontes de hidrogênio intermoleculares. As suspensões de $\mathrm{Cl}$ foram submetidas à pressão de 2,4 kbar durante 16 horas antes da completa descompressão à pressão atmosférica. Frações solúveis de todas as amostras pressurizadas foram dialisadas e analisadas por eletroforese em gel de poliacrilamida como descrito em materiais e métodos.

Como podemos visualizar na figura $24 \mathrm{~A}$ e B, colunas 10 (PilB e produto do gene XAC2810, respectivamente), foi obtido um maior rendimento de solubilização na ausência de agentes oxidante/redutor ou de $\mathrm{Gdn} \mathrm{HCl}$, tendo em vista que em quase todas as condições testadas contendo os agentes oxidante/redutor e o agente desnaturante $\mathrm{Gdn} \mathrm{HCl}$, foram obtidos baixos níveis de solubilização. A condição na qual foi obtido melhor porcentagem de solubilização da proteína produto do gene XAC3272 foi a de 9 de GSH (9 mM): 1 de GSSG (1 $\mathrm{mM}$ ) e 1,5M de $\mathrm{Gdn} \mathrm{HCl}$ (figura $24 \mathrm{C}$, coluna 9). As condições selecionadas (colunas em cinza) foram utilizadas nos próximos experimentos realizados.

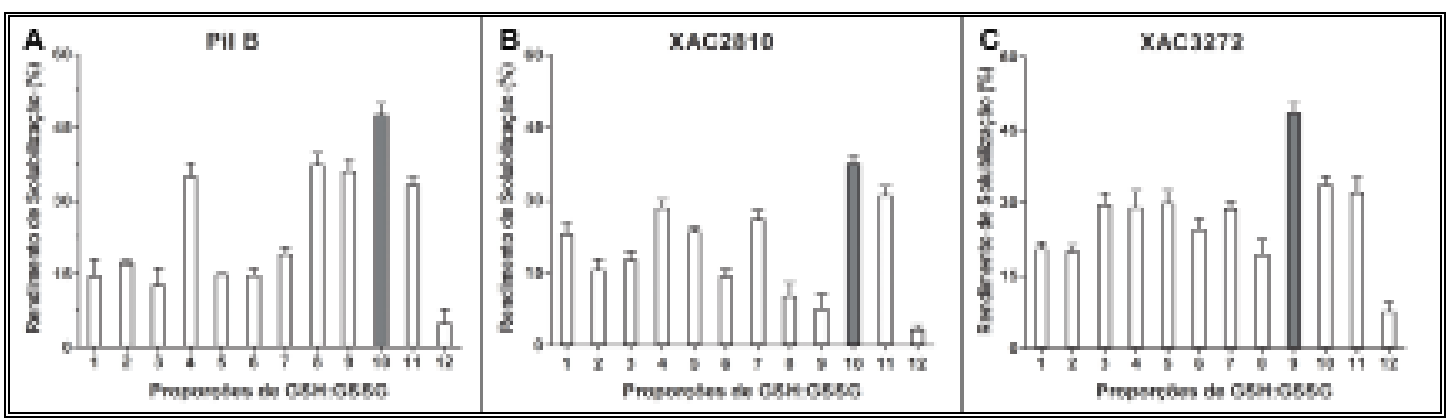

Figura 24. Rendimentos de solubilização das suspensões de $\mathrm{Cl}$ submetidas à renaturação em alta pressão. Seleção de proporção de glutationas reduzida/oxidada. A. B. e C. Tampão Tris $\mathrm{HCl} 50$ mM, pH 7,5, 1 mM EDTA e 1,5 M Gdn HCl. Colunas 1. Proporção 1:9 (GSH/GSSG); colunas 2. 1:4 (GSH/GSSG); colunas 3. 1:2 (GSH/GSSG); colunas 4. 2:3 (GSH/GSSG); colunas 5. 1:1 (GSH/GSSG); colunas 6. 3:2 (GSH/GSSG); colunas 7. 2:1 (GSH/GSSG); colunas 8. 4:1 (GSH/GSSG); colunas 9. 9:1 (GSH/GSSG); colunas 10. ausência de par redox e GdnHCl; colunas 11. ausência de par redox e colunas 12. controles que não foram submetidos à pressão. One-way ANOVA, $p<0,05$.

\subsubsection{Efeito de diferentes concentrações de $\mathrm{Gdn} \mathrm{HCl}$ na solubilização dos $\mathrm{Cl}$ sob pressão}


Durante o processo de renaturação, a solubilização da proteína de interesse pode ser obtida através da adição de altas concentrações de agentes caotrópicos como a uréia e a $\mathrm{Gdn} \mathrm{HCl}$. Foi demonstrado que pontes de hidrogênio não nativas entre moléculas nos agregados, as quais são insensíveis à aplicação de pressão, interferem com a dissolução induzida pela pressão e que a presença de $\mathrm{Gdn} \mathrm{HCl}$ ou uréia em baixas concentrações podem auxiliar a romper essas pontes e permitir a dissociação dos agregados insolúveis de forma relativamente suave (St John, Carpenter et al. 2001). Com a finalidade de se otimizar a concentração de $\mathrm{Gdn} \mathrm{HCl}$ necessária para favorecer a solubilização das proteínas estudadas, diferentes concentrações de $\mathrm{Gdn} \mathrm{HCl}$ foram adicionadas ao tampão de renaturação. Para a proteína PilB e produto do gene XAC2810 não foram adicionados agentes oxidante/redutor, tendo em vista que um rendimento mais elevado de solubilização foi obtido na ausência destes agentes (item anterior). Já para a proteína produto do gene XAC3272, além das diferentes concentrações de Gdn HCl, foi adicionada ao tampão a proporção de $9 \mathrm{mM}$ (GSH) :1 mM (GSSG) (item anterior). Suspensões de $\mathrm{Cl}$ das proteínas foram submetidas à pressão de 2,4 kbar durante 16 horas antes da descompressão completa para pressão atmosférica. Na figura 25 podemos observar que para a proteína PilB e produto do gene XAC2810 (figura 25 A e B, respectivamente, coluna 1) o maior rendimento de solubilização foi obtido em amostras na ausência de $\mathrm{Gdn} \mathrm{HCl}$, e para a proteína produto do gene XAC3272, o maior rendimento de solubilização foi aquele em que a suspensão de $\mathrm{Cl}$ foi pressurizada na presença de $1,5 \mathrm{M}$ de Gdn $\mathrm{HCl}$ (figura $25 \mathrm{C}$, coluna 4).

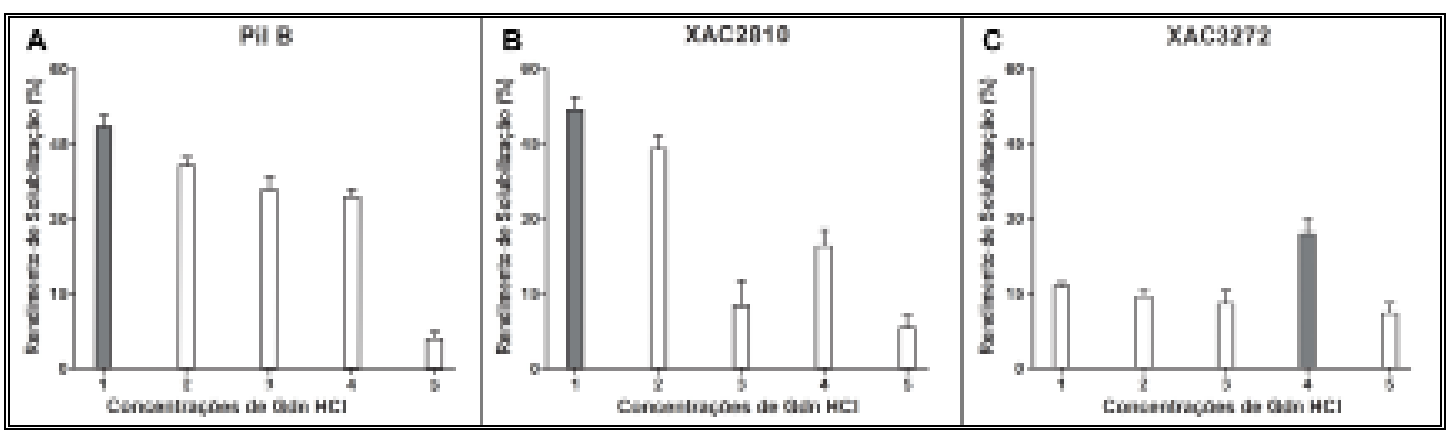

Figura 25. Rendimentos de solubilização das suspensões de $\mathrm{Cl}$ submetidas à renaturação em alta pressão. Seleção de proporção das concentrações de $\mathrm{Gnd} \mathrm{HCl}$. A e B. tampão Tris $\mathrm{HCl} 50 \mathrm{mM}$, pH 7,5, 1 mM EDTA; C. tampão Tris HCl 50 mM, pH 7,5, 1 mM EDTA, 9 mM GSH e 1 mM GSSH. Colunas 1. ausência $\mathrm{Gnd} \mathrm{HCl}$; colunas 2. $0,5 \mathrm{M}$ Gnd $\mathrm{HCl}$; colunas 3. $1 \mathrm{M} \mathrm{Gnd} \mathrm{HCl}$; colunas 4 . 
1,5 M Gnd HCl e colunas 5. controles que não foram submetidas a pressão. One-way ANOVA, $p$ $<0,05$.

\subsubsection{Efeito de diferentes aditivos na solubilização dos $\mathrm{Cl}$ sob pressão}

A reagregação de espécies incorretamente enoveladas é a principal causa da diminuição do rendimento de renaturação. Uma ferramenta que pode ser útil para modular a termodinâmica e a cinética das reações, fazendo com que seja suprimida a formação de agregados proteicos que ocorrem sob altas pressões hidrostáticas é a adição de baixas concentrações de compostos químicos, como agentes caotrópicos, aminoácidos, surfactantes e osmólitos (Clark 2001; Randolph, Seefeldt et al. 2002). Estes compostos podem aumentar significativamente o rendimento dos processos de solubilização e renaturação de proteínas. Sem eles, o processo de renaturação pode gerar uma variedade de moléculas enoveladas incorretamente (Tsumoto, Umetsu et al. 2003).

Estas pequenas moléculas são relativamente fáceis de serem removidas da solução e podem ser classificadas em dois grupos de acordo com sua influência no processo de renaturação, os que aumentam as ligações proteínaproteína e os supressores de agregação que agem reduzindo a associação de intermediários de conformação, sem interferir com o processo de renaturação (Tsumoto, Umetsu et al. 2003).

Os aditivos mais comumente utilizados nos processos de renaturação são: L-arginina (0,5 a $1 \mathrm{M})$, baixas concentrações de agentes caotrópicos como o Gdn $\mathrm{HCl}(0,5$ a $1,5 \mathrm{M})$ e a uréia (1 a $2 \mathrm{M}$ ) e surfactantes (como o triton X-100, SDS). Os surfactantes como triton X-100 e tween 20 minimizam as interações hidrofóbicas proteína-proteína, que podem levar à agregação. Sacarose, glicose, glicerol e polietilenoglicol (PEG) estabilizam os estados proteicos mais compactos. Sais como o NaCl elevam a força iônica do meio e sua presença pode ser favorável para o caso de proteínas que são sensíveis à baixa força iônica. Aminoácidos como a L-arginina são classificados tanto como supressores de agregação como agentes solubilizantes (Arakawa and Timasheff 1982; Tsumoto, Umetsu et al. 2004; Kim, Randolph et al. 2006). 
No entanto, não há nenhum método universal que seja eficaz para impedir a reagregação e promover a renaturação de todas as proteínas. Consequentemente pode ser útil que uma variedade de condições seja testada para identificar quais aditivos podem auxiliar na solubilização, na manutenção da solubilidade ou no enovelamento das proteínas para sua forma nativa (Cowan, Davies et al. 2008).

Para avaliar se a solubilização e a renaturação das proteínas PilB e produtos dos genes XAC2810 e XAC3272 poderiam ser otimizadas, alguns aditivos foram adicionados à suspensões contendo os $\mathrm{Cl}$ das proteínas de Xac. Nas suspensões de $\mathrm{Cl}$ de PilB e produto do gene XAC2810 foram somente adicionados os aditivos, já nas suspensões de $\mathrm{Cl}$ do gene XAC3272 além dos aditivos foi adicionado 9:1 de glutationas reduzida e oxidada (9 $\mathrm{mM} \mathrm{GSH}: 1 \mathrm{mM}$ GSSG) e 1,5 M de Gdn HCl, como descrito nos resultados anteriores. Estas suspensões foram então submetidas à pressão de 2,4 kbar durante 16 horas antes da descompressão completa para pressão atmosférica.

O efeito da presença de alguns aditivos na solubilização das proteínas de Xac pode ser visualizado na figura 26 , na qual podem ser observadas as médias dos rendimentos de solubilização.

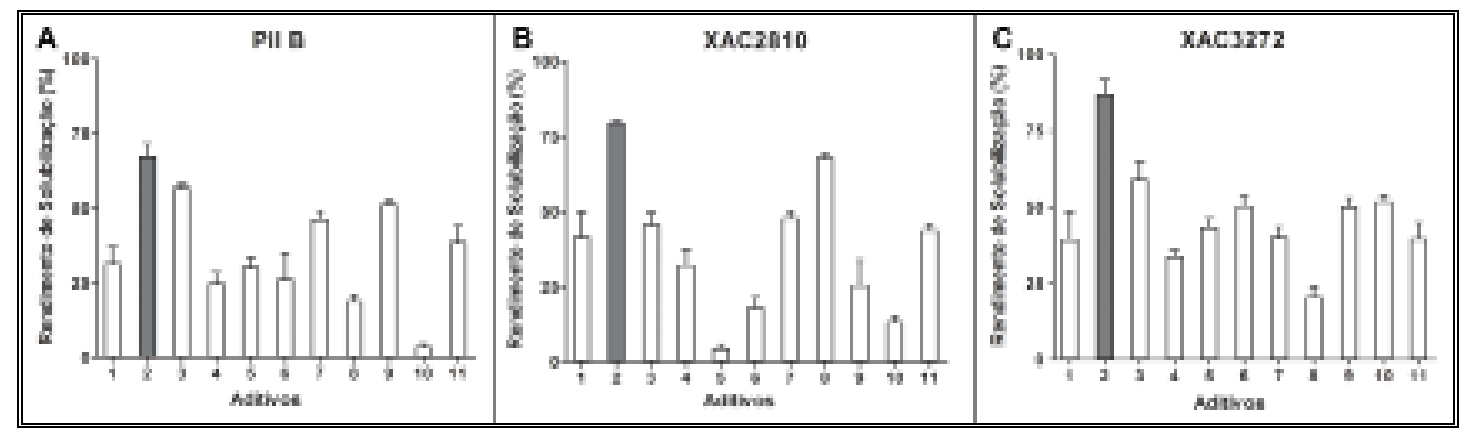

Figura 26. Rendimentos de solubilização das suspensões de $\mathrm{Cl}$ submetidas à renaturação em alta pressão. Presença de diferentes aditivos. A e B. tampão Tris $\mathrm{HCl} 50 \mathrm{mM}$, pH 7,5, 1 mM de EDTA e C. tampão Tris HCl 50 mM, pH 7,5, 1 mM de EDTA, 9 mM GSH, 1 mM GSSH e 1,5 M Gdn HCl. Colunas 1. 0,15 M de NaCl; colunas 2. 0,5 M L-Arginina; colunas 3. 0,5 M L-Arginina + 1,5 M Gdn HCl; colunas 4. $1 \mathrm{M}$ Glicose; colunas 5. $1 \mathrm{M}$ Sacarose; colunas 6. $0,1 \% \mathrm{PEG}$; colunas 7. 2,5 M Glicerol; colunas 8. $1 \mathrm{mM}$ Tween 20; colunas 9. 0,5 mM Triton; colunas 10. 5,3 mM Bis ANS (PilB), 6,2 mM Bis-ANS (XAC2810) e 7,2 mM Bis-ANS (XAC3272); colunas 11. amostras sem aditivo. One-way ANOVA, $p<0,005$. 
Observa-se na figura 26 A (proteína PilB), que a presença do aminoácido L-Arginina (coluna 2), promoveu uma elevação na porcentagem de solubilização de $38,8 \%$ para $67,4 \%$. A porcentagem de solubilização da PilB não passou de $53 \%$ na presença dos outros aditivos ou na sua ausência. Para o produto do gene XAC2810 (figura 26 B) a presença aminoácido L-Arginina praticamente dobrou o rendimento de solubilização de $43,9 \%$ para $79,7 \%$. Para o produto do gene XAC3272 (figura 26 C) houve um aumento de $39,8 \%$ para $87,3 \%$ de rendimento de solubilização na presença do aminoácido L-Arginina. O aminoácido L-Arginina se mostrou muito eficiente na solubilização proteica para as três proteínas do estudo, sendo que para todas as proteínas a porcentagem de solubilização foi maior de $67 \%$. Devido a esses resultados animadores, consideramos que a LArginina pode ser um aditivo muito interessante para a otimização de processos de renaturação induzida pela pressão. Inclusive, lembramos que foi já descrito pelo nosso grupo de pesquisa que o rendimento de renaturação da proteína OmpA70 de Leptospira interrogans induzido pela pressão foi também elevado pela adição de L-Arginina (Fraga, Chura-Chambi et al. 2010).

O aminoácido L-Arginina apresenta carga positiva, com um ponto isoelétrico elevado de 10,76 (David 2000). L-Arginina contém um grupo guanidina positivamente carregado similar ao do $\mathrm{Gdn} \mathrm{HCl}$, podendo auxiliar na solubilização dos agregados, podendo inclusive apresentar efeito mais pronunciado do que o do $\mathrm{Gdn} \mathrm{HCl} \mathrm{em} \mathrm{concentração} \mathrm{de} \mathrm{até} 2 \mathrm{M}$ (Trivedi, Raman et al. 1997; Tsumoto, Umetsu et al. 2003). Devido à eficiência na inibição da interação proteínaproteína, a L-Arginina tem sido amplamente utilizada para auxiliar na renaturação de diversas proteínas, como a lisozima (Armstrong, De Lencastre et al. 1999; Ho, Middelberg et al. 2003), caseina quinase II (Lin and Traugh 1993), neurotrofinas recombinantes humanas (Rattenholl, Lilie et al. 2001), interleucina-21 (Asano, Kudo et al. 2002), imunotoxinas recombinantes (Brinkmann, Buchner et al. 1992), fragmentos de Fab-recombinante (Buchner and Rudolph 1991) e ativadores de plaminogênio humano (Rudolph R 1990).

O mecanismo de ação do L-Arginina ainda não está claramente definido, mas de acordo com artigos publicados nos últimos 20 anos, acredita-se que o aminoácido possua três mecanismos possíveis:

1. A arginina pode interagir favoravelmente com a maioria das cadeias laterais de aminoácidos de modo a reduzir as pontes de hidrogênio, 
as interações iônicas e interações hidrofóbicas entre as proteínas (Arakawa, Ejima et al. 2007);

2. Possivelmente, o L-Arginina aumenta seletivamente a energia livre de complexos proteína-proteína e retarda as associações de proteínas, mas apresentando pouco efeito sobre a taxa de renaturação proteica (Baynes, Wang et al. 2005);

3. É provável que a arginina aumente a estabilidade e solubilidade de proteínas desnaturadas e estados intermediários, desfavorecendo a reagregação (Reddy, Lilie et al. 2005).

Este aminoácido é considerado um composto estabilizante, facilitando o correto enovelamento ao desestabilizar estruturas incorretamente enoveladas (Shiraki, Kudou et al. 2002), sendo o aminoácido mais utilizado para auxiliar a renaturação de proteínas devido ao seu eficiente papel de solubilização (Tsumoto, Umetsu et al. 2003).

\subsubsection{Efeito de diferentes métodos de compressão e descompressão na solubilização e renaturação de $\mathrm{Cl}$}

Com o objetivo de elevarmos os rendimentos de solubilização e renaturação, suspensões de $\mathrm{Cl}$ das proteínas de Xac foram submetidas a diferentes esquemas de compressão e descompressão (tabela 3).

Como podemos visualizar na figura 27 A e B, colunas 2, para a proteína PilB e produto do gene XAC2810 respectivamente, o esquema de pressão na qual foi obtido maiores rendimentos de proteínas solúveis $(87,5 \%$ e $89,6 \%$, respectivamente) foi aquele no qual a pressão de 2,4 kbar foi aplicada durante 16 horas e a descompressão foi realizada de maneira direta até a pressão atmosférica. Uma possível interpretação desses dados é a de que uma dissociação mais eficiente possa ter ocorrido durante as 16 horas de incubação a 2,4 kbar e que a renaturação dessas duas proteínas possivelmente tenha ocorrido 
em pressão atmosférica. O fato de que a renaturação tenha ocorrido em pressão atmosférica possivelmente se justifique pelo fato de que elas são, na sua forma nativa, proteínas oligoméricas, e, portanto, a associação dos monômeros seria afetada pela ação de pressão, somente sendo favorecida em baixa pressão.

Já para o produto do gene XAC3272 (figura $27 \mathrm{C}$ ), o esquema de pressão no qual foi obtido maior rendimento ( $75 \%$, coluna 4$)$, foi pela aplicação de pressão de 2,4 kbar durante 1,5 horas, despressurizando até 0,8 kbar e manutenção nesta pressão durante 16 horas antes de descompressão completa para a pressão atmosférica.

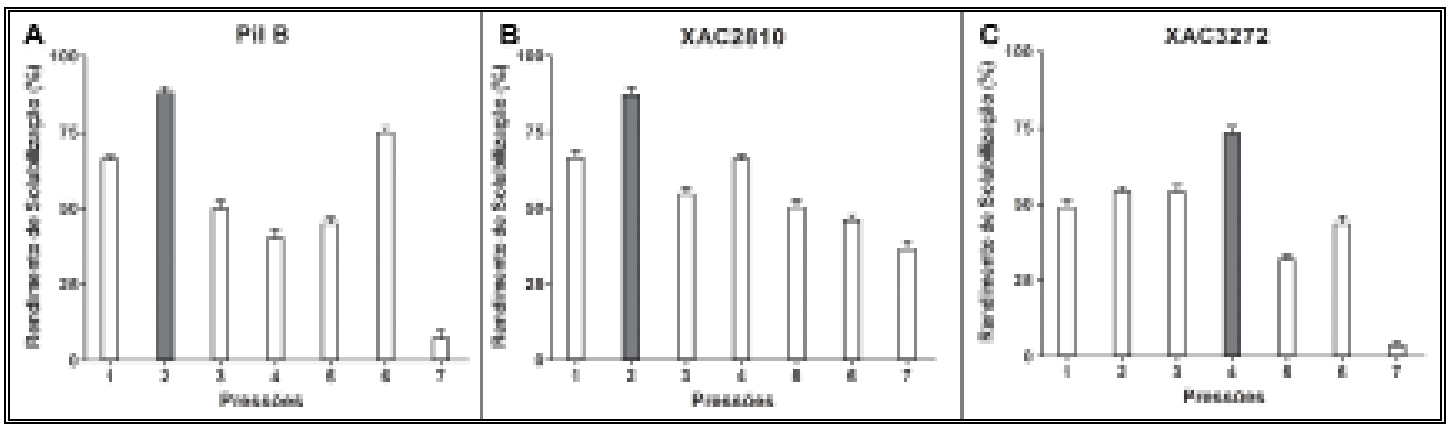

Figura 27. Rendimentos de solubilização das suspensões de $\mathrm{Cl}$ submetidas à renaturação em alta pressão. Efeito de diferentes métodos de compressão e descompressão em suspensões de $\mathrm{Cl}$ das proteínas. A e B. Tampão Tris HCl 50 mM, pH 7,5, 1 mM de EDTA e 0,5 M de L-Arginina e C. tampão Tris HCl $50 \mathrm{mM}, \mathrm{pH}$ 7,5, $1 \mathrm{mM}$ de EDTA, $9 \mathrm{mM} \mathrm{GSH}, 1 \mathrm{mM} \mathrm{GSSH}, 1,5 \mathrm{M}$ Gdn HCl e 0,5 M de L-Arginina.Colunas 1. 2,4 kbar $(1,5 \mathrm{~h})$ - descompressão direta para pressão atm (16 h); colunas 2. 2,4 kbar (16 h) - descompressão direta para pressão atm; colunas 3. 2,4 kbar (1,5 h) - descompressão em degraus até a pressão atm (16 h); colunas 4, 5 e 6. 2,4 kbar $(1,5 \mathrm{~h})$ descompressão direta para 0,8, 0,4 e 0,2 kbar, respectivamente $(16 \mathrm{~h})$ - descompressão para pressão atm; colunas 7. incubação em pressão atmosférica. One-way ANOVA, $p<0,05$.

\subsubsection{Caracterização das proteínas de Xac por cromatografia de exclusão molecular}

Tendo em vista que na análise por SDS-PAGE dos sobrenadantes das suspensões de $\mathrm{Cl}$ submetidos à alta pressão são obtidas bandas únicas que correspondem ao monômero de cada uma das três proteínas, foi realizada a 
cromatografia de exclusão molecular com a finalidade de confirmarmos a massa molecular de cada uma das três amostras.

Cada monômero da proteína PilB possui massa molecular de 62 kDa. A proteína com atividade biológica nativa de ATPase deveria se apresentar hexamérica, com massa molecular de $372 \mathrm{kDa}$. O cromatograma da figura $27 \mathrm{~A}$ de uma amostra de PilB renaturada em alta pressão e purificada em resina de afinidade por $\mathrm{Ni}^{2+}$ mostra dois picos majoritários. $\mathrm{O}$ primeiro pico apresentou um tempo de retenção de 140 minutos e o segundo pico, o tempo de retenção de 254 minutos. Pela comparação com os tempos de retenção de amostras padrão de massa molecular (figura 28 A), é possível que o pico em 140 minutos se deva ao hexâmero de PilB e que o segundo pico, com tempo de retenção de 254 minutos se deva ao monômero de PilB (62 kDa).

As figuras $28 \mathrm{~B}$ e $\mathrm{C}$, correspondem aos cromatogramas dos produtos dos genes XAC2810 e XAC3272. As duas proteínas são dímeros (84,4 kDa e 69 kDa, respectivamente). Não foram observados picos nos tempos de retenção esperados para as proteínas diméricas, nem tampouco para as formas monoméricas dessas proteínas. 


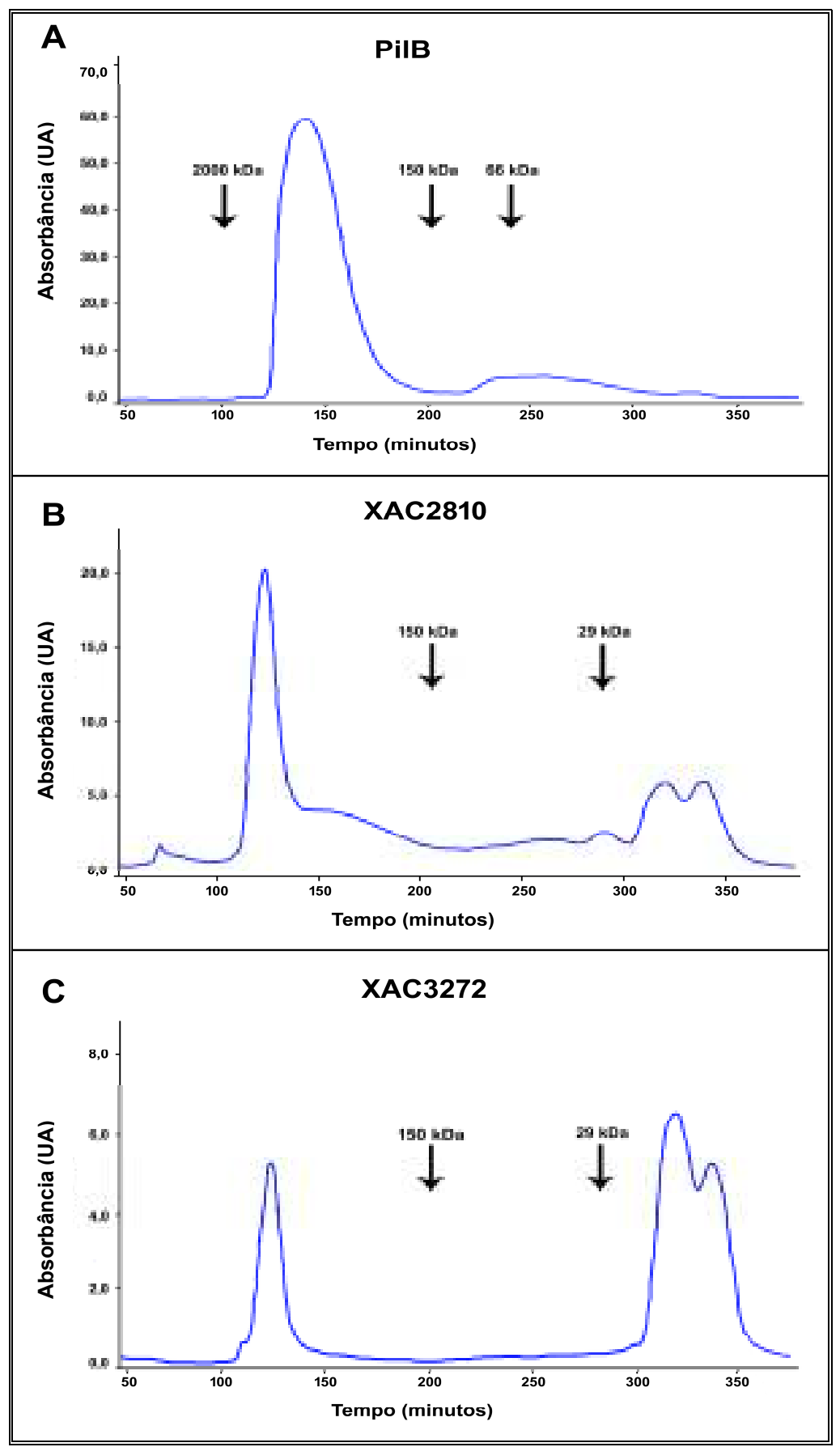

Figura 28. Cromatografia em coluna de exclusão molecular (Superdex 200) das proteínas solúveis de Xac submetidas a alta pressão hidrostática e purificadas em resina de afinidade por $\mathrm{Ni}^{2+}$. A. PilB; B. XAC2810 e C. XAC3272. As setas indicam os tempos de retanção obtidos para os padrões de massa molecular: Dextran (2000 kDa); Álcool dehidrogenase (150 kDa); Albumina (66 kDa); Anidrase Carbônica (29 kDa). 


\subsubsection{Análise de atividade biológica das proteínas de Xac renaturadas sob alta pressão hidrostática}

\subsubsection{Atividade ATPásica de PilB}

A proteína PilB renaturada sob pressão e purificada apresentou 15,5 $\pm 0,08$ $\mathrm{nmol} \mathrm{Pi} \mathrm{min}^{-1} \mathrm{mg}^{-1}$. O resultado positivo para atividade ATPásica somado ao fato de termos observado a proteína PilB com a massa molecular esperada no ensaio anterior indicam que esta proteína se apresenta na conformação nativa e biologicamente ativa e demonstra o sucesso na solubilização dos $\mathrm{Cl}$ e na renaturação da proteína PilB de Xac utilizando altas pressões hidrostáticas. Tendo em vista que a proteína PilB de Xac nunca foi antes renaturada corretamente, este é um resultado bastante relevante. Dois artigos publicados em 2008 mostraram atividade ATPásica menores do que a nossa: a PilB de Myxococcus xanthus $\left(2,9 \pm 0,6 \mathrm{nmol} \mathrm{PI} \mathrm{min}^{-1} \mathrm{mg}^{-1}\right)$ e a PilB de Pseudomonas

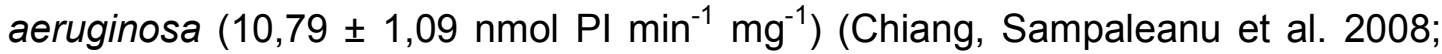
Jakovljevic, Leonardy et al. 2008).

\subsubsection{Atividade GTPásica dos produtos dos genes XAC2810 e XAC3272}

Foi realizado o ensaio de atividade GTPásica para os produtos dos genes XAC2810 e XAC3272 solubilizados sob altas pressões hidrostáticas e purificados. As proteínas não apresentaram atividade GTPásica, possivelmente pelo fato de as suas conformações estarem incorretas. No entanto, não é descartada a possibilidade de que a atividade GTPásica das enzimas diguanilato ciclases seja dependente de outras proteínas que estão envolvidas no sistema bacteriano e que estas proteínas não apresentariam esta atividade na ausência de outros componentes essenciais para sua ação (Galperin 2006). Neste caso este ensaio seria inadequado para a avaliação da renaturação das proteínas XAC2810 e XAC3272. No entanto, o resultado negativo para atividade GTPásica adicionado ao fato de não termos observado as proteínas com as massas moleculares esperadas no ensaio anterior nos desestimulam a sugerir que as proteínas 
XAC2810 e XAC3272 se apresentem na conformação nativa e biologicamente ativas. 


\section{CONCLUSÕES}

Os primeiros artigos sobre a utilização de altas pressões para propiciar a dissociação de agregados e a renaturação de proteínas agregadas foram publicados relativamente recentemente (Foguel, Robinson et al. 1999; St John, Carpenter et al. 1999; St John, Carpenter et al. 2001; St John, Carpenter et al. 2002). Alguns outros trabalhos foram descritos na literatura utilizando esta propriedade física para a dissociação de agregados e renaturação de proteínas. Os protocolos são semelhantes: utilização de tampão Tris $\mathrm{HCl}$ pH 7,5 a 8,0 contendo baixas concentrações de $\mathrm{Gdn} \mathrm{HCl}(0,5$ - 1,5 M) e aplicação de alta pressão (2 a 2,5 kbar) durante longos tempos (até 125 horas) para a dissociação e concomitante renaturação de proteínas em agregados protéicos, seguida de descompressão lenta. As temperaturas utilizadas são entre $20^{\circ} \mathrm{C}$ e $50^{\circ} \mathrm{C}$. Nos casos de proteínas contendo pontes dissulfeto, a renaturação é realizada na presença de um par óxido-redutor (glutationas oxidada e reduzida) (St John, Carpenter et al. 1999; St John, Carpenter et al. 2001; St John, Carpenter et al. 2002; Schoner, Bramlett et al. 2005; Chura-Chambi, Genova et al. 2008). A metodologia de avaliação da renaturação após aplicação de altas pressões é geralmente a quantificação de proteína na fração solúvel acompanhada em alguns casos de análise de estrutura secundária (Qoronfleh, Hesterberg et al. 2007), embora este tipo de análise não seja a ideal.

Este trabalho propôs o estudo e a otimização do processo de solubilização dos $\mathrm{Cl}$ e a renaturação da proteína eGFP, utilizando alta pressão hidrostática. A utilização da proteína fluorescente eGFP como modelo nos permitiu estudar em tempo real seu enovelamento, diferentemente de outros estudos que avaliaram tão somente a solubilidade do produto, e a partir dos conhecimentos adquiridos, propor algumas alterações nos processos de dissociação dos $\mathrm{Cl}$ e renaturação das proteínas utilizando altas pressões.

Nos estudos realizados utilizando $\mathrm{Cl}$ de eGFP, pudemos observar pela primeira vez a solubilização dos $\mathrm{Cl}$ sob altas pressões hidrostáticas, monitorados pelo espalhamento de luz e a pela microscopia eletrônica de varredura. Os resultados mostram que a dissociação dos agregados que ocorre em 2,4 kbar é irreversível, e a renaturação propriamente dita não ocorre no mesmo nível de 
pressão. A renaturação mais eficiente ocorre quando a suspensão de $\mathrm{Cl}$ é incubada em nível intermediário de pressão (0,3 a 0,7 kbar). A intensidade de fluorescência das amostras incubadas em pressão intermediária foi 136 vezes maior do que a daquelas que não foram submetidas à pressão. A quantidade de proteína solubilizada foi semelhante em amostras incubadas ou não em pressão de 0,69 kbar (pressão intermediária ótima para a renaturação da eGFP), embora a intensidade de fluorescência específica fosse maior nas amostras incubadas na pressão intermediária, o que também demonstra que o fato de que a proteína se manter solúvel não necessariamente indica que esteja na forma nativa. Mostramos ainda que houve uma maior dissociação dos $\mathrm{Cl}$ quando a alta pressão foi exercida em temperaturas negativas e um aumento de $40 \%$ na fluorescência das amostras renaturadas. Com base nesses resultados, propomos as seguintes alterações no processo de renaturação: a utilização de pressões da ordem de 2 3 kbar em temperaturas abaixo de $0^{\circ} \mathrm{C}$ para a dissociação dos $\mathrm{Cl}$ e a incubação das amostras em níveis menores de pressão (1 bar a 0,7 kbar) em temperaturas positivas para o enovelamento proteico.

Mostramos também que os $\mathrm{Cl}$ de eGFP produzidos a $37^{\circ} \mathrm{C}$ são mais facilmente solubilizados sob a ação de alta pressão do que aqueles produzidos em temperaturas mais elevadas. Os espectros de infravermelho indicaram a presença de estruturas secundárias semelhantes às da proteína nativa nos $\mathrm{Cl}$ produzidos à $37^{\circ} \mathrm{C}$ e que estas estruturas são gradativamente perdidas pela elevação de temperatura de cultivo. Além disso o fato de a fluorescência específica dos $\mathrm{Cl}$ produzidos em temperatura mais branda ser maior demonstrou que existe eGFP nativa em maior porcentagem nos $\mathrm{Cl}$ expressos em menores temperaturas. O resultado da aplicação deste estudo foi o incremento de 25 vezes no rendimento de renaturação de eGFP a partir de $\mathrm{Cl}$ produzidos em menor temperatura. Baseados nesses resultados propomos que o cultivo bacteriano seja realizado em temperaturas amenas, com maior probabilidade de os $\mathrm{Cl}$ produzidos apresentarem solubilidade aumentada e de as proteínas possuírem estruturas secundária e terciária mais semelhantes às de sua correspondente nativa e a consequente elevação dos rendimentos de obtenção de proteína nativa pela utilização de altas pressões.

Sabe-se que as forças que mantém as proteínas na sua conformação nativa/desnaturada/agregada são universais e, portanto, apesar deste trabalho ser 
especificamente um estudo sobre a renaturação da eGFP, consideramos bastante provável que as modificações propostas com base nos nossos resultados sejam úteis para elevar os rendimentos de obtenção de proteínas nativas a partir de agregados de modo geral. De fato, os nossos estudos possibilitaram 0 aprimoramento dos processos de renaturação de várias proteínas em nosso laboratório. Citamos o caso da endostatina, no qual o rendimento de $25 \%$ de renaturação obtido utilizando o processo anteriormente proposto em alta pressão (Chura-Chambi, Genova et al. 2008) foi elevado para $78 \%$ quando as condições baseadas nos conhecimentos adquiridos no presente estudo foram utilizadas (artigo em publicação Chura-Chambi et al. 2013).

Também neste trabalho descrevemos a renaturação das proteínas de Xac, PilB e a solubilização do produto dos genes XAC2810 e XAC3272, nunca antes obtidas na forma solúvel. Os rendimentos de solubilização destas três proteínas foram muito altos, entre $75 \%$ e $89 \%$. A proteína PilB mostrou alta atividade ATPásica, fato inédito para a proteína de Xac. A presença do aminoácido L-Arg se mostrou muito efetiva para elevar os rendimentos de solubilização das três proteínas de Xac. Aliás, a presença deste aminoácido tem se mostrado muito efetiva para elevar de modo substancial os rendimentos de renaturação de $80 \%$ das proteínas em estudo em nosso laboratório, o que sugere uma importante aplicabilidade deste aminoácido em associação com a utilização de altas pressões para a renaturação de proteínas a partir de agregados. 


\section{REFERÊNCIAS BIBLIOGRÁFICAS}

Ami, D., A. Natalello, et al. (2006). "Structural analysis of protein inclusion bodies by Fourier transform infrared microspectroscopy." Biochim Biophys Acta 1764(4): 793-9.

Anderson, L. S., J. (1997). "A comparison of selected mRNA and protein abundances in human liver." Electrophoresis 18: 4.

Arakawa, T., D. Ejima, et al. (2007). "Suppression of protein interactions by arginine: a proposed mechanism of the arginine effects." Biophys Chem 127(1-2): 1-8.

Arakawa, T. and S. N. Timasheff (1982). "Stabilization of protein structure by sugars." Biochemistry 21(25): 6536-44.

Armstrong, N., A. De Lencastre, et al. (1999). "A new protein folding screen: Application to the ligand binding domains of a glutamate and kainate receptor and to lysozyme and carbonic anhydrase." Protein Science 8(7): $1475-1483$.

Asano, R., T. Kudo, et al. (2002). "Antitumor activity of interleukin-21 prepared by novel refolding procedure from inclusion bodies expressed in Escherichia coli." Febs Letters 528(1-3): 70-76.

Balduino, K. N., P. J. Spencer, et al. (2011). "Refolding by high pressure of a toxin containing seven disulfide bonds: bothropstoxin-1 from Bothrops jararacussu." Mol Biotechnol 48(3): 228-34.

Baneyx, F. and M. Mujacic (2004). "Recombinant protein folding and misfolding in Escherichia coli." Nat Biotechnol 22(11): 1399-408.

Barnes, R. J. K. (1991). "An introduction to marine ecology." Ed. Oxford Blackwell Scientific Published: 351.

Barth, A. (2007). "Infrared spectroscopy of proteins." Biochimica Et Biophysica Acta-Bioenergetics 1767(9): 1073-1101.

Baynes, B. M., D. I. C. Wang, et al. (2005). "Role of arginine in the stabilization of proteins against aggregation." Biochemistry 44(12): 4919-4925.

Bebendo, I. P. I. B. F., A., Kimati, H.; Amorin, L. (1995). "Manchas foliares." Manual de Fitopatologia: Princípios e conceitos 1: 10.

Bevan, M. (2000). "Plant pathology. The bugs from Brazil." Nature 406(6792): 1401.

Bitancourt, A. A. (1957). "O Cancro Cítrico." O Biológico 23: 10.

Bokman, S. H. and W. W. Ward (1981). "Renaturation of Aequorea GreenFluorescent Protein." Biochemical and Biophysical Research Communications 101(4): 1372-1380.

Bonafe, C. F. S., J. R. V. Araujo, et al. (1994). "Intermediate States of Assembly in the Dissociation of Gastropod Hemocyanin by Hydrostatic-Pressure." Biochemistry 33(9): 2651-2660.

Boonyaratanakornkit, B. B., C. B. Park, et al. (2002). "Pressure effects on intraand intermolecular interactions within proteins." Biochim Biophys Acta 1595(1-2): 235-49.

Brinkmann, U., J. Buchner, et al. (1992). "Independent Domain Folding of Pseudomonas Exotoxin and Single-Chain Immunotoxins - Influence of Interdomain Connections." Proceedings of the National Academy of Sciences of the United States of America 89(7): 3075-3079. 
Brunings, A. M. and D. W. Gabriel (2003). "Xanthomonas citri: breaking the surface." Mol Plant Pathol 4(3): 141-57.

Buchner, J. and R. Rudolph (1991). "Renaturation, Purification and Characterization of Recombinant Fab-Fragments Produced in EscherichiaColi." Bio-Technology 9(2): 157-162.

Buttner, D. and U. Bonas (2009). "Regulation and secretion of Xanthomonas virulence factors." FEMS Microbiol Rev 34(2): 107-33.

Byler, D. M. and H. Susi (1986). "Examination of the secondary structure of proteins by deconvolved FTIR spectra." Biopolymers 25(3): 469-87.

Caballero-Herrera, A., K. Nordstrand, et al. (2005). "Effect of urea on peptide conformation in water: molecular dynamics and experimental characterization." Biophys J 89(2): 842-57.

Carrio, M. M., R. Cubarsi, et al. (2000). "Fine architecture of bacterial inclusion bodies." FEBS Lett 471(1): 7-11.

Chalfie, M. K., S. (1998). "Green Fluorescent Protein, properties, applications and protocols." Ed. Wiley-liss.

Chan, C., R. Paul, et al. (2004). "Structural basis of activity and allosteric control of diguanylate cyclase." Proc Natl Acad Sci U S A 101(49): 17084-9.

Chan, J. W. and P. H. Goodwin (1999). "The molecular genetics of virulence of Xanthomonas campestris." Biotechnol Adv 17(6): 489-508.

Chiang, P., L. M. Sampaleanu, et al. (2008). "Functional role of conserved residues in the characteristic secretion NTPase motifs of the Pseudomonas aeruginosa type IV pilus motor proteins PilB, PilT and PilU." Microbiology 154(Pt 1): 114-26.

Chura-Chambi, R. M., L. A. Genova, et al. (2008). "Refolding of endostatin from inclusion bodies using high hydrostatic pressure." Analytical Biochemistry 379(1): 32-39.

Cioni, P. and G. B. Strambini (1994). "Pressure effects on protein flexibility monomeric proteins." J Mol Biol 242(3): 291-301.

Cioni, P. and G. B. Strambini (1996). "Pressure effects on the structure of oligomeric proteins prior to subunit dissociation." J Mol Biol 263(5): 789-99.

Cioni, P. and G. B. Strambini (2002). "Tryptophan phosphorescence and pressure effects on protein structure." Biochim Biophys Acta 1595(1-2): 116-30.

Clark, E. D. (2001). "Protein refolding for industrial processes." Curr Opin Biotechnol 12(2): 202-7.

Clark, E. D. B. (1998). "Refolding of recombinant proteins." Curr Opin Biotechnol 9(2): 157-63.

Cothran, A., R. J. St John, et al. (2011). "High-pressure refolding of human vascular endothelial growth factor (VEGF) recombinantly expressed in bacterial inclusion bodies: refolding optimization, and feasibility assessment." Biotechnol Prog 27(5): 1273-81.

Cowan, R. H., R. A. Davies, et al. (2008). "A screening system for the identification of refolding conditions for a model protein kinase, p38alpha." Anal Biochem 376(1): 25-38.

Craggs, T. D. (2009). "Green fluorescent protein: structure, folding and chromophore maturation." Chemical Society Reviews 38(10): 2865-2875.

Craig, L. and J. Li (2008). "Type IV pilli: paradoxes in form and function." Current Opinion in Structural Biology 18(2): 267-277.

Craig, L., M. E. Pique, et al. (2004). "Type IV pilus structure and bacterial pathogenicity." Nature Reviews Microbiology 2(5): 363-378. 
Cubitt, A. B., R. Heim, et al. (1995). "Understanding, improving and using green fluorescent proteins." Trends Biochem Sci 20(11): 448-55.

Da Silva, A. C. e. a. (2002). "Comparison of the genomes of two Xanthomonas pathogens with differing host specificities." Nature 417: 4.

David, L. N., \& Michael, M. C. (2000). Lehninger principles of biochemistry. New York, Worth Publishers.

de Farias, F. M. C. (2009). "GFP: Uma ferramenta brilhante para a visualização da vida." Revista Virtual de Química 1(1): 6.

de Groot, N. S. and S. Ventura (2006). "Effect of temperature on protein quality in bacterial inclusion bodies." Febs Letters 580(27): 6471-6476.

de Marco, A. (2009). "Strategies for successful recombinant expression of disulfide bond-dependent proteins in Escherichia coli." Microbial Cell Factories 8.

Dias, C. L., T. Ala-Nissila, et al. (2010). "The hydrophobic effect and its role in cold denaturation." Cryobiology 60(1): 91-99.

Dill, K. A. (1990). "Dominant forces in protein folding." Biochemistry 29(31): 713355.

Dong, X. Y., L. J. Chen, et al. (2009). "Refolding and purification of histidinetagged protein by artificial chaperone-assisted metal affinity chromatography." J Chromatogr A 1216(27): 5207-13.

Dong, X. Y., Chen, L.J.; Sun, Y. (2009). "Effect of operating conditions on the refolding of

his-tagged enhanced green fluorescent protein by artificial chaperone-assisted

metal affinity chromatography." Biochem Eng J 48: 5.

Drenkard, E. and F. M. Ausubel (2002). "Pseudomonas biofilm formation and antibiotic resistance are linked to phenotypic variation." Nature 416(6882): 740-3.

Ehrmann, M. A., C. H. Scheyhing, et al. (2001). "In vitro stability and expression of green fluorescent protein under high pressure conditions." Lett Appl Microbiol 32(4): 230-4.

Fahnert, B. (2012). "Using folding promoting agents in recombinant protein production: a review." Methods Mol Biol 824: 3-36.

Fahnert, B., H. Lilie, et al. (2004). "Inclusion bodies: formation and utilisation." Adv Biochem Eng Biotechnol 89: 93-142.

Fischer, B., I. Sumner, et al. (1993). "Isolation, renaturation, and formation of disulfide bonds of eukaryotic proteins expressed in Escherichia coli as inclusion bodies." Biotechnol Bioeng 41(1): 3-13.

Foguel, D., C. R. Robinson, et al. (1999). "Hydrostatic pressure rescues native protein from aggregates." Biotechnol Bioeng 63(5): 552-8.

Fradkin, A. H., C. S. Boand, et al. (2010). "Recombinant Murine Growth Hormone from E. coli Inclusion Bodies: Expression, High-Pressure Solubilization and Refolding, and Characterization of Activity and Structure." Biotechnology Progress 26(3): 743-749.

Fraga, T. R., R. M. Chura-Chambi, et al. (2010). "Refolding of the recombinant protein OmpA70 from Leptospira interrogans from inclusion bodies using high hydrostatic pressure and partial characterization of its immunological properties." Journal of Biotechnology 148(2-3): 156-162.

Fukuda, H., M. Arai, et al. (2000). "Folding of green fluorescent protein and the cycle3 mutant." Biochemistry 39(39): 12025-12032. 
Galperin, M. Y. (2006). "Structural classification of bacterial response regulators: diversity of output domains and domain combinations." J Bacteriol 188(12): 4169-82.

Garcia-Fruitos, E., A. Aris, et al. (2007). "Localization of functional polypeptides in bacterial inclusion bodies." Appl Environ Microbiol 73(1): 289-94.

Gorovits, B. M. and P. M. Horowitz (1998). "High hydrostatic pressure can reverse aggregation of protein folding intermediates and facilitate acquisition of native structure." Biochemistry 37(17): 6132-5.

Gottwald, T. (2009). "Citrus Canker." Annu Rev Phytopathol.

Han, X., R. M. Kennan, et al. (2007). "Type IV fimbrial biogenesis is required for protease secretion and natural transformation in Dichelobacter nodosus." $\underline{\mathrm{J}}$ Bacteriol 189(14): 5022-33.

Hartley, D. L. and J. F. Kane (1988). "Properties of inclusion bodies from recombinant Escherichia coli." Biochem Soc Trans 16(2): 101-2.

Hasse, G. (1987). "A laranja no Brasil."

Heim, R., D. C. Prasher, et al. (1994). "Wavelength Mutations and Posttranslational Autoxidation of Green Fluorescent Protein." Proceedings of the National Academy of Sciences of the United States of America 91(26): 12501-12504.

Herberhold, H., S. Marchal, et al. (2003). "Characterization of the pressureinduced intermediate and unfolded state of red-shifted green fluorescent protein--a static and kinetic FTIR, UVIVIS and fluorescence spectroscopy study." J Mol Biol 330(5): 1153-64.

Ho, J. G. S., A. P. J. Middelberg, et al. (2003). "The likelihood of aggregation during protein renaturation can be assessed using the second virial coefficient." Protein Science 12(4): 708-716.

Hol, W. G. J. L., L.J.; Kalk, K.H. (1983). "Thehigh-resolution3-dimensional structure of bovine

liver rhodanese." Fundam Appl Toxicol 3: 6.

http://www.caripestnetwork.org.

http://www.fundecitrus.com.br.

http://www.redetec.org.br/inventabrasil/xanto.htm.

lizuka, R., M. Yamagishi-Shirasaki, et al. (2011). "Kinetic study of de novo chromophore maturation of fluorescent proteins." Anal Biochem 414(2): 173-8.

Jaenicke, R. (1991). "Protein folding: local structures, domains, subunits, and assemblies." Biochemistry 30(13): 3147-61.

Jaenicke, R. (1991). "Protein stability and molecular adaptation to extreme conditions." Eur J Biochem 202(3): 715-28.

Jakovljevic, V., S. Leonardy, et al. (2008). "PilB and PilT are ATPases acting antagonistically in type IV pilus function in Myxococcus xanthus." J Bacteriol 190(7): 2411-21.

Jensen, E. B. and S. Carlsen (1990). "Production of Recombinant Human GrowthHormone in Escherichia-Coli - Expression of Different Precursors and Physiological-Effects of Glucose, Acetate, and Salts." Biotechnology and Bioengineering 36(1): 1-11.

Jungblut, P., Wittmann-Liebold, B. (1995). "Protein analysis on a genomic scale." J. Biotechnol Amd 41: 9.

Kim, Y. S., T. W. Randolph, et al. (2006). "High-pressure studies on protein aggregates and amyloid fibrils." Methods Enzymol 413: 237-53. 
Lee, S. H., J. F. Carpenter, et al. (2006). "Effects of solutes on solubilization and refolding of proteins from inclusion bodies with high hydrostatic pressure." Protein Sci 15(2): 304-13.

Lefebvre, B. G., M. J. Gage, et al. (2004). "Maximizing recovery of native protein from aggregates by optimizing pressure treatment." Biotechnol Prog 20(2): 623-9.

Lefebvre, B. G. and A. S. Robinson (2003). "Pressure treatment of tailspike aggregates rapidly produces on-pathway folding intermediates." Biotechnol Bioeng 82(5): 595-604.

Leite JR, R. P. (1990). "Cancro Cítrico: Prevenção e Controle no Paraná." IAPAR. Circular(1): 1.

Leyns, F. D. C., M.; Swings J. G.; De Ley, , New York, v., p.308-356, . (1984). "The host range of the genus

Xanthomonas." J. Botanical Review 50: 48.

Lin, W. J. and J. A. Traugh (1993). "Renaturation of Casein Kinase-li from Recombinant Subunits Produced in Escherichia-Coli - Purification and Characterization of the Reconstituted Holoenzyme." Protein Expression and Purification 4(3): 256-264.

Liovic, M., M. Ozir, et al. (2012). "Inclusion bodies as potential vehicles for recombinant protein delivery into epithelial cells." Microb Cell Fact 11: 67.

Lowe, D. (2009). "Current situation, management and economic impact of Citrus canker in Florida." http://www.calcitrusquality.org/wp-.

Makino, Y., K. Amada, et al. (1997). "Chaperonin-mediated folding of green fluorescent protein." J Biol Chem 272(19): 12468-74.

Margreiter, G., P. Messner, et al. (2008). "Size characterization of inclusion bodies by sedimentation field-flow fractionation." J Biotechnol 138(3-4): 67-73.

Margreiter, G., M. Schwanninger, et al. (2008). "Impact of different cultivation and induction regimes on the structure of cytosolic inclusion bodies of TEM1beta-lactamase." Biotechnol J 3(9-10): 1245-55.

Mattick, J. S. (2002). "Type IV pili and twitching motility." Annu Rev Microbiol 56: 289-314.

Moreira, L. M., N. F. Almeida, Jr., et al. (2010). "Novel insights into the genomic basis of citrus canker based on the genome sequences of two strains of Xanthomonas fuscans subsp. aurantifolii." BMC Genomics 11: 238.

Mozhaev, V. V., K. Heremans, et al. (1996). "High pressure effects on protein structure and function." Proteins 24(1): 81-91.

Nahalka, J. and V. Patoprsty (2009). "Enzymatic synthesis of sialylation substrates powered by a novel polyphosphate kinase (PPK3)." Org Biomol Chem 7(9): 1778-80.

Namekata, T. R., A. C.; Cerávolo, L. C. (1996). "Avalição de novos métodos de erradicação de Cancro Cítrico." Laranja 17(1): 11.

Okai, M., J. Ohtsuka, et al. (2012). "High pressure refolding, purification, and crystallization of flavin reductase from Sulfolobus tokodaii strain 7." Protein Expr Purif 84(2): 214-8.

Ormo, M., A. B. Cubitt, et al. (1996). "Crystal structure of the Aequorea victoria green fluorescent protein." Science 273(5280): 1392-5.

Peltier, G. L. (1920). "Influence of temperature and humidity on the growth of Xanthomonas citri and its host plants and on infection and development of the disease." J. Agric. Res 20: 59. 
Peternel, S., J. Grdadolnik, et al. (2008). "Engineering inclusion bodies for non denaturing extraction of functional proteins." Microb Cell Fact 7: 34.

Pruvost, O., B. Boher, et al. (2002). "Survival of Xanthomonas axonopodis pv. citri in Leaf Lesions Under Tropical Environmental Conditions and Simulated Splash Dispersal of Inoculum." Phytopathology 92(4): 336-46.

Przybycien, T. M., J. P. Dunn, et al. (1994). "Secondary structure characterization of beta-lactamase inclusion bodies." Protein Eng 7(1): 131-6.

Qoronfleh, M. W., L. K. Hesterberg, et al. (2007). "Confronting high-throughput protein refolding using high pressure and solution screens." Protein Expression and Purification 55(2): 209-224.

Randolph, T. W., M. Seefeldt, et al. (2002). "High hydrostatic pressure as a tool to study protein aggregation and amyloidosis." Biochim Biophys Acta 1595(12): 224-34.

Rattenholl, A., H. Lilie, et al. (2001). "The pro-sequence facilitates folding of human nerve growth factor from Escherichia coli inclusion bodies." European Journal of Biochemistry 268(11): 3296-3303.

Reddy, R. C., H. Lilie, et al. (2005). "L-Arginine increases the solubility of unfolded species of hen egg white lysozyme." Protein Science 14(4): 929-935.

Reid, B. G. and G. C. Flynn (1997). "Chromophore formation in green fluorescent protein." Biochemistry 36(22): 6786-91.

Rossetti, V. (2001). "Manual ilustrado de doenças dos citros." Piracicaba: Fealq/Fundecitrus.: 1.

Rudolph R, F. S. (1990). Process for obtaining renatured proteins. 4,933,434.

Scharnagl, C., M. Reif, et al. (2005). "Stability of proteins: temperature, pressure and the role of the solvent." Biochim Biophys Acta 1749(2): 187-213.

Schellman, J. A. (1997). "Temperature, stability, and the hydrophobic interaction." Biophysical Journal 73(6): 2960-2964.

Scheyhing, C. H., F. Meersman, et al. (2002). "Temperature-pressure stability of green fluorescent protein: a Fourier transform infrared spectroscopy study." Biopolymers 65(4): 244-53.

Schoner, B. E., K. S. Bramlett, et al. (2005). "Reconstitution of functional nuclear receptor proteins using high pressure refolding." Mol Genet Metab 85(4): 318-22.

Schubert, T. S. S., X. (2003). "Bacterial Citrus Canker." Plant Pathology Circular 377.

Seefeldt, M. B., J. Ouyang, et al. (2004). "High-pressure refolding of bikunin: efficacy and thermodynamics." Protein Sci 13(10): 2639-50.

Shimomura, O., F. H. Johnson, et al. (1962). "Extraction, Purification and Properties of Aequorin, a Bioluminescent Protein from Luminous Hydromedusan, Aequorea." Journal of Cellular and Comparative Physiology 59(3): 223-\&.

Shiraki, K., M. Kudou, et al. (2002). "Biophysical effect of amino acids on the prevention of protein aggregation." J Biochem 132(4): 591-5.

Silva, J. L., D. Foguel, et al. (2001). "Pressure provides new insights into protein folding, dynamics and structure." Trends Biochem Sci 26(10): 612-8.

Silva, J. L. and G. Weber (1993). "Pressure stability of proteins." Annu Rev Phys Chem 44: 89-113.

Simm, R., M. Morr, et al. (2004). "GGDEF and EAL domains inversely regulate cyclic di-GMP levels and transition from sessility to motility." Mol Microbiol 53(4): 1123-34. 
Singh, S. M. and A. K. Panda (2005). "Solubilization and refolding of bacterial inclusion body proteins." J Biosci Bioeng 99(4): 303-10.

St John, R. J., J. F. Carpenter, et al. (2001). "High pressure refolding of recombinant human growth hormone from insoluble aggregates - Structural transformations, kinetic barriers, and energetics." Journal of Biological Chemistry 276(50): 46856-46863.

St John, R. J., J. F. Carpenter, et al. (1999). "High pressure fosters protein refolding from aggregates at high concentrations." Proc Natl Acad Sci U S A 96(23): 13029-33.

St John, R. J., J. F. Carpenter, et al. (2002). "High-pressure refolding of disulfidecross-linked lysozyme aggregates: thermodynamics and optimization." Biotechnol Prog 18(3): 565-71.

Steinbacher, S., S. Miller, et al. (1997). "Phage P22 tailspike protein: crystal structure of the head-binding domain at 2.3 A, fully refined structure of the endorhamnosidase at $1.56 \mathrm{~A}$ resolution, and the molecular basis of $\mathrm{O}$ antigen recognition and cleavage." J Mol Biol 267(4): 865-80.

Swings, J. G. C., E.L. (1993). "Xanthomonas." London: Chapman \& Hall.

Timmer, L. W. G., J.H; Chamberlain, H.L. (2006). "Fundamentals of Citrus Canker Management." Plant Pathology Department, Florida Cooperative Extension Service, Institute of Food and Agricultural Sciences, University of Florida.

Tokatlidis, K., P. Dhurjati, et al. (1991). "High activity of inclusion bodies formed in Escherichia coli overproducing Clostridium thermocellum endoglucanase D." FEBS Lett 282(1): 205-8.

Trivedi, V. D., B. Raman, et al. (1997). "Co-refolding denatured-reduced hen egg white lysozyme with acidic and basic proteins." FEBS Lett 418(3): 363-6.

Tsai, C. J., J. V. Maizel, Jr., et al. (2002). "The hydrophobic effect: a new insight from cold denaturation and a two-state water structure." Crit Rev Biochem Mol Biol 37(2): 55-69.

Tsien, R. Y. (1998). "The green fluorescent protein." Annu Rev Biochem 67: 50944.

Tsumoto, K., M. Umetsu, et al. (2003). "Solubilization of active green fluorescent protein from insoluble particles by guanidine and arginine." Biochem Biophys Res Commun 312(4): 1383-6.

Tsumoto, K., M. Umetsu, et al. (2004). "Role of arginine in protein refolding, solubilization, and purification." Biotechnol Prog 20(5): 1301-8.

Upadhyay, A. K., A. Murmu, et al. (2012). "Kinetics of inclusion body formation and its correlation with the characteristics of protein aggregates in Escherichia coli." PLoS One 7(3): e33951.

Vauterin, L., Rademaker, J.; Swings, J. , St. Paul, v., p.677-682, 2000. (2000). "Synopsis on the taxonomy of the genus Xanthomonas." Phytopathology 90: 5.

Vauterin, L. S., J.; Kersters, K. J. (1996). "Grouping of Xanthomonas campestris pathovars by SDS-PAGE of proteins." Gen. Microbiol, Reading 137: 9.

Ventura, S. and A. Villaverde (2006). "Protein quality in bacterial inclusion bodies." Trends Biotechnol 24(4): 179-85.

Vera, A., N. Gonzalez-Montalban, et al. (2007). "The conformational quality of insoluble recombinant proteins is enhanced at low growth temperatures." Biotechnol Bioeng 96(6): 1101-6. 
Vicente, J. G. C., J.; Roberts, S, J.; Taylor, J. D. (2001). "Identification and origin of Xanthomonas campestris pv. campestris races and related pathovars." Phytopathology 91: 5 .

Vincentelli, R., S. Canaan, et al. (2004). "High-throughput automated refolding screening of inclusion bodies." Protein Sci 13(10): 2782-92.

Ward, W. W. and S. H. Bokman (1982). "Reversible Denaturation of Aequorea Green-Fluorescent Protein - Physical Separation and Characterization of the Renatured Protein." Biochemistry 21(19): 4535-4540.

Ward, W. W. and S. H. Bokman (1982). "Reversible denaturation of Aequorea green-fluorescent protein: physical separation and characterization of the renatured protein." Biochemistry 21(19): 4535-40.

Weissman, J. S., H. S. Rye, et al. (1996). "Characterization of the active intermediate of a GroEL-GroES-mediated protein folding reaction." Cell 84(3): 481-90.

Wielgus-Kutrowska, B., M. Narczyk, et al. (2007). "Folding and unfolding of a nonfluorescent mutant of green fluorescent protein." Journal of PhysicsCondensed Matter 19(28): -

Yang, F., L. G. Moss, et al. (1996). "The molecular structure of green fluorescent protein." Nat Biotechnol 14(10): 1246-51.

Zheng, H., T. Miyakawa, et al. (2013). "Expression, high-pressure refolding and purification of human leukocyte cell-derived chemotaxin 2 (LECT2)." Protein Expr Purif 88(2): 221-229. 